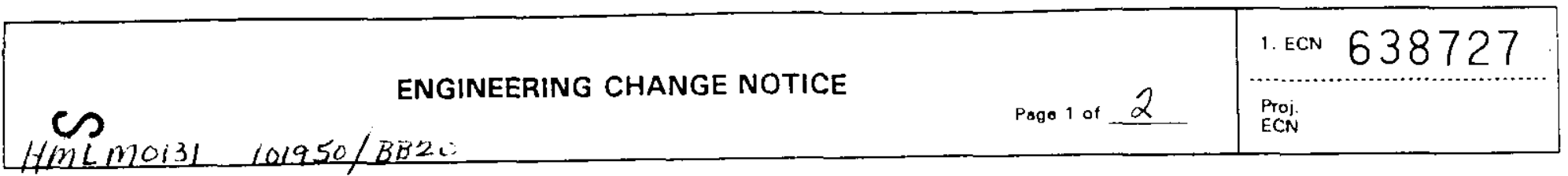

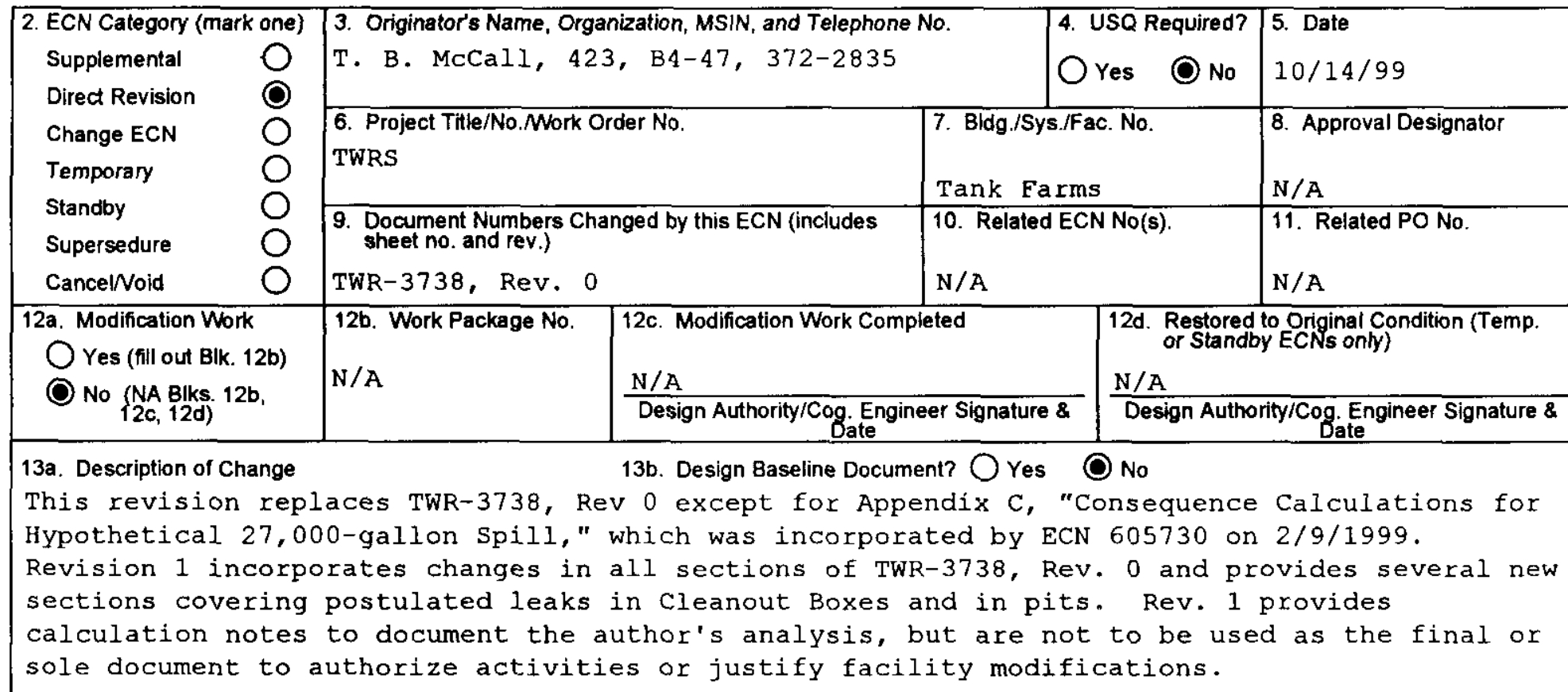

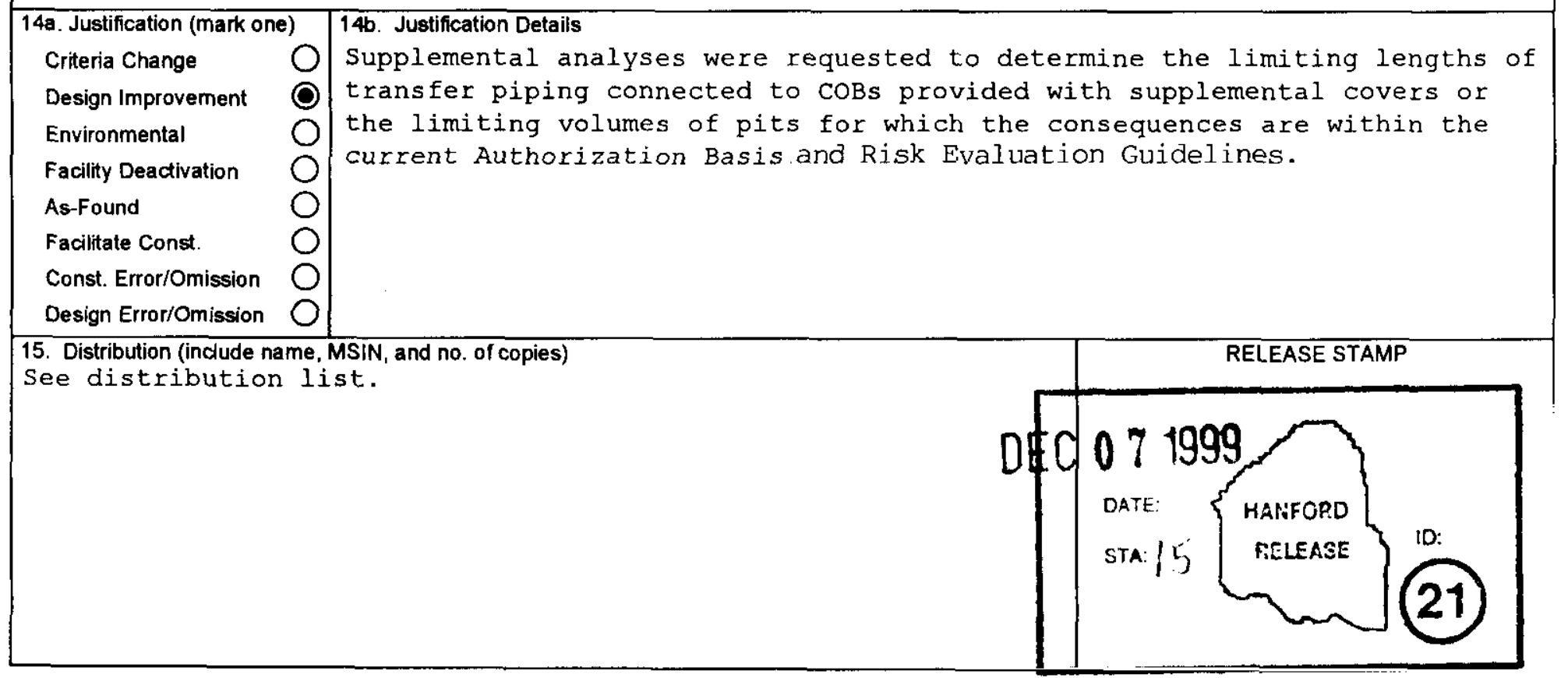




\section{ENGINEERING CHANGE NOTICE}

16. Design Verification

Required

Y Yes

(O) No
17. Cost Impact

ENGINEERING

Additional $\bigcirc \$$

Savings $O \$$
Page 2 of 2

\section{CONSTRUCTION}

Additional $\bigcirc \$$

Savings
$\$$
1. ECN (use no. from pg. 1)

638727

18. Schedule Impact (days)

Improvement

Delay

19. Change Impact Review: Indicate the related documents (other than the engineering documents identified on Side 1) that will be affected by the change described in Block 13. Enter the affected document number in Block 20.

\section{SDD/DD}

Functional Design Criteria

Operating Specification

Criticality Specification

Conceptual Design Report

Equipment Spec.

Const. Spec.

Procurement Spec.

Vendor Information

OM Manual

FSAR/SAR

Safety Equipment List

Environmental Impact Statement

Environmental Report

Environmental Permit
Radiation Work Permit

SeismiciStress Analysis
Stress/Design Report
Interface Control Drawing
Calibration Procedure
Installation Procedure
Maintenance Procedure
Engineering Procedure
Operating Instruction
Operating Procedure
Operational Safety Requirement
IEFD Drawing
Cell Arrangement Drawing
Essential Material Specification
Fac. Proc. Samp. Schedule
Inspection Plan
Inventory Adjustment Request

Tank Calibration Manual Health Physics Procedure

Spares Multiple Unit Listing

Test Procedures/Specification

Component Index

ASME Coded item

Human Factor Consideration

Computer Software

Electric Circuit Schedule

ICRS Procedure

Process Control Manual/Plan

Process Flow Chart

Purchase Requisition

Tickler File

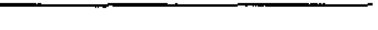

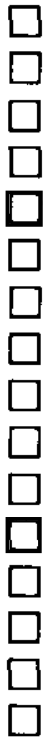

20. Other Affected Documents: (NOTE: Documents listed below will not be revised by this ECN.) Signatures below indicate that the signing organization has been notified of other affected documents listed below.

$$
\text { Document Number/Revision }
$$

Document Number/Revision

Document Number/Revision

$\mathrm{N} / \mathrm{A}$

21. Approvals

Signature

Date

Design Authority N/A

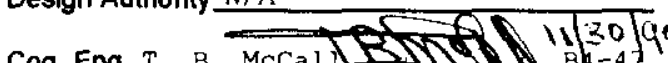

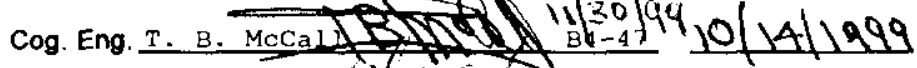

Cog. Mgr. B. E. Hey $/ 2$ B

QA N/A

Safety N/A

Environ. N/A

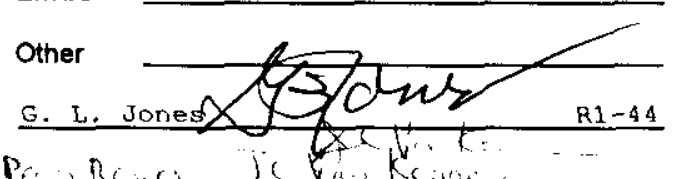

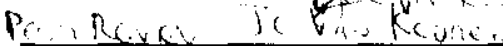
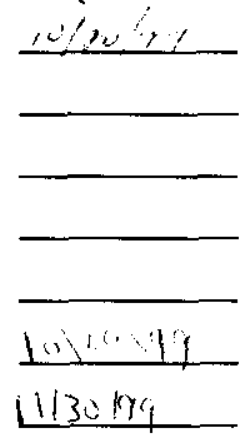

$1130 \mathrm{~kg}$
Signature

Date

Design Agent

$P E$

QA

Safety

Design

Environ.

Other

\section{DEPARTMENT OF ENERGY}

Signature or a Control Number that tracks the Approval Signature

\section{ADOITIONAL}




\section{DISTRIBUTION SHEET}

To

DE\&SH

Project Title/Work Order

Mitigated Transfer Line Leaks that Result in Surface Pools and Spray Leaks into Pits

G. W. Gault

B. E. Hey

G. L. Jones

S. N. Maruvada

T. B. McCall

G. W. Ryan

Central Files (2)

TWRS Docket Files (2)

TWRS S\&L Files (3)

TWRS DMC

tentrat Fites

DOE/RL Reading Room

From

FDNW SA \& Nuclear Engineering

Name

MSIN

$\mathrm{R} 1-44$

B4-47

$\mathrm{R} 1-44$

A.3-02

B4-47

A3-07

B1-07

$\mathrm{R} 1-44$

R1-4 4

$\mathrm{R} 1-29$

BT-07

$\mathrm{H} 2-53$
Page 1 of 1

Date $10 / 14 / 99$

EDT No. N/A

ECN No. 638727

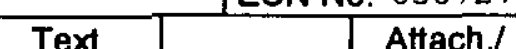

Attach.I

Appendix Only

EDT/ECN Only 


\title{
Mitigated Transfer Line Leaks that Result in Surface Pools and Spray Leaks into Pits
}

\author{
B. E. Hey and T. B. MaCall \\ Fluor Federal Services, Inc. \\ Richland, WA 99352 \\ U.S. Department of Energy Contract DE-AC06-96RL13200

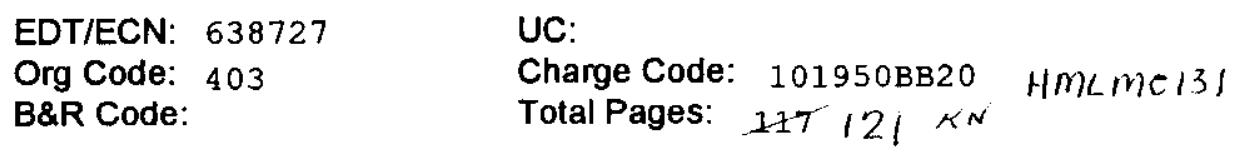 \\ Key Words: Clean-out box, leak, spill, waste transfer
}

Abstract: This analysis provides radiological and toxicological consequence calculations for postulated mitigated leaks during transfers of six waste compositions. Leaks in Cleanout Boxes equipped with supplemental covers and leaks in pits are analyzed. The limiting lengths of transfer piping connected to COBs with supplemental covers or the limiting volumes of pits are found for which the consequences are within the current Authorization Basis or Risk Evaluation Guidelines.

TRADEMARK DISCLAIMER. Reference herein to any specific commercial product, process, or service by trade name, trademark, manufacturer, or otherwise, does not necessarily constitute or imply its endorsement, recommendation, or favoring by the United States Government or any agency thereof or its contractors or subcontractors.

Printed in the United States of America. To obtain copies of this document, contact: Document Control Services, P.O. Box 950, Mailstop H6-08, Richland WA 99352, Phone (509) 372-2420; Fax (509) 376-4989.

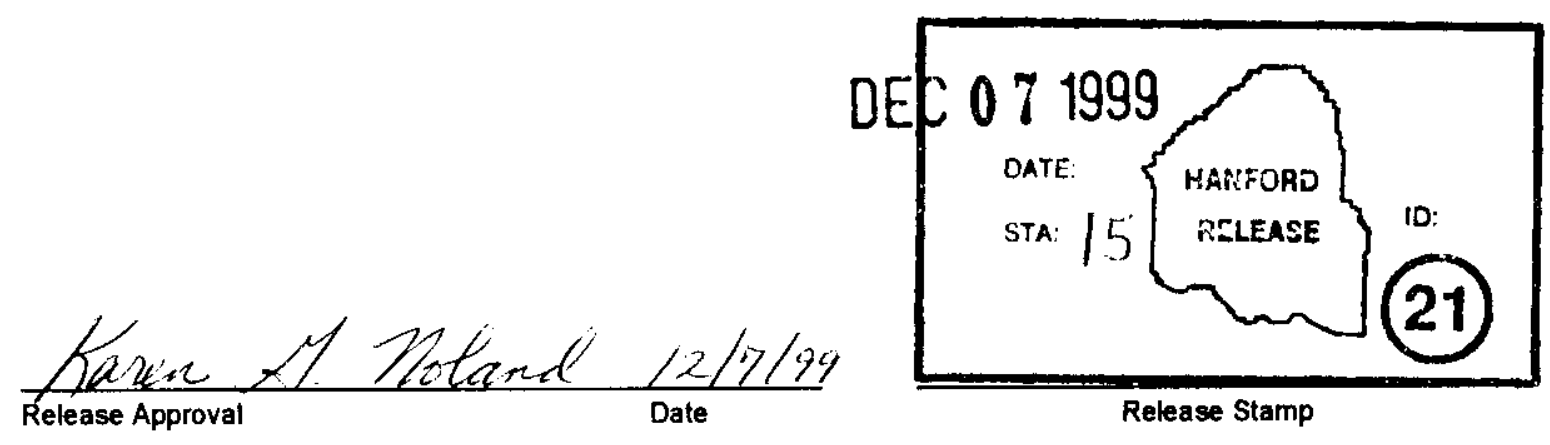

Approved For Public Release 


\section{RECORD OF REVISION}

(2) Title

Mitigated Transfer Line Leaks that Result in Surface Pools and Spray Leaks into Pits

\section{Change Control Record}

\section{(3) Revision}

0

$O A$
(4) Description of Change - Replace, Add, and Delete Pages

(7)

Initial document release via EDT \#622324

Add Appendix C (ECN 605730)

Replace entire document (ECN 638727)
Authorized for Release

\begin{tabular}{l|ll} 
(5) Cog. Engr. & (6) Cog. Mgr. Date \\
\hline
\end{tabular}

B. E. Hey D. S. Leach

D. A. Himes B. E. Hey

2/9/29 2/9/99

T. B.tSIC

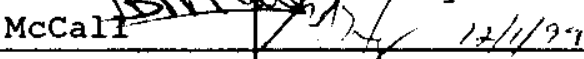


TWR-3738

REV 1

\section{MITIGATED TRANSFER LINE LEAKS THAT RESULT IN SURFACE POOLS AND SPRAY LEAKS INTO PITS}

Prepared by:

B. E. Hey, T. B. McCall

Fluor Federal Services, Inc.

Date Published

October 1999

Prepared for the U. S. Department of Energy

\section{FLUOR DANIEL

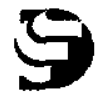 \\ HANFORD, INC. Richland, Washington}

Hanford Management and Integration Contractor for the

U.S. Department of Energy under Contract DE-AC06-96RL13200 
TWR-3738, Rev. 1

This page intentionally left blank. 


\section{TABLE OF CONTENTS}

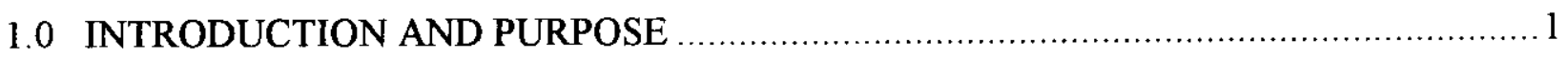

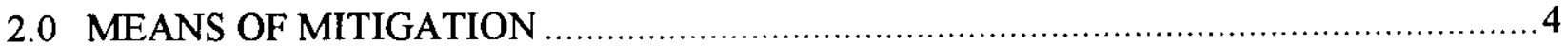

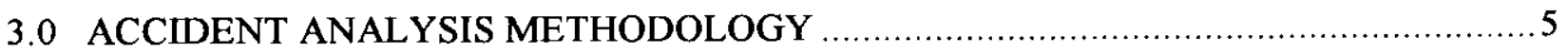

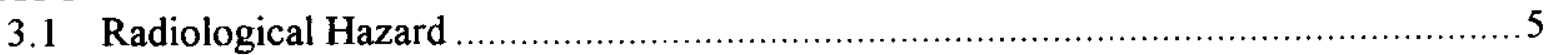

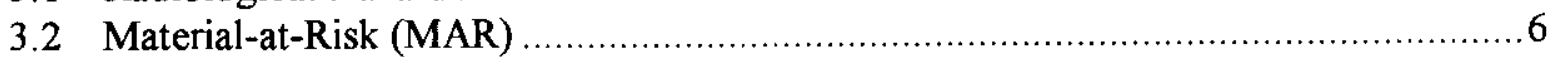

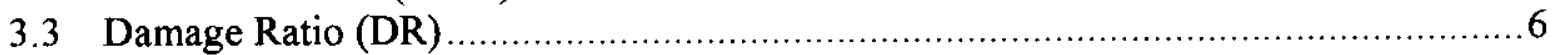

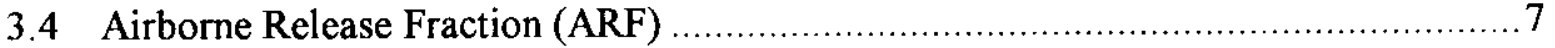

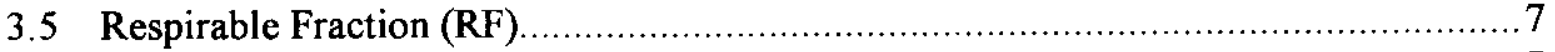

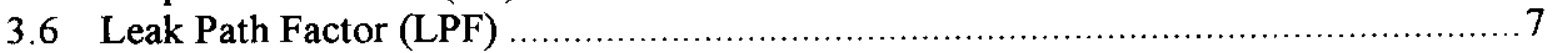

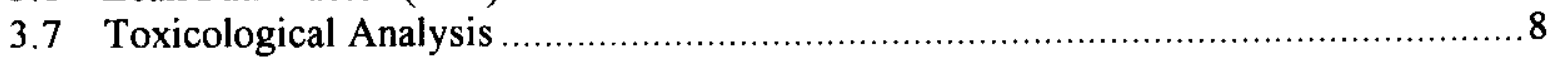

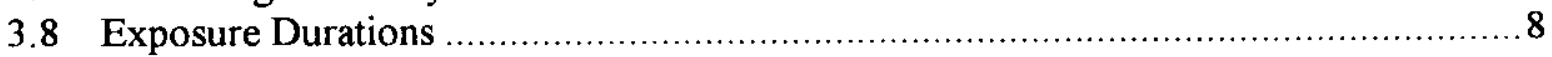

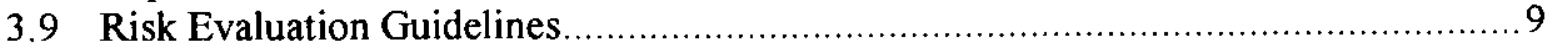

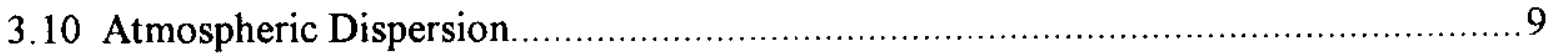

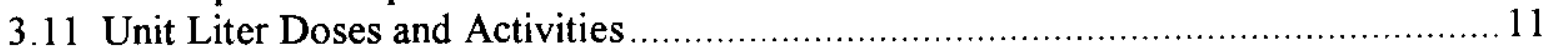

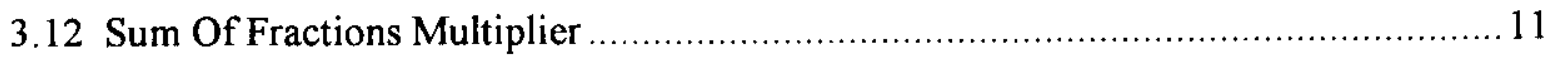

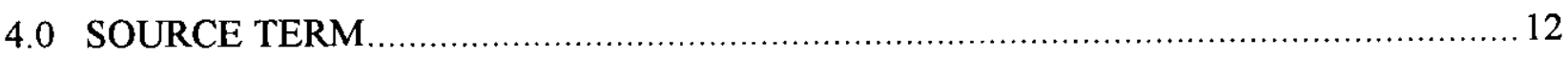

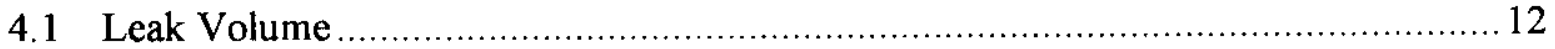

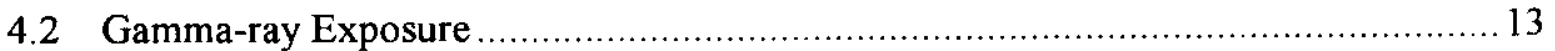

4.3 Exposure due to Inhalation of Respirable Aerosols ................................... 14

4.3.1 Aerosol Generation Due to Splashing and Splattering ........................... 14

4.3.2 Aerosol Release from Confinement .............................................. 15

4.3.2.1 Aerosol Release from Supplemental Cover ................................... 15

4.3.2.2 Aerosol Release from Pits ................................................ 16

4.3.3 Aerosol Entrainment from Waste Material Exposed to Wind....................... 18

5.0 CONSEQUENCE ANALYSIS AND CONCLUSIONS …...................................... 19

5.1 Maximum Transfer Pipe Lengths For Leaks In Cleanout Boxes........................ 19

5.1.1 Maximum Pipe Lengths for Consequences Less than in Jones (1998) ............ 19

5.1.2 Maximum Pipe Lengths for Consequences Less than REGs ...................... 22

5.2 Maximum Volumes For Leaks In Pits ..................................................... 23

5.2.1 Maximum Pit Volumes for AWF Waste Leak Consequences

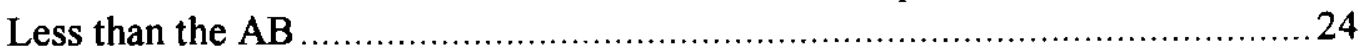

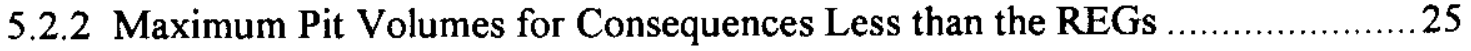

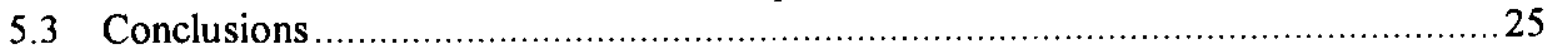

5.3.1 Leaks in Cleanout Boxes that form a Surface Pool .................................. 26

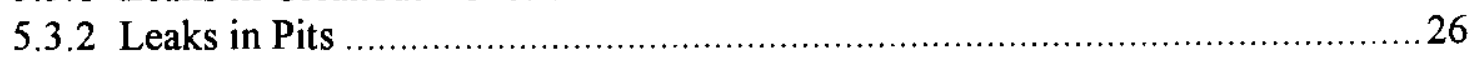

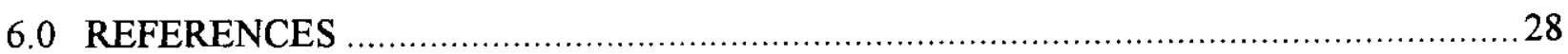

APPENDIX A - CALCULATION OF VOLUMETRIC AIR EXCHANGE
RATE FOR COB $\ldots \ldots \ldots \ldots \ldots \ldots \ldots \ldots \ldots \ldots \ldots \ldots \ldots \ldots \ldots \ldots \ldots \ldots \ldots \ldots \ldots \ldots \ldots \ldots \ldots \ldots \ldots \ldots \ldots \ldots \ldots \ldots \ldots \ldots \ldots \ldots \ldots \ldots \ldots \ldots \ldots$

APPENDIX B - SPREADSHEET CONSEQUENCE CALCULATIONS ........................... B-1 
TWR-3738, Rev. 1

APPENDIX C - BASE CASE MICROSHIELD ${ }^{T M}$ AND MICROSKYSHINETM

CALCULATIONS FOR DST 95/5 WASTE SPILL

C-1

APPENDIX D - RECORD OF REVIEW, PEER REVIEW AND HEDOP REVIEW D-1

\section{LIST OF TABLES}

Table 1-1. Criteria for Accident Analysis

. .2

Table 3-1. Atmospheric Dispersion Coefficients ( $\chi / Q)$.

Table 3-2. 95\% Atmospheric Diffusion Coefficients for Use in Conservative Estimates of Acute Exposure Due to Wind Entrainment (from Hey 1999).

Table 3-3. TWRS Waste Composite Unit Liter Doses and Activity Concentrations (from Hey 1999a)

Table 3-4. Anticipated-Frequency Continuous-Release SOF Multipliers (s/L)

Table 5-1. Maximum Pipe Lengths for $20 \mathrm{gpm}$ COB Leak with Consequences within Present Authorization Basis

Table 5-2. Details of Analysis for 20 gpm AWF 67/33 Leak in Cleanout Box

Table 5-3. Maximum Pipe Lengths for $20 \mathrm{gpm}$ COB Leak Consequences within REGs. 23

Table 5-4. Maximum Pit Volumes for AWF Waste Leak Consequences Less than the Authorization Basis

Table 5-5. Maximum Pit Volumes for Consequences within REGs 
TWR-3738, Rev. 1

\section{List of Terms}

$\begin{array}{ll}\text { AB } & \text { Authorization Basis } \\ \text { ARF } & \text { Airborne Release Fraction } \\ \text { AW } & \text { Aging Waste } \\ \text { COB } & \text { Cleanout Box } \\ \text { DST } & \text { Double Shell Tanks } \\ \text { EDE } & \text { Effective Dose Equivalent } \\ \text { LPF } & \text { Leak Path Factor } \\ \text { MAR } & \text { Material at Risk } \\ \text { MEI } & \text { Maximum Exposed Individual } \\ \text { RRF } & \text { Respirable Release Fraction } \\ \text { RPP } & \text { River Protection Project } \\ \text { Sv } & \text { Sievert (unit of radiation dose) } \\ \text { SOF } & \text { Sum of Fractions } \\ \text { SSC } & \text { Structures, Systems, and Components } \\ \text { SST } & \text { Single Shell Tanks } \\ \text { TWRS } & \text { Tank Waste Remediation System } \\ \text { TSR } & \text { Technical Safety Requirement } \\ \text { ULD } & \text { Unit Liter Dose } \\ \text { WFD } & \text { Waste Feed Delivery } \\ \chi / Q & \text { Atmospheric Dispersion Coefficient (“Chi over Q") }\end{array}$

\section{List of Trademarks}

MICROSHIELD is a trademark of Grove Engineering, Inc., Rockville, Maryland.

MICROSKYSHINE is a trademark of Grove Engineering, Inc., Rockville, Maryland. 
TWR-3738, Rev. 1

This page intentionally left blank. 
TWR-3738, Rev. 1

\section{Mitigated Transfer Line Leaks that Result in Surface Pools and Spray Leaks Into Pits}

\subsection{INTRODUCTION AND PURPOSE}

This report documents the estimated mitigated consequences of waste transfer leaks inside a clean out box (COB) or other confining structure (e.g. a valve pit). The COB is fitted with a supplemental enclosure and the pit is analyzed with cover blocks in place. The postulated $20 \mathrm{gpm}$ leak is assumed to be detected by the alarm system in the COB but, due to the small volume of the COB (approximately 50 gallons or $0.2 \mathrm{~m}^{3}$ ) it quickly overflows and a surface pool forms. Even after the transfer pump is shut off, there is a potentially large volume of waste material that could drain or siphon back through a connected waste slurry transfer pipe. The analyses of leaks inside a pit use the pit volume as an input parameter.

USQD TF-97-0923 Rev. 1 determined that a USQ existed in the TWRS BIO Rev. 0 because its evaluation of potential waste transfer leaks did not conservatively bound leaks in structures having a volume of less than $15 \mathrm{~m}^{3}$ which could overflow. JCO, Justification for Continued Operation of Transfer Lines Having Structures with Less Volume Than the 241-A-A

Valve Pit, HNF-2296 (HNF1998b) was written to document the consequences of a leak within a COB and to require supplemental covers for structures having a volume less than $15 \mathrm{~m}^{3}$.

Mitigated Transfer Line Leaks that Result in Surface Pool, TWR-3738, Rev. 0, (Hey 1999) was written to address the potential for a greater drain back volume (i.e., length of connecting piping involved in the waste transfer) than was considered in HNF-2296. Transfer line structures less than $15 \mathrm{~m}^{3}$ volume but without supplemental covers have been identified. The purpose of the analysis of leaks in pits in this document is to determine the maximum size pit such that the consequences of a leak are within the current Authorization Basis.

This report is an extension of the analyses reported in Mitigated Transfer Line Leaks that Result in Surface Pool, TWR-3738, Rev. 0, (Hey 1999b). That report analyzed four kinds of waste for a postulated $20 \mathrm{gpm}$ leak at a Cleanout Box with a Supplemental Cover that prevented waste sprays directly into the atmosphere. ECN 605730 to Hey $1999 \mathrm{~b}$ provided Appendix C, Consequence Calculations for Hypothetical 27,000-gallon Spill. Appendix C of TWR-3738, Rev. OA is not included here because its methodology has been revised. However, Appendix C of TWR-3738, Rev. 0A is still applicable to the 242-A Evaporator.

The purpose of this analysis is to determine the conditions for which the radiological and toxicological consequences of a leak will be equal to or less than a set of specific limits. The first set of limits is the Radiological Risk Evaluation Guidelines (REGs) provided in Tank Waste Remediation System Final Safety Analysis Report, HNF-SD-WM-SAR-067, Revision 1, Table 3.4.1-1 (HNF-1999). A second set of limits is in the current Authorization Basis (AB) for the River Protection Project (RRP). These limits are applied to leaks resulting in surface pools and are reported in Calculation Notes for Surface Leak Resulting in Pool, TWRS FSAR Accident Analysis, WHC-SD-WM-CN-049, Rev. 0-B (Jones 1998). A third set of limits is also part of the current $\mathrm{AB}$ and applies only to spray leaks of $\mathrm{AWF}$ waste in valve pits or from overground waste 
transfer lines. The third set is provided in Table HNF-SD-WM-BIO-001 REV 1 of FSAR Transition Spray Leak Analysis, Rev. 0, HNF-5147 (Ryan 1999).

In the first set of cases for leaks postulated inside a Cleanout Box, the results define the longest length of transfer pipe that could drain back to the $\mathrm{COB}$ and not exceed the consequences in Jones 1998. A second set of cases was run to define the longest length of transfer pipe that could drain back to the COB and not exceed the Radiological Risk Evaluation Guidelines. In the cases for leaks inside pits with cover blocks, the results define the largest pit volume that would not exceed the consequences in Ryan 1999. A second set of pit leak cases was run to define the largest pit volume that would not exceed the Radiological Risk Evaluation Guidelines.

This analysis considers the following liquid/solids content (\%) and waste compositions:

$\begin{array}{lll}67 / 33 \mathrm{AWF} & 67 / 33 \mathrm{DST} & 67 / 33 \mathrm{SST} \\ 95 / 5 \text { AWF } & 95 / 5 \text { DST } & 95 / 5 \mathrm{SST}\end{array}$

Jones (1998) also evaluated this scenario for the 67/33 AWF waste, but with a shorter pipe length, hence smaller potential drain back volume. The Jones (1998) results are part of the authorization basis (AB) for waste transfers (HNF 1998b). The Radiological Risk Evaluation Guidelines (REGs), the Safety Basis in Jones (1998), and the Safety Basis in Ryan (1999) are shown below.

Table 1-1. Criteria for Accident Analysis

\begin{tabular}{|c|c|c|l|}
\hline Receptor Location & Risk Evaluation Guideline & Jones 1998 & Ryan 1999 \\
\hline Onsite Radiological & $5.0 \mathrm{E}-03 \mathrm{~Sv}$ & $5.1 \mathrm{E}-03 \mathrm{~Sv}$ & $4.1 \mathrm{E}-2 \mathrm{~Sv}$ \\
\hline Offsite Radiological & $1.0 \mathrm{E}-03 \mathrm{~Sv}$ & $6.6 \mathrm{E}-06 \mathrm{~Sv}$ & $3.7 \mathrm{E}-5 \mathrm{~Sv}$ \\
\hline Onsite Toxicological & $1.0 \mathrm{E}+00$ & $1.4 \mathrm{E}-01$ & $8.1 \mathrm{E}-2$ \\
\hline Offsite Toxicological & $1.0 \mathrm{E}+00$ & $7.5 \mathrm{E}-04$ & $4.2 \mathrm{E}-4$ \\
\hline
\end{tabular}

To show that the net consequences of a larger leak in a COB are no greater than that previously analyzed in Jones (1998) or in the REGs, justifiable yet different assumptions are made with respect to release mechanisms. The most important of these is that the splash and splatter release mechanism as previously assumed can be mitigated by a Supplemental Cover that is placed over the COB. The splash and splatter release mechanism is also effectively mitigated by the pit cover blocks. Another refinement is that the atmospheric dispersion of aerosols released from the Supplemental Cover is analyzed separately from the atmospheric dispersion of aerosols due to entrainment from the pool surface due to wind. Previously, the atmospheric dispersion coefficients used for entrainment was based on a $1 \mathrm{~m} / \mathrm{s}$ wind speed whereas the entrainment rate was based on a $5 \mathrm{~m} / \mathrm{s}$ wind speed. In addition, the dependence of the aerosol entrainment on pool diameter is taken into account. Previously, a pool diameter of $200 \mathrm{~m}$ was assumed.

With these revised methods, this analysis determines for each waste composition the length of transfer line that could completely drain through the COB within 24 hours onto the 
ground yet have consequences within the Authorization Basis or the REGs. The pit analysis determines for each waste composition the maximum pit volume that could release all its aerosol into the environment within one hour of leak initiation.

For the pit analyses, the pit cover blocks are effective in mitigating sprays, splash, and splatter in the confined volume such that there is no direct release into the environment. Instead, the aerosols generated from the aforementioned processes are assumed to be released from the pit at the quasi-equilibrium concentration of 0.1 gram per cubic meter. The aerosol is assumed to be released in one hour, so workers are exposed to the entire release.

It is important to note that currently two kinds of evaluations are used to provide a bounding analysis of mitigated waste transfer leak scenarios. One is an analysis which maximizes the unconfined spill so that the extent of gamma-ray exposure and entrainment due to wind across the pool can be assessed. The other is an analysis which maximizes the confinement volume (e.g. a valve pit) so that the extent of greater aerosol leakage can be assessed. The former analysis identifies the limiting leak quantity and associated controls while the latter analysis identifies the limiting confinement and associated controls. The COB analyses in this document addresses the situation where confinement or Supplemental Cover volume is minimal and the extent of the surface pool is maximized. The pit analyses in this document address leaks into pits. The reports Calculation Notes for Surface Leak Resulting in Pool, TWRS FSAR Accident Analysis, WHC-SD-WM-CN-049, Rev. 0 (Hall 1996a), Hall 1996b, Hall 1996c and Revised Spray Leak Calculations for Project W-058, HNF-2542, Rev. 0 (Van Keuren 1998) address large pits (e.g. $\left.75 \mathrm{~m}^{3}\right)$ for various waste compositions.

Application of this analysis to other leak scenarios requires judicious treatment. In order to avoid a misapplication, one should carefully understand the means of mitigation discussed in Section 2.0, the representative accidents discussed in Section 3.0, the limiting leak quantities into COBs (both $1 \mathrm{hr}$ and $24 \mathrm{hr}$ ) identified in Section 5.0, and the limiting pit volumes for $1 \mathrm{hr}$ and 24 hours identified in Section 5.0. As long as the scenario in question meets those conditions, the consequences reported here will be bounding.

The first accident represented here is a $20 \mathrm{gpm}$ waste transfer leak occurring within a small (50 gallon or about $7 \mathrm{ft}^{3}$ ) enclosure (viz. Cleanout Box). The COB has a Supplemental Cover, a $1.2 \mathrm{~m}^{3}$ enclosure. Leak detection is accomplished by an engineered safety feature. The leak alarm is assumed to occur essentially instantaneously. Evacuation of affected personnel is assumed to be completed one hour after leak initiation. The leak rate due to drainage of connected piping is conservatively assumed to be the same as the pumped leak rate $(20 \mathrm{gpm})$. Abatement measures are taken to prevent dry entrainment from the exposed surface of the spill.

The second accident represented here is a transfer leak occurring within a large confinement such as a valve pit. The pit has cover blocks in place. The entire pit volume is assumed to be displaced within a short time frame (i.e., $1 \mathrm{hr}$ ) into the environment at an aerosol concentration of $0.1 \mathrm{~g} / \mathrm{m}^{3}$. It is assumed that the pit confines the entire leak such that there is no surface pool. 
TWR-3738, Rev. 1

\subsection{MEANS OF MITIGATION}

This analysis provides conservative dose estimates for leaks during waste transfer operations with mitigation controls. The mitigation credited in this analysis include engineered barriers and administrative controls. Transfer operations without this mitigation may not be bounded by these results. These controls are:

- With the exception of wind induced entrainment from soil, all sources of aerosol generation (e.g., liquid spray, splatter and splashing) are confined (see Limiting Control for Operation 3.1.1, Administrative Control 5.22 in Tank Waste Remediation System Technical Safety Requirements, HNF-SD-WM-TSR-006 [HNF 1998a], and Justification for Continued Operation of Transfer Lines Having Structures with Less Volume Than the 241-A-A Valve Pit, HNF-2296 [HNF 1998b]). The confinement system attributes specifically credited are as follows:

- The outer confinement naturally "breathes" in order to equalize internal pressure with the environment but openings are limited to prevent the free flow of wind through the confinement.

- The confinement can fill up with liquids and overflow but it does not release liquids at any significant pressure.

- The geometry is such that a release of liquid waste does not result in an unconfined free-fall of liquids by more than a few inches.

- Preventative configuration controls prevent high volume leaks (i.e., $>20 \mathrm{gpm}$ ) (see Administrative Control 5.12 in HNF 1998a).

- Leak detection is credited for initiating transfer pump shutdown and evacuation of onsite personnel (see Limiting Control for Operation 3.1.3 in HNF 1998a).

- Evacuation of onsite personnel within one hour of surface spill formation is credited to limit their exposure to radiation fields and aerosol entrained from surface waste spills (see Administrative Control 5.14 in HNF 1998a).

- Dry entrainment is prevented by emergency response procedures for leakage containment and removal (see Administrative Control 5.14 in HNF 1998a).

- Transfer pump shutdown is credited for limiting the total surface waste spill volume, including drainback, to acceptable public exposure levels (see Limiting Control for Operation 3.1.3 in HNF 1998a). 


\subsection{ACCIDENT ANALYSIS METHODOLOGY}

This analysis applies accident analysis methods similar to that used in the analyses of leaks and sprays in HNF 1999, Tank Waste Remediation System Final Safety Analysis Report, and supporting Calculation Notes. The general approach used for these kinds of analyses are summarized in the following sections. Section 4.0 presents the details of analysis methodology that is specific to the cases analyzed herein.

\subsection{RADIOLOGICAL HAZARD}

The total onsite dose can include inhalation and gamma rays from shine and skyshine. The total offsite dose is the sum of inhalation and ingestion pathways. Usually the dominant exposure pathway is inhalation. For the inhalation and ingestion pathways WHC-SD-WM-SARR-016 (Van Keuren 1996a) describes the individual dose as:

$$
\begin{array}{ll}
\text { Inhalation: } & \mathrm{D}_{\text {inh }}=\mathrm{Q} \times \chi / \mathrm{Q} \times \mathrm{R} \times \mathrm{OF} \times \mathrm{ULD}_{\text {inh }} \\
\text { Ingestion: } & \mathrm{D}_{\text {ing }}=\mathrm{Q} \times \chi / \mathrm{Q} \times \mathrm{ULD}_{\text {ing }} \quad(\mathrm{Eq} .2)
\end{array}
$$

where:

$$
\begin{aligned}
& \mathrm{D}_{\text {inh }}=\text { dose due to inhalation (Sv) } \\
& D_{\text {ing }}=\text { dose due to ingestion (Sv) } \\
& \mathrm{Q}=\text { source term }(\mathrm{L}) \text {, } \\
& \chi / \mathrm{Q}=\text { atmospheric diffusion coefficient }\left(\mathrm{s} / \mathrm{m}^{3}\right) \text {, } \\
& \mathrm{R}=\text { breathing rate }\left(3.3 \mathrm{E}-04 \mathrm{~m}^{3} / \mathrm{sec} \text { for } 12 \text {-hour exposure, } 2.7 \mathrm{E}-04 \mathrm{~m}^{3} / \mathrm{sec} \text { for } 24\right. \text {-hour) } \\
& \text { (WHC-SD-WM-SARR-016 [Van Keuren 1996a], the higher breathing rate is used } \\
& \text { herein for leaks in cleanout boxes). } \\
& \mathrm{OF}=\text { onsite occupancy factor (1.0 for the analyses herein) (WHC-SD-WM-SARR-016 } \\
& \text { [Van Keuren 1996a]), } \\
& \mathrm{ULD}_{\text {inh }}=\text { inhalation unit liter dose }(\mathrm{Sv} / \mathrm{L}) \text {, } \\
& \mathrm{ULD}_{\text {ing }}=\text { ingestion }\left(\mathrm{Sv}-\mathrm{m}^{3} / \mathrm{s}-\mathrm{L}\right) \text {. }
\end{aligned}
$$

The source term, $\mathrm{Q}$, is the amount of radioactive material released to the environment. The initial source term is the amount of radioactive material driven airborne at the accident source. The initial respirable source term, a subset of the initial source term, is the amount of radioactive material driven airborne at the accident source that can be inhaled. Lesser source terms are determined by applying filtration or deposition factors to the initial source term.

For the analyses herein, the methodology accounts for the fact that different atmospheric conditions are conservative for the two release mechanisms, wind-driven release from the Supplemental Cover and wind-driven wet entrainment from the waste pool. The equations below are used to incorporate these two effects.

$$
\mathrm{D}_{\mathrm{inh}}=\left[(\mathrm{Q} \times \chi / \mathrm{Q})_{\mathrm{sc}}+(\mathrm{Q} \times \chi / \mathrm{Q})_{\mathrm{wr}}\right] \times \mathrm{R} \times \mathrm{ULD}_{\mathrm{inh}}
$$




$$
D_{\text {ing }}=\left[(Q \times \chi / Q)_{s c}+(Q \times \chi / Q)_{\mathrm{wr}}\right] \times U_{L} D_{\text {inh }}(\text { Eq. 4) }
$$

where:

subscript sc denotes the $\mathrm{Q}$ and $\chi / \mathrm{Q}$ product for release from the Supplemental Cover subscript wr denotes the $\mathrm{Q}$ and $\chi / \mathrm{Q}$ product for release due to wet-entrainment from the pool.

In the cases for leaks within a pit and no surface pool, equations one and two above apply and the $\chi / Q$ values are for low wind speeds (i.e. the same as used for $[\chi / Q]_{s c}$ ). equation:

The airborne source term is typically estimated by the following five-component linear

$$
\mathrm{Q}=\mathrm{MAR} \times \mathrm{DR} \times \mathrm{ARF} \times \mathrm{RF} \times \mathrm{LPF} \text { (Eq. 5) }
$$

where:

$$
\begin{aligned}
\mathrm{Q} & =\text { Airborne Source Term } \\
\mathrm{MAR} & =\text { Material-at-Risk } \\
\mathrm{DR} & =\text { Damage Ratio, } \\
\mathrm{ARF} & =\text { Airborne Release Fraction } \\
\mathrm{RF} & =\text { Respirable Fraction }, \text { and } \\
\mathrm{LPF} & =\text { Leak Path Factor. }
\end{aligned}
$$

The initial source term and initial respirable source term are products of the first three factors and first four factors, respectively. A depleted source term after a subsequent stage of deposition or filtration is a product of the initial source term multiplied by the leak path factor of the specific stage.

\subsection{MATERIAL-AT-RISK (MAR)}

The material-at-risk is the amount of radionuclides available to be acted on by a given physical stress. For tank farm facilities, the MAR is taken to be the maximum quantity of radionuclide present or reasonably anticipated in each location. In the analyses herein for leaks inside $\mathrm{COBs}$, there are two materials-at-risk. These are the quantity of waste leaked onto the soil and the quantity of waste released from the Supplemental Cover.

\subsection{DAMAGE RATIO (DR)}

The damage ratio is the fraction of the MAR actually impacted by the accident-generated conditions. The DR is estimated based upon engineering analysis of the response of structural materials and materials-of-construction for containment to the type and level of stress/force 
generated by the event. Standard engineering approximations are typically used. These approximations often include a degree of conservatism due to simplification of phenomena to obtain a useable model, but the purpose of the approximation is to obtain, to the degree possible, a realistic understanding of potential effects. For the analyses herein, the DR is unity.

\subsection{AIRBORNE RELEASE FRACTION (ARF)}

The ARF is the coefficient used to estimate the amount of a radioactive material suspended in air as an aerosol and available for transport due to a physical stress from a specific accident. For discrete events, the ARF is a fraction of the material affected.

The ARFs used in the following analyses are taken from DOE (1994) which are based primarily upon experimentally measured values for the specific material (e.g., plutonium, uranium, mixed fission products) or surrogates subjected to the particular type of stress under controlled conditions. Attention is given to the parameters, if known, that may have a significant influence upon suspension by the specific mechanism and the uncertainty in the measurement as indicated by the variability of the results.

It is important to note that the experiments discussed in DOE (1994) evaluate release phenomena holistically. No attempt is made to precisely characterize total airborne material in terms of individual mechanisms acting within an overall given release.

\subsection{RESPIRABLE FRACTION (RF)}

The RF is the fraction of airborne radionuclides as particles that can be transported through air and inhaled into the human respiratory system and is commonly assumed to include particles 10- $\mu \mathrm{m}$ Aerodynamic Equivalent Diameter (AED) and less. The principal emphasis in this document is directed toward the potential downwind hazard to the populations at some distance from the point of source term generation. The product of the ARF and RF are frequently presented as RRF, the respirable release fraction. For the analyses herein, the RRF values will be used.

\subsection{LEAK PATH FACTOR (LPF)}

The LPF is the fraction of the radionuclides in the aerosol transported through some confinement deposition or filtration mechanism. The LPF is a calculated or standard value based upon (1) established relationships between size of the particulate material, airborne transport mechanisms, and losses by depositions mechanisms, or (2) specified filtration efficiencies. For the analyses herein, the LPF is unity for waste leaked to form a pool on the soil. The derivation for an LPF for aerosols generated by splash, splatter, and spray inside the Supplemental Cover is described in sections 4.3.1 and 4.3.2. Based on the sections above, the source term, $Q$, for the analyses herein becomes the following: 
TWR-3738, Rev. 1

$$
Q=\text { MAR } \times \text { RRF } \times \text { LPF }
$$

\subsection{TOXICOLOGICAL ANALYSIS}

The methodology that is used to calculate the toxicological exposure consequences is documented in WHC-SD-WM-SARR-011 (Van Keuren 1996b). In this method, the released quantity (or release rate) is multiplied by the appropriate sum-of-fraction multiplier, $\mathbf{M}_{\text {sof, from }}$ Table 3-8 of WHC-SD-WM-SARR-011 (Van Keuren 1996b). Msof values are dependent on the type of release (puff-type or continuous), the waste material released, and the event frequency. The following equation is used for the analyses herein:

$$
\mathrm{SOF}=\mathrm{Q}^{\prime} \times \mathrm{M}_{\mathrm{SOF}} \quad \text { (Eq. 7) }
$$

where:

SOF $=$ denotes the sum of toxicological exposure fractions for each toxic chemical as compared to its exposure criteria,

$\mathrm{Q}^{\prime}=$ quantity released in units of $\mathrm{L} / \mathrm{s}$,

$\mathrm{M}_{\text {SOF }}=$ sum-of-fraction multiplier in units of $\mathrm{L}^{-1}$ or $\mathrm{s} / \mathrm{L}$. equation:

Toxicological consequences can also be estimated using an airborne release rate using the

$$
\mathrm{SOF}=\mathrm{Q}^{*} \mathrm{ARR} * \mathrm{M}_{\mathrm{SOF}}
$$

where:

$$
\mathrm{Q}=\text { respirable source term }(\mathrm{L})
$$

$A R R=$ airborne release rate $(1 / s)$

$\mathrm{M}_{\text {SOF }}=$ sum-of-fraction multiplier (s/L)

\subsection{EXPOSURE DURATIONS}

For unmitigated events, onsite individuals are assumed to be exposed to accidental releases for 12 hours. The basis for this is that a crew may be required to work an extended shift which may be as long as 12 hours. Offsite individuals are assumed to be exposed to accidental releases for 24 hours. Offsite consequences consider ingestion for 24 hours after the release as well as inhalation. Mitigated exposure durations depend upon the timing of the control used (e.g., accident detection, evacuation). For the mitigated accidents analyzed herein, the onsite individual is assumed to be exposed for one hour. This is conservatively based on the time required to acknowledge the leak alarm $(30 \mathrm{~min}$.) plus the time required to evacuate the affected area. 


\subsection{RISK EVALUATION GUIDELINES}

For "Anticipated" events, the risk guidelines are $5 \mathrm{mSv}$ onsite and $1 \mathrm{mSv}$ offsite. Toxic chemical risk guidelines require the SOF consequences to be less than 1 .

\subsection{ATMOSPHERIC DISPERSION}

The Gaussian straight-line continuous plume model is employed for calculating atmospheric diffusion. The method assumes a ground level release and the concentration is calculated at the lateral centerline of the plume. Normally for safety analysis purposes, the $\chi / Q$ is chosen to represent "near" worst case conditions of wind speed, direction, atmospheric stability, and receptor location. "Near" worst case is usually defined as the combination which is bounding $95 \%$ of the time for all sectors or $99.5 \%$ of the time in any given sector. Since the $\chi / Q^{\prime}$ is inversely proportional to wind speed, a low wind speed condition is worse.

Specific values are used to calculate the dose component for release from the Supplemental Cover represented as $(\mathrm{Q} \times \chi / \mathrm{Q})_{\mathrm{sc}}$ in Equation 3. The $\chi / \mathrm{Q}_{\mathrm{sc}}$ values assume $1.1 \mathrm{~m} / \mathrm{s}$ wind speed and Class F conditions taken from Van Keuren (1996a) and shown in Table 3-1.

For an extended release duration (e.g., 24-hour release), Van Keuren (1996a) recommends use of a logarithmic interpolation between the plume meander $\chi / Q$ and the chronic annual average $\chi / Q$ for the onsite and offsite radiological calculations. For a desired time $t$, the logarithmic interpolation method for $\chi / Q(t)$ for the offsite receptor is given by:

$$
\chi / Q_{\text {off }}=10^{y} \quad(\text { Eqn. 9A })
$$

where $y=y(t)=a-[b / c] x[\log (2)-\log (t)]$ and

$\mathrm{a}=\log (2.12 \mathrm{E}-05)$

$\mathrm{b}=\log (2.12 \mathrm{E}-05)-\log (1.24 \mathrm{E}-07)$

$c=\log (2 \mathrm{hr})-\log (8760 \mathrm{hr})$

$\mathrm{t}=$ extended release time (hours).

The logarithmic interpolation for $\chi / Q(t)$ for the onsite receptor is given by:

$$
\chi / Q_{\text {on }}=10^{y} \quad(\text { Eqn. 9B })
$$

where $\mathrm{y}$ and $\mathrm{c}$ are the same as above, but

$$
\begin{aligned}
& a=\log (1.13 \mathrm{E}-02) \\
& \mathrm{b}=\log (1.13 \mathrm{E}-02)-\log (4.03 \mathrm{E}-4)
\end{aligned}
$$

The table below provides atmospheric dispersion coefficients for various durations. 
Table 3-1. Atmospheric Dispersion Coefficients $(\chi / \mathrm{Q})$.

\begin{tabular}{|c|c|}
\hline Receptor (duration) & Integrated $\chi / Q^{\prime}\left(\mathrm{s}^{\prime} \mathrm{m}^{3}\right)$ \\
\hline Onsite $(1 \mathrm{hr})$ & $3.41 \mathrm{E}-02$ \\
\hline Onsite $(2 \mathrm{hr})^{\mathrm{a}}$ & $1.13 \mathrm{E}-02$ \\
\hline Onsite $(12 \mathrm{hr})$ & $5.54 \mathrm{E}-03$ \\
\hline Onsite $(8760 \mathrm{hr}$, chronic annual) & $4.03 \mathrm{E}-04$ \\
\hline Offsite $(1 \mathrm{hr})$ & $2.83 \mathrm{E}-05$ \\
\hline Offsite $(2 \mathrm{hr})^{\mathrm{a}}$ & $2.12 \mathrm{E}-05$ \\
\hline Offsite $(4 \mathrm{hr})$ & $1.39 \mathrm{E}-06$ \\
\hline Offsite $(12 \mathrm{hr})$ & $7.07 \mathrm{E}-06$ \\
\hline Offsite $(24 \mathrm{hr})$ & $4.62 \mathrm{E}-06$ \\
\hline Offsite (8760 hr, chronic annual) & $1.24 \mathrm{E}-07$ \\
\hline
\end{tabular}

${ }^{a}$ Value used to interpolate for other dispersion coefficients.

Specific values are used to calculate the dose component for release from the pool by air entrainment (wet entrainment) which is represented as $(\mathrm{Q} \times \chi / \mathrm{Q})_{\mathrm{wr}}$ in Equation 3. For the mass release rates for wet (and dry) entrainment a high wind speed condition is worse. Thus, choosing a low wind speed $\chi / Q$ and a high wind speed MRR would provide an unrealistic estimate of potential consequences. The "near" worst case condition is taken to be the combination of atmospheric diffusion coefficient and mass release rate such that airborne concentrations downwind are bounding $95 \%$ of the time when the wind is in that direction. The method for obtaining $\chi / \mathrm{Q}$ sor wet entrainment is described in Refined Consequence Analysis of Subsurface Leak from TWRS Facilities that Result in a Surface Pool, TWR-3958 (Hey 1999a).

The combination of conditions most closely representing the $95 \%$ bounding (or greater) case is given in Table 3-2 below. These values represent point source acute releases at ground level. The $\chi / \mathrm{Q}_{\mathrm{wr}}$ values assume $9.8 \mathrm{~m} / \mathrm{s}$ wind speed and Class $\mathrm{D}$ conditions. For simplicity no credit is taken for plume meander or the distributed area of the source. The $\chi / \mathrm{Q}_{\mathrm{wr}}$ values are used in Equation 3 to calculate the dose component for release from wet entrainment from the pool represented as $(\mathrm{Q} \times \chi / \mathrm{Q})_{\mathrm{wr}}$.

Table 3-2. 95\% Atmospheric Diffusion Coefficients for Use in Conservative Estimates of Acute Exposure Due to Wind Entrainment (from Hey 1999)

\begin{tabular}{|l|c|c|}
\hline \multicolumn{1}{|c|}{ Receptor Description } & $\chi / \mathrm{Q}^{\prime}\left(\mathrm{s} / \mathrm{m}^{3}\right)$ & $\begin{array}{c}\text { Stability Class and Wind } \\
\text { Speed }\end{array}$ \\
\hline On-Site (100 m any direction) & $7.57 \mathrm{E}-4$ & D @ $9.8 \mathrm{~m} / \mathrm{s}$ \\
\hline Off-Site $(8,760 \mathrm{~m}$ north to near river bank) & $4.92 \mathrm{E}-7$ & D @ $9.8 \mathrm{~m} / \mathrm{s}$ \\
\hline
\end{tabular}




\subsection{UNIT LITER DOSES AND ACTIVITIES}

The RPP transfer pumps can potentially pump any waste within the RPP with a maximum solid content of 33 percent (liquid content $67 \%$ ). The analyses herein assume two values of solids concentrations, 33\% and 5\%, for the three types of waste, AWF, DST, and SST. The ULD values are taken from Van Keuren (1996a). Each of the waste types contain several radionuclides that contribute to the ULDs. The Cs-137 concentration provides an effective indicator of the relative gamma emissions for the purpose of shine and skyshine analysis.

$$
\mathrm{Gamma}=\mathrm{V} / \mathrm{V}_{\text {ref }} \times \mathrm{Cs} / \mathrm{Cs}_{\text {ref }} \times 65.9 \mathrm{mr} / \mathrm{hr} \times \mathrm{C} \quad(\text { Eqn. 10) }
$$

where:

C conversion from $\mathrm{mr}$ (milli-rem) to $\mathrm{Sv}$ (Sievert)

$\mathrm{V} \quad$ volume of pool (gal)

$\mathrm{V}_{\text {ref }} \quad$ volume of reference pool (1200 gal)

Cs Cs-137 activity in specified waste $(\mathrm{Bq} / \mathrm{L})$

$\mathrm{Cs}_{\text {ref }} \mathrm{Cs}-137$ activity in reference waste $(\mathrm{Bq} / \mathrm{L})$ table below.

The ULDs and Cs-137 concentrations for the six wastes analyzed herein are shown in the

Table 3-3. TWRS Waste Composite Unit Liter Doses and Activity Concentrations (from Hey 1999a)

\begin{tabular}{|l|l|l|l|}
\hline $\begin{array}{l}\text { Waste Composition } \\
\text { (percent liquids/solids) }\end{array}$ & $\begin{array}{l}\text { Inhalation } \\
\text { ULD }(\mathrm{Sv} / \mathrm{L})\end{array}$ & $\begin{array}{l}\text { 24hr Ingestion } \\
\text { ULD }\left(\mathrm{Sv}-\mathrm{m}^{3} / \mathrm{s}-\mathrm{L}\right)\end{array}$ & $\begin{array}{l}\text { Cs-137 Concentration } \\
(\mathrm{Bq} / \mathrm{L})\end{array}$ \\
\hline AWF 67/33 & $5.6 \mathrm{E}+5$ & $2.7 \mathrm{E}+0$ & $9.13 \mathrm{E}+10$ \\
\hline AWF 95/5 & $8.6 \mathrm{E}+4$ & $4.9 \mathrm{E}-1$ & $8.85 \mathrm{E}+10$ \\
\hline DST 67/33 & $1.8 \mathrm{E}+5$ & $2.0 \mathrm{E}-1$ & $5.90 \mathrm{E}+10$ \\
\hline DST 95/5 & $3.2 \mathrm{E}+4$ & $8.9 \mathrm{E}-2$ & $5.90 \mathrm{E}+10$ \\
\hline SST 67/33 & $8.0 \mathrm{E}+4$ & $1.4 \mathrm{E}+0$ & $4.77 \mathrm{E}+10$ \\
\hline SST 95/5 & $2.1 \mathrm{E}+4$ & $2.5 \mathrm{E}-1$ & $2.59 \mathrm{E}+10$ \\
\hline
\end{tabular}

\subsection{SUM OF FRACTIONS MULTIPLIER}

The SOF multipliers depend upon the accident frequency selection. For most accidents the frequency is identified to be "Anticipated." The SOF multipliers for the wastes analyzed herein are calculated from data taken from Van Keuren (1996b) and shown below. 
Table 3-4. Anticipated-Frequency Continuous-Release SOF Multipliers (s/L)

\begin{tabular}{|c|c|c|}
\hline Waste Form & Onsite & Offsite \\
\hline AWF 67/33 & $1.26 \mathrm{E} 4$ & $6.83 \mathrm{E} 1$ \\
\hline AWF $95 / 5$ & $1.04 \mathrm{E} 4$ & $1.75 \mathrm{E} 1$ \\
\hline DST 67/33 & $1.26 \mathrm{E} 4$ & $6.83 \mathrm{E} 1$ \\
\hline DST $95 / 5$ & $1.04 \mathrm{E} 4$ & $1.75 \mathrm{E} 1$ \\
\hline SST 67/33 & $1.96 \mathrm{E} 4$ & $3.64 \mathrm{E} 1$ \\
\hline SST $95 / 5$ & $1.11 \mathrm{E} 4$ & $1.23 \mathrm{E} 1$ \\
\hline
\end{tabular}

\subsection{SOURCE TERM}

There are two sources of exposure in these analyses. One is the direct gamma-ray exposure to those in the vicinity of a surface pool in the cases of leaks resulting in surface pools. The other is the transport of aerosols downwind. Leaks which remain confined under shielded cover blocks will not produce a significant gamma-ray exposure. Leaks that overflow their confinement or remain confined but without significant shielding (e.g., clean out boxes) will expose nearby onsite personnel to gamma radiation. Transport of aerosols downwind causes exposure to onsite and offsite personnel.

\subsection{LEAK VOLUME}

One transfer control currently relied upon to mitigate the consequences of a leak is a transfer pump shutdown. However, after the pump is turned off the leak may continue because there is still the potential to drain back and/or siphon waste contained in piping at higher elevations than the leak location. The leak rate should never exceed the level achieved when the pump was running (i.e., $20 \mathrm{gpm}$ ), but for conservatism it is not assumed to be less. In these analyses of leaks in COBs, the drain leak is assumed to be identical to the pumped leak rate (20 $\mathrm{gpm})$.

The COB analysis assumes that the transfer lines are constructed of 3 in schedule 40 pipe which holds a liquid volume of $0.384 \mathrm{gal} / \mathrm{ft}$. The longest length of transfer pipe currently under consideration is $27,776 \mathrm{ft}(\mathrm{HNF} 1998 \mathrm{cb}$ ). This analysis conservatively assumes that $100 \%$ of the contents of an assumed length of 3 inch schedule 40 pipe drains back through the leak at a rate of $20 \mathrm{gpm}$. This analysis is conservative for transfer lines of smaller inside diameter.

The total leak volume for COB cases includes the amount leaked before leak detection and pump shutdown (i.e. $20 \mathrm{gpm}$ for 30 minutes) and the drain back volume. It is slightly conservative to assume that no waste remains confined (i.e. ignore the 50 gallon holdup in the $\mathrm{COB}$ ) and that all waste contributes to a surface pool. Consistent with this assumption is that there is no significant volume leaked prior to leak detection, or that leak detection is practically instantaneous. In the case of the $\mathrm{COB}$, it is assumed that the leak detector is 2 inches above the 
floor. This corresponds to a volume of about 5 gallons, so leak detection should occur in about 15 seconds ( $5 \mathrm{gal} / 20 \mathrm{gal} / \mathrm{min} \times 60 \mathrm{~s} / \mathrm{min})$.

For the cases of leaks inside pits, the confinement structure is large and there is a significant leak volume needed for leak detection. Additionally, a leak rate much lower than $20 \mathrm{gpm}$ is sufficient to saturate the pit volume with aerosol. Therefore, rapid leak detection is not assured. However, consequences are calculated conservatively by assuming that $100 \%$ of the pit volume is displaced to the environment within 1 hour. Therefore, as long as the leak remains confined, neither leak detection or onsite worker evacuation is credited. For additional analyses, the reader may also refer to the mitigated leak scenario analyzed in Hall (1996c) which was done for the 241-AP valve pit.

There are two leak quantities to consider. The first is for the onsite MEI. His/her exposure is limited to one hour. The second is for the offsite MEI whose exposure period is 24 hours. For simplicity, doses for the $1 \mathrm{hr}$ and $24 \mathrm{hr}$ exposures are conservatively calculated for the maximum pool dimensions obtained at 1 and 24 hours, respectively. For the leaks in a COB, the onsite MEI is exposed to the aerosols from the SC and the surface pool and the gamma from the pool during one hour. The offsite MEI is exposed to the 600 gal pumped out plus the drain back quantity within 24 hours. For the pit leak cases, both the onsite and offsite MEI exposure period is less than one hour.

\subsection{GAMMA-RAY EXPOSURE}

For the COB leak cases, a conservative gamma-ray exposure estimate is made assuming an idealistic case of a circular pool with an onsite receptor located $100 \mathrm{~m}$ from its center. This approach is typical of most TWRS FSAR supporting analyses (Hall 1996a, Hall 1996b, Van Vleet 1997) and meets the definition of onsite maximum exposed individual (MEI) in HNFPRO-517. Of course, the actual spill shape would depend upon local soil elevations and conditions.

The area of the source depends upon the amount of spreading assumed. Even in the ideal case of a perfectly flat area, this would be a function of waste viscosity, surface porosity and moisture content, ambient temperature, etc. A spreading factor of $8.7 \mathrm{ft}^{-1}$ has been used in a number of TWRS FSAR supporting analyses (Hall 1996a, Van Vleet 1997). This spreading factor was calculated by dividing the surface area of contaminated soil by the estimated spill volume of an actual event. The event occurred at Hanford S farm in 1973 where an estimated 8,600 gal of liquid waste spilled onto $10,000 \mathrm{ft}^{2}$ of soil surface (ARH-2977 RD 1974). The depth of soil contamination varied between 2 in and 18 in.

It is typically assumed that there is no immediate infiltration into the soil due to the possibility of ice or salt formation when a saturated waste solution comes into contact with a colder environment. The presence of blacktop or concrete surfaces could also promote formation of a surface pool. This is a conservative assumption because assuming the waste infiltrates the soil reduces the gamma-ray shine by approximately a factor of 4 (assuming a void fraction of 
0.4). Due to the fact that the exact location of the leak can not be predicted, nor can the ambient or surface condition be known, no credit for infiltration is taken.

\subsection{EXPOSURE DUE TO INHALATION OF RESPIRABLE AEROSOLS}

Respirable sized liquid aerosols can be created any time liquid drops are exposed to shear forces. The types of releases that have typically been considered for waste transfers have been categorized as a spray, splash and splatter, or entrainment due to wind. The latter case is actually based on measurements from ponds experiencing wave action which is another form of splash and splatter. The dominant mechanism by far is a spray. All such analyses of unmitigated spray releases of Hanford tank waste directly into the environment yield unacceptable results. These analyses are very conservative. They usually assume maximum pressures, a viscosity equal to that of water, optimum crack widths, and take no credit for plugging due to suspended solids. Nevertheless, it is difficult to prove these optimal conditions can not exist. Hence it has already been concluded that a spray release directly into the atmosphere must always be prevented or mitigated by a confinement barrier. See Section 2.0 .

\subsubsection{Aerosol Generation Due to Splashing and Splattering}

TWRS AB supporting analyses have also made use of a splash/splatter source term to represent liquid waste falling onto a surface out in the open. Hall (1996a) makes use of a respirable release fraction (RRF) of 4E-5 taken from Section 3.2.3.2 of DOE (1994) which is the recommended value for slurries based on a 1 liter sample dropped from a height of $3 \mathrm{~m}$. Jones (1998) used a RRF of 5E-7 taken from the same reference but for a 1 L UNH solution dropped from a height of $1 \mathrm{~m}$. Himes (1997) uses an Archimedes relationship to calculate the respirable aerosol from a falling vertical jet of liquid from height $\mathrm{H}$. Although the application of these values yield small aerosol quantities in comparison to an open spray, it can become a dominant factor when the spray release is mitigated.

DOE (1994) referenced measurements are based on one liter or smaller samples and the trend is a decrease in the release fraction for an increase in sample size. It is very conservative to use these values when applying them to large volume releases such as the several thousand gallon releases typically considered in waste transfer consequence analysis.

When mitigation is provided such that these splash and splatter releases occur within a confinement, it is more accurate to base the release on the aerosol escaping the confinement as opposed to the aerosol generation rate. In the event that a confinement overflows, its physical orientation must not allow waste material to spill freely from a height and splatter against the waste below. In Hanford waste transfers, the various pits with cover blocks and boxes with supplemental covers as described in HNF-2329 (HNF 1997) meet this criterion.

Waste overflowing a pit or box and running down a short vertical wall section should not cause the aerosol fractions observed in Mishima's referenced liquid drop studies. Instead, it is proposed that the multitude of aerosol generating mechanisms which occur within such a 
TWR-3738, Rev. 1

confinement be represented by a value more representative of the quantity escaping the confinement. This is the approach taken in Hall (1996c) which provides a bounding analysis for very large confinement structures.

\subsubsection{Aerosol Release from Confinement}

An aerosol generator inside a confined space does not have to be efficient in order to saturate the confined volume with aerosols. Such an aerosol generator could result from the splash and splatter of a low velocity stream of waste impacting a wall or piece of equipment. Both the aerosol concentration and particle size distribution are highly transient values.

When the aerosol is generated inside a confined volume, the source term is better defined by the release rate of aerosols from the confinement, rather than the generation rate within the confinement. This is because there are a number of depletion mechanisms occurring which remove aerosols from the air. The more important mechanisms are gravitational settling, coagulation, condensation, and inertial impaction.

The approach taken in many TWRS AB supporting analyses is to base the source term on the volume of air displaced or vented from the confinement and assume that the escaping air contains a quasi-equilibrium respirable aerosol concentration of $100 \mathrm{mg} / \mathrm{m}^{3}$ (Hall 1996a, Jones 1998, Hall 1996b, Van Keuren 1998). The displaced volumes have typically been calculated to be $35-40 \%$ of the total due to thermodynamic effects plus the volume of leakage collected in the confinement. This latter volume is based on either the product of leak rate and leak duration, or half of the confinement volume (assuming the source of aerosol generation is covered at that point). Additionally, venting due to natural breathing effects (i.e., wind) is a consideration. Typically, $100 \%$ of the confinement volume is assumed to be displaced as a conservative representation of all of these effects. This creates perhaps a counter intuitive result that the larger the confinement, the larger the dose consequence. Larger confinement volumes do not necessarily result in larger doses because one would expect an increased opportunity for aerosol depletion. However, for simplicity this characteristic is ignored.

\subsubsection{Aerosol Release from Supplemental Cover}

Figure 1 shows a standard supplemental COB enclosure. The volume of this structure is $1.2 \mathrm{~m}^{3}$. Surface wind would tend to sweep out aerosols suspended within the enclosure. The higher the wind speed, the higher the release. However, the atmospheric diffusion coefficient is inversely proportional to wind speed and effectively compensates the increase in release rate such that downwind aerosol concentration remains unchanged. The side walls of the enclosure are approximately one inch off the ground. A volumetric exchange rate of $5.9 \mathrm{vol} / \mathrm{hr}$ is calculated in Appendix A for this enclosure under low wind speed conditions. For conservatism this analysis assumes a volumetric release rate of $6 \mathrm{vol} / \mathrm{hr}$ of aerosol laden air. The escaping air is assumed to have an aerosol concentration of $100 \mathrm{mg} / \mathrm{m}^{3}$. The duration of this release is expected to last until $100 \%$ of the transfer line has drained back through the leak at a rate of 20 gpm. To ensure a conservative estimate of the release, the total release duration, $T_{t}$, is calculated with the following equation: 


$$
\mathrm{T}_{\mathrm{t}}(\min )=\mathrm{T}_{\mathrm{a}}+\mathrm{T}_{\mathrm{s}}+\mathrm{V}_{\mathrm{d}} / 20+\mathrm{T}_{\mathrm{sc}} \quad \text { (Eqn. 11) }
$$

where:

$$
\begin{aligned}
& \mathrm{T}_{\mathrm{a}}=\text { time for leak detection and alarm }(0 \mathrm{sec}) \\
& \mathrm{T}_{\mathrm{s}}=\text { time required for pump shut down }(30 \mathrm{~min}) \\
& \mathrm{V}_{\mathrm{d}}=\text { volume of waste in assumed length of pipe }(\mathrm{gal}) \\
& \mathrm{T}_{\mathrm{sc}}=\text { time for Supplemental Cover to release one volume of aerosol }(10 \mathrm{~min}) \text {, and } \\
& \mathrm{T}_{\mathrm{t}}=\text { is limited to } 1440 \mathrm{~min}(24 \text { hours })
\end{aligned}
$$

\subsubsection{Aerosol Release from Pits}

The waste transfer structures identified to have a volume less than $15 \mathrm{~m}^{3}$ but not fitted with supplemental covers have been described as typical concrete valve pits with interlocking concrete cover blocks and shield plugs held in place by gravity. The externals walls of the pits have also been described as straight walled and not exceeding a height of more than a couple of feet. This description of the confinement structure meets the three-part criteria listed in Section 2.0, Means of Mitigation. Therefore no supplemental cover is required because the valve pit with cover blocks and shield plugs in place already provides the necessary confinement function in order for consequences to remain bounded by the results reported in here.

As long as the cover blocks and shield plugs are free to float upwards, the internal pressure within the valve pit cannot exceed $2-3$ psig because this is the pressure due to the weight of the cover block (e.g., 2 feet high $\times 140 \mathrm{lb} . / 144 \mathrm{in}^{2}=2 \mathrm{lb} / \mathrm{in}^{2}$ ). The efficiency of a liquid jet at that pressure to generate aerosol is very low and negligible in comparison to the wet entrainment rates assumed in the analysis. Even if the cover blocks were mechanically restrained, a 3 inchgap $1 / 4$ inch wide could easily accommodate a $20 \mathrm{gpm}$ flow rate at 3 psi. Since no special means are available to seal the cover blocks against any significant pressure differential (i.e., $>3$ psi), the cracks around the perimeter of the cover blocks are more than sufficient to accommodate the leak without resulting in a high pressure spray.

The exterior walls of a concrete valve pit are typically perpendicular to the ground, do not have a lip or flange, and are usually one to two feet above grade. Should the pit overflow, the waste would exit the cracks in the perimeter of the cover blocks or shield plug, run across to the edge of the valve pit, and down its side onto the ground. This scenario is very much different from the configuration discussed in Section 3.2.3.2 of Mishima's liquid drop studies. These studies involved the dropping of liter quantities of UNH and other solutions onto a hard surface from one or more meters in height. The intent of these studies was to quantify the source term of the subsequent splattering of the liquid onto the floor. This characterization of what would happen in the event a valve pit overflowed is unnecessarily conservative when the geometry of the pit does not create the situation where a free fall could occur. As long as this is the case, then the aerosol releases considered here conservatively represent the consequences of a leak within a small volume structure. 
The tops of pits are slightly above grade but the cover blocks are seated within the walls. Thus, surface wind would not impinge directly on joints or spaces. A leak inside a pit could generate aerosols which could then be released by the combined effects of displacement by leaking waste and heating of pit air. Similar to the approach with COB leaks, a simple approach to aerosol release is used. The air escaping the pit is assumed to contain a quasi-equilibrium concentration of aerosol $\left(0.1 \mathrm{gram} / \mathrm{m}^{3}\right)$. It is further assumed that the entire volume of pit air is released within 1 hour irrespective of the pit volume or leak rate. For example, a $10 \mathrm{~m}^{3}$ pit would release 1 gram within 1 hour. Thus both the onsite and offsite MEI's are exposed to the entire release quantity within a short amount of time.

\section{Figure 1. Standard Supplemental COB Enclosure}
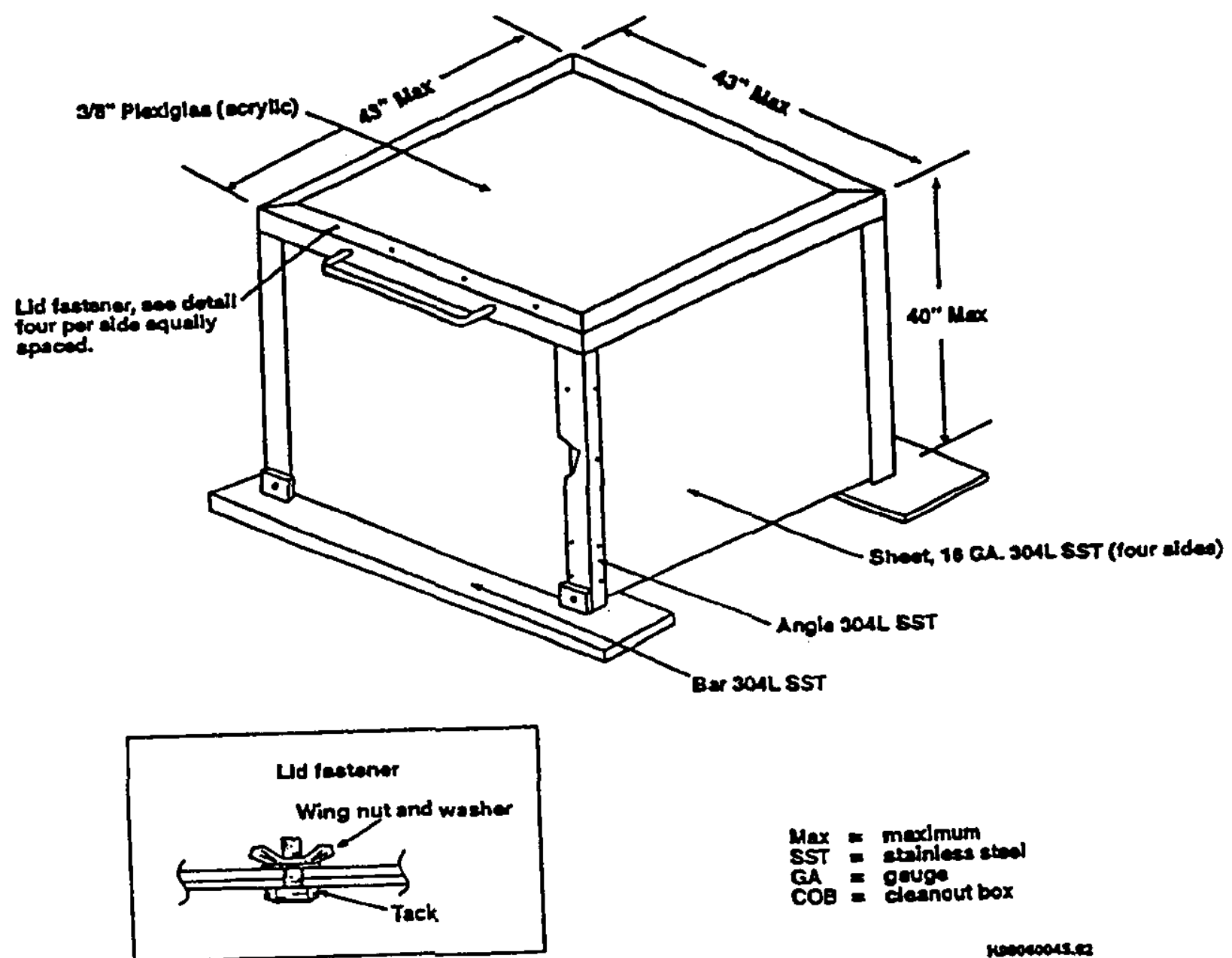

romeceses 


\subsubsection{Aerosol Entrainment from Waste Material Exposed to Wind}

Because of their small volumes, leaks within COBs are assumed to lead to surface pools. Aerosols generated from wind induced entrainment have also been considered in TWRS AB supporting analyses (Hall 1996a, Jones 1998, Hall 1996b, Van Vleet 1997). The consensus of these analyses is that entrainment would be worse once the spill had dried. But for the one hour onsite MEI exposure period considered in the mitigated analysis, it is safe to assume that wet conditions characterize the spill. What is more difficult to assign is the entrainment rate appropriate for such conditions. The value used in the above referenced analyses is $2 \mathrm{E}-10$ $\mathrm{kg} / \mathrm{m}^{2}-\mathrm{s}$. This value was intended to be conservative for the low wind speed $\chi / Q$ applied in the dose estimate. It is conservative in that it actually represents wave action occurring in ponds of water with a wind speed of $5 \mathrm{~m} / \mathrm{s}$ and a fetch of $200 \mathrm{~m}$.

Aerosol generated from wind induced entrainment is evaluated more rigorously herein using the method previously reported in Refined Consequence Analysis of Subsurface Leaks from TWRS Facilities that Result in a Surface Pool, TWR-3958, Rev. 1 (Hey 1999). Estimated mass release rates (MRR) from large outdoor ponds are provided in Figure 3-8 of Mishima (1994) as a function of wind speed and wind blown distance across the pond (i.e., fetch). A least squares fit to the data yielded the following equation

$$
M R R=2.14 \times 10^{-15} F u^{3.762} \quad(\text { Eqn. 12) }
$$

where:

MRR mass release rate in $\mathrm{kg} / \mathrm{m}^{2}-\mathrm{s}$
$\mathrm{u}$ wind speed in $\mathrm{m} / \mathrm{s}$,
$\mathrm{F}$ fetch in meters.

The maximum deviation between Equation 12 and the data in Figure 3-8 of Mishima (1994) is $\pm 12 \%$ (Hey1999).

In the COB analyses herein, the fetch is taken to be the pool diameter, D. Note that Equation 12 predicts that the MRR is proportional to wind speed raised to the power of 3.762. Thus, high wind speed conditions are predicted to yield much higher mass release rates, a conclusion that agrees with intuition. However, a higher wind speed also results in greater dispersion and would tend to lower downwind aerosol concentrations. Hence, an optimum wind speed exists such that downwind concentrations are at their worst. In order to select a wind speed which is both relatively frequent and representative of an optimal range of entrainment and dispersion conditions, a 95 percentile was chosen of the combined function of MRR * $\chi / Q$. Utilizing the Hanford 200 Area joint frequency (i.e., meteorological) data, analysis showed this condition to be represented by a wind speed of $9.8 \mathrm{~m} / \mathrm{s}$ and Pasquill stability class $D$. In other words, for wind/surface entrainment conditions, a wind speed of $9.8 \mathrm{~m} / \mathrm{s}$ and Pasquill D stability class yields a downwind aerosol concentration which is bounding 95 percent of the time. This approach provides approximately the same degree of conservatism as the 99.5 percent sector $\chi / Q$ 
typically used in accident analyses for releases independent of wind speed. For further information on this approach, the reader should refer to Hey (1999). as follows:

Using a wind speed of $9.8 \mathrm{~m} / \mathrm{s}$, Equation 12 is evaluated for a pool diameter D in meters

$$
\begin{aligned}
\text { MRR } & =2.14 \mathrm{E}-15 \times \mathrm{D} \times 5358 \\
& =1.147 \mathrm{E}-11 \times \mathrm{D} \mathrm{kg} / \mathrm{m}^{2}-\mathrm{s}
\end{aligned}
$$

The data presented in Mishima (1994) actually represents wave action occurring in ponds of water. This phenomenon is not expected to occur in a relatively small waste spill as compared to a pond. However, it does represent the best available data at this time and the MRR predicted from its use should be a conservative mathematical representation of the TWRS waste spill scenario. Wet entrainment is assumed to occur for the duration of the pipe leak.

After the leak is stopped the pond could be assumed to become static and, without mitigation measures, dry out. TWRS AB analyses have also considered dry entrainment (Jones 1998, Hall 1996b, Van Vleet 1997). All three analyses use a RRF=8.4E-5 from DOE Section 3.2.4.4 (1994) which is applied to the entire spill quantity. Jones (1998) does not include dry entrainment in offsite doses because emergency response procedures are credited with leakage containment and removal (see Section 2.0). The same control is assumed in this mitigated analysis and dry entrainment is not included in any onsite or offsite dose consequence.

\subsection{CONSEQUENCE ANALYSIS AND CONCLUSIONS}

\subsection{MAXIMUM TRANSFER PIPE LENGTHS FOR LEAKS IN CLEANOUT BOXES}

This analysis estimates the radiological and toxicological consequences for the six wastes listed in Section 1, namely AWF 67/33, AWF 95/5, DST 67/33, DST 95/5, SST 67/33, and SST $95 / 5$. The cases analyzed determine the longest length of transfer pipe for which the radiological and toxicological consequences will be equal to or less than the consequences reported in Jones (1998) or in the REGs.

\subsubsection{Maximum Pipe Lengths for Consequences Less than in Jones (1998)}

The radiological and toxicological dose calculation methodology described in Section 3 was used. The individual case calculations were performed with the aid of spreadsheets that are included in Appendix B. To find the longest pipe length for each of the six wastes, an iterative solution process was used. A trial pipe length was selected and inserted in the spreadsheet. In addition, a preliminary value for the total leak duration was selected. This value was typically 2 hours and determines the offsite $\chi / Q$ value from Equation 9 . The spreadsheet calculates the resulting consequences including a key parameter, the total leak time corresponding to the input 
pipe length as shown in Equation 11. A time value less than this total release time is inserted into Equation 9 and a new case is run with the resulting new value of offsite $\chi / Q$. After about 5 iterations, the consequences reach one of the limits from Jones 1998 (as shown in Table 5-1). At this point, the total leak time is evaluated with respect to the input time for the $\chi / Q$ calculation. Convergence is obtained when the time value input to Equation 9 for offsite $\chi / Q$ is less than the resulting total leak time from Equation 11. For example, for the case of AWF 67/33 waste, the leak time was about 4.1 hours and the time value for $\chi / Q$ was 4.0 hours. In all cases, a maximum time of 12 hours was used for determining the offsite $\chi / Q$ value even when leak durations were much longer (up to the maximum of 24 hours). This helps ensure that the results are conservative.

The results for all wastes are summarized below. The table compares the consequences to Calculation Notes for Surface Leak Resulting in Pool, TWRS FSAR Accident Analysis, WHCSD-WM-CN-049, Rev. 0-B (Jones 1998).

Table 5-1. Maximum Pipe Lengths for $20 \mathrm{gpm}$ COB Leak with Consequences within Present Authorization Basis

\begin{tabular}{|c|c|c|c|c|c|c|}
\hline $\begin{array}{c}\text { Waste Type } \\
\text { Liquid/Solid }\end{array}$ & $\begin{array}{c}\text { Pipe } \\
\text { Length } \\
\text { m (feet) }\end{array}$ & $\begin{array}{c}\text { Spill } \\
\text { Volume } \\
\text { L (gal) }\end{array}$ & $\begin{array}{c}\text { Onsite } \\
\text { Dose } \\
\text { Sv }\end{array}$ & $\begin{array}{c}\text { Offsite } \\
\text { Dose } \\
\text { Sv }\end{array}$ & $\begin{array}{c}\text { Onsite } \\
\text { Toxicological }\end{array}$ & $\begin{array}{c}\text { Offsite } \\
\text { Toxicological }\end{array}$ \\
\hline $\begin{array}{c}\text { Reference } \\
\text { (Jones 1998) }\end{array}$ & $\begin{array}{c}610 \\
(2,000)\end{array}$ & $\begin{array}{c}5,300 \\
(1,400)\end{array}$ & $5.1 \mathrm{E}-3$ & $6.6 \mathrm{E}-6$ & $1.4 \mathrm{E}-1$ & $7.5 \mathrm{E}-4$ \\
\hline AWF 67/33 & $\begin{array}{c}3,400 \\
(11,000)\end{array}$ & $\begin{array}{c}19,000 \\
(4,900)\end{array}$ & $4.3 \mathrm{E}-3$ & $6.6 \mathrm{E}-6$ & $2.0 \mathrm{E}-3$ & $1.7 \mathrm{E}-5$ \\
\hline AWF 95/5 & $\begin{array}{c}23,000 \\
(75,000)\end{array}$ & $\begin{array}{c}110,000 \\
(29,000)\end{array}$ & $1.5 \mathrm{E}-3$ & $4.5 \mathrm{E}-6$ & $1.6 \mathrm{E}-3$ & $3.1 \mathrm{E}-5$ \\
\hline DST 67/33 & $\begin{array}{c}17,000 \\
(55,000)\end{array}$ & $\begin{array}{c}83,000 \\
(22,000)\end{array}$ & $1.7 \mathrm{E}-3$ & $6.6 \mathrm{E}-6$ & $2.0 \mathrm{E}-3$ & $8.2 \mathrm{E}-5$ \\
\hline DST 95/5 & $\begin{array}{c}23,000 \\
(75,000)\end{array}$ & $\begin{array}{c}110,000 \\
(29,000)\end{array}$ & $8.5 \mathrm{E}-4$ & $1.7 \mathrm{E}-6$ & $1.6 \mathrm{E}-3$ & $3.1 \mathrm{E}-5$ \\
\hline SST 67/33 & $\begin{array}{c}23,000 \\
(75,000)\end{array}$ & $\begin{array}{c}110,000 \\
(29,000)\end{array}$ & $1.0 \mathrm{E}-3$ & $4.3 \mathrm{E}-6$ & $3.1 \mathrm{E}-3$ & $6.4 \mathrm{E}-5$ \\
\hline SST 95/5 & $\begin{array}{c}23,000 \\
(75,000)\end{array}$ & $\begin{array}{c}110,000 \\
(29,000)\end{array}$ & $4.1 \mathrm{E}-4$ & $1.1 \mathrm{E}-6$ & $1.7 \mathrm{E}-3$ & $2.2 \mathrm{E}-5$ \\
\hline
\end{tabular}

From the table above it is seen that the limiting criterion is the offsite dose. The onsite dose is close to the limit for AWF 67/33 (4.3 versus 5.1) but far from the limit for SST 95/5 (4.1E-4 versus 5.1E-3). The toxicological consequences are far from the limits (about a factor of 9 or more). Four of the six wastes are within the criteria in Jones 1998 for connecting 3-inch schedule 40 pipe lengths of 75,000 feet (14.2 miles). This length is far greater than any in current designs. A 75,000 foot-length corresponds to a drainback volume of 28,800 gallons which is the maximum amount that can be leaked in 24 hours at a leak rate of $20 \mathrm{gpm}$ ( $20 \mathrm{gpm} \mathrm{x}$ 
$24 \mathrm{hr} \times 60 \mathrm{~min} / \mathrm{hr}$ ). Thus, longer pipe lengths do not increase the consequences at 24 hours for the offsite MEI.

The $20 \mathrm{gpm}$ leak of AWF 67/33 waste which has the highest Unit Liter Dose values is acceptable for pipe length up to about 11,000 feet. The limiting criterion for the AWF 67/33 waste is the dose to the offsite MEI, $6.6 \mathrm{E}-6 \mathrm{~Sv}$ in Jones 1998 . This length is likely to bound the longest transfer pipe length identified up to the present with the exception of the Replacement Cross-Site Transfer System (CSTS) which has a length of about 6.5 miles. For the 11,000 footlength to be limiting, the pipe would have to either slope along its entire length back to the leak site or be capable of inducing a siphon from the destination tank. This makes the possibility of such a case very improbable.

The 20 gpm leak of DST 67/33 waste (which has the next highest Unit Liter Dose values) is acceptable for pipe length up to about 55,000 feet. Its limiting criterion is also the dose to the offsite MEI, 6.6E-6 Sv. This length is likely to bound the longest transfer pipe length identified up to the present including the RCSTS. For the 55,000 foot-length to be limiting, the pipe would have to either slope along its entire length back to the leak site or be capable of inducing a siphon from the destination tank. This makes such a case very improbable.

It should be noted that the above results for leaks in clean-out boxes are not necessarily limited to cases where the transfer pump is shut off within 30 minutes. If the leak volume is limited to that represented by the pipe length which could drain back, then transfer pump shut off could occur later and still have consequences bounded by those reported above.

Some detailed results for the limiting case of AWF 67/33 waste are shown below in Table 5-2. The table lists the radiological and toxicological consequences by pathway. It is seen that the radiological consequences are due mostly to the release from the Supplemental Cover ("SupCover" in Table 5-2). The spreadsheets for all cases are included in Appendix B. 
TWR-3738, Rev. 1

Table 5-2. Details of Analysis for 20 gpm AWF 67/33 Leak in Cleanout Box

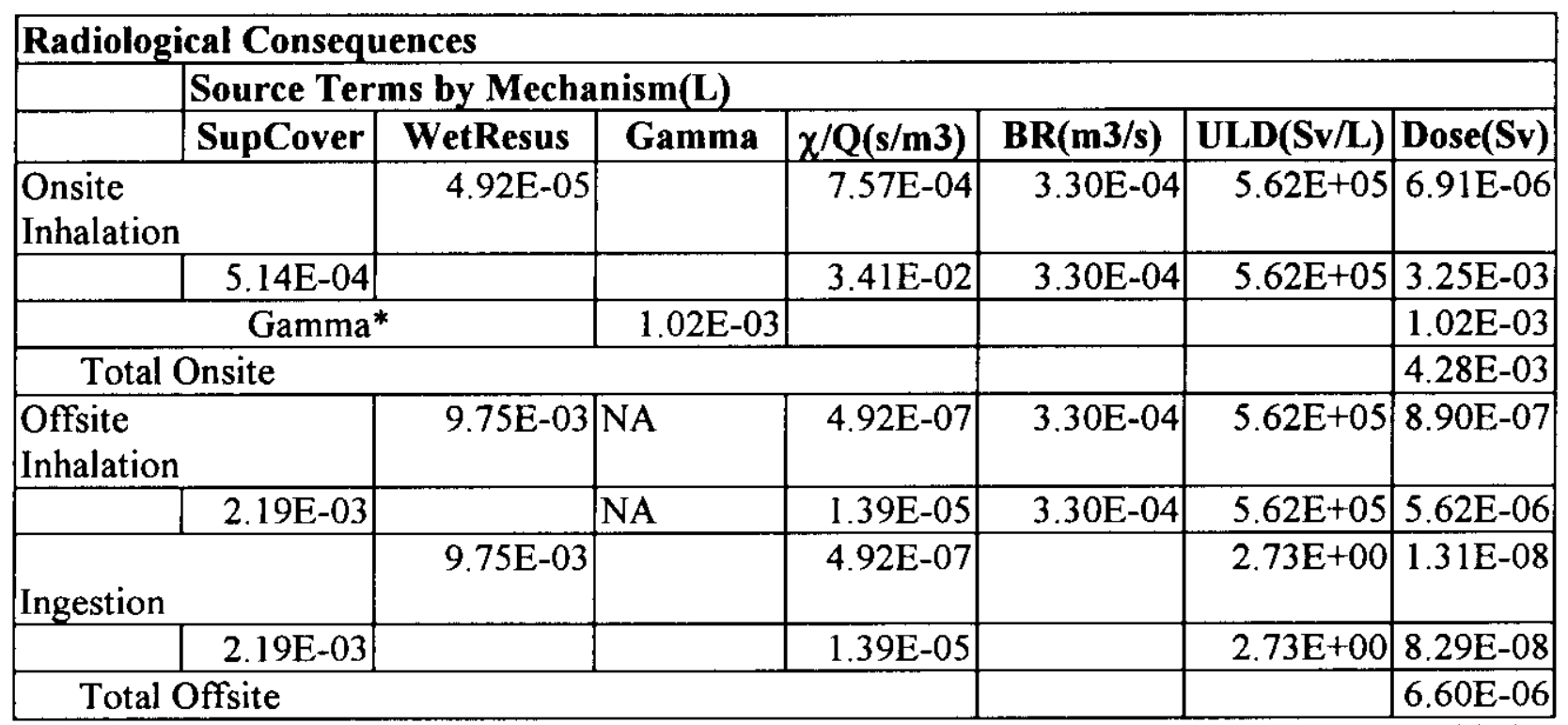

${ }^{*}$ Gamma $=$ (Shine+Skyshine for Reference Leak)x(Ratio of Lcak Volumes)x(Ratio of Cs137 Activities)

\begin{tabular}{|l|r|r|l|l|r|r|c|}
\hline \multicolumn{7}{|l|}{ Toxicological Consequences } & \\
\hline & Initial Rates (L/s) & 24 hour Rates (L/s) & \multicolumn{1}{l|}{} \\
\hline Location & SupCover & WetResus & SupCover & WetResus & Rate (L/s) & SOF Mult & \multicolumn{1}{c|}{ SOF } \\
\hline Onsite & $1.43 \mathrm{E}-07$ & $1.37 \mathrm{E}-08$ & & & $1.57 \mathrm{E}-07$ & $1.26 \mathrm{E}+04$ & $1.98 \mathrm{E}-03$ \\
\hline & & & & & & & \\
\hline Offsite & $1.43 \mathrm{E}-07$ & $1.37 \mathrm{E}-08$ & $1.43 \mathrm{E}-07$ & $1.13 \mathrm{E}-07$ & $2.56 \mathrm{E}-07$ & $6.83 \mathrm{E}+01$ & $1.75 \mathrm{E}-05$ \\
\hline
\end{tabular}

File:TWR3738Rev1/3738R1AWF67

\subsubsection{Maximum Pipe Lengths for Consequences Less than REGs}

Two additional cases for leaks into COBs were run to determine the longest transfer pipe length for which the consequences will be within the REGs. Only the cases for AWF 67/33 and DST $67 / 33$ needed to be run because these were the only cases restricted by Jones (1998) to a transfer pipe length less than 75,000 feet. The same analysis process using spreadsheets as described in section 5.1.1 was used. The results for all wastes are summarized below. 
TWR-3738, Rev. 1

Table 5-3. Maximum Pipe Lengths for $20 \mathrm{gpm}$ COB Leak Consequences within REGs

\begin{tabular}{|c|c|c|c|c|c|c|}
\hline $\begin{array}{c}\text { Waste Type } \\
\text { Liquid/Solid }\end{array}$ & $\begin{array}{c}\text { Pipe } \\
\text { Length } \\
\text { m (feet) }\end{array}$ & $\begin{array}{c}\text { Spill } \\
\text { Volume } \\
\text { L (gal) }\end{array}$ & $\begin{array}{c}\text { Onsite } \\
\text { Dose } \\
\text { Sv }\end{array}$ & $\begin{array}{c}\text { Offsite } \\
\text { Dose } \\
\text { Sv }\end{array}$ & $\begin{array}{c}\text { Onsite } \\
\text { Toxicological }\end{array}$ & $\begin{array}{c}\text { Offsite } \\
\text { Toxicological }\end{array}$ \\
\hline $\begin{array}{c}\text { SAR-067 } \\
\text { Table 4.3.1-1 }\end{array}$ & NA & NA & $5.0 \mathrm{E}-3$ & $1.0 \mathrm{E}-3$ & 1.0 & 1.0 \\
\hline AWF 67/33 & $\begin{array}{c}23,000 \\
(75,000)\end{array}$ & $\begin{array}{c}110,000 \\
(29,000)\end{array}$ & $4.3 \mathrm{E}-3$ & $2.9 \mathrm{E}-5$ & $2.0 \mathrm{E}-3$ & $1.2 \mathrm{E}-4$ \\
\hline AWF 95/5 & $\begin{array}{c}23,000 \\
(75,000)\end{array}$ & $\begin{array}{c}110,000 \\
(29,000)\end{array}$ & $1.5 \mathrm{E}-3$ & $4.5 \mathrm{E}-6$ & $1.6 \mathrm{E}-3$ & $3.1 \mathrm{E}-5$ \\
\hline DST 67/33 & $\begin{array}{c}23,000 \\
(75,000)\end{array}$ & $\begin{array}{c}110,000 \\
(29,000)\end{array}$ & $1.7 \mathrm{E}-3$ & $9.2 \mathrm{E}-6$ & $2.0 \mathrm{E}-3$ & $1.2 \mathrm{E}-4$ \\
\hline DST 95/5 & $\begin{array}{c}23,000 \\
(75,000)\end{array}$ & $\begin{array}{c}110,000 \\
(29,000)\end{array}$ & $8.5 \mathrm{E}-4$ & $1.7 \mathrm{E}-6$ & $1.6 \mathrm{E}-3$ & $3.1 \mathrm{E}-5$ \\
\hline SST 67/33 & $\begin{array}{c}23,000 \\
(75,000)\end{array}$ & $\begin{array}{c}110,000 \\
(29,000)\end{array}$ & $1.0 \mathrm{E}-3$ & $4.3 \mathrm{E}-6$ & $3.1 \mathrm{E}-3$ & $6.4 \mathrm{E}-5$ \\
\hline SST 95/5 & $\begin{array}{c}23,000 \\
(75,000)\end{array}$ & $\begin{array}{c}110,000 \\
(29,000)\end{array}$ & $4.1 \mathrm{E}-4$ & $1.1 \mathrm{E}-6$ & $1.7 \mathrm{E}-3$ & $2.2 \mathrm{E}-5$ \\
\hline
\end{tabular}

From the table above it is seen that all six waste types are within the REGs for the longest transfer pipe length of 75,000 feet ( 14.2 miles). This length is far greater than any in current designs. A 75,000 foot-length corresponds to a drainback volume of 28,800 gallons which is the maximum amount that can be leaked in 24 hours at a leak rate of $20 \mathrm{gpm}$ ( $20 \mathrm{gpm} \times 24 \mathrm{hr} \times 60$ $\mathrm{min} / \mathrm{hr}$ ). Thus, longer pipe lengths do not increase the consequences at 24 hours for the offsite MEI.

As in section 5.1.1, it should be noted that the above results for leaks in clean-out boxes are not necessarily limited to cases where the transfer pump is shut off within 30 minutes. If the leak volume is limited to that represented by the pipe length which could drain back, then transfer pump shut off could occur later and still have consequences bounded by those reported above.

\subsection{MAXIMUM VOLUMES FOR LEAKS IN PITS}

This analysis estimates the radiological and toxicological consequences for the six wastes listed in Section 1. The analyses were performed using as criteria the onsite and offsite radiological and toxicological doses for Anticipated Events in the REGs and the limits in Ryan (1999). The cases analyzed determine the largest pit volume for which the radiological and toxicological consequences will be equal to or less than the the REGs or, for the case of AWF waste, less than the consequences allowed by the Authorization Basis which is based on Ryan (1999). 
The radiological and toxicological dose calculation methodology described in Section 3 was used. The individual case calculations were performed with the aid of spreadsheets that are included in Appendix B. To find the maximum pit volume for each of the six wastes, a simple iterative solution process was used. A trial pit volume was selected and inserted in the spreadsheet. After about 3 iterations, the consequences reach one of the limits. The spreadsheets for all cases are provided in Appendix B.

\subsubsection{Maximum Pit Volumes for AWF Waste Leak Consequences Less than the AB}

The results for the two AWF cases run against the limits in Ryan (1999) are summarized in Table 5-4 below.

Table 5-4. Maximum Pit Volumes for AWF Waste Leak Consequences Less than the Authorization Basis

\begin{tabular}{|c|c|c|c|c|c|c|}
\hline $\begin{array}{c}\text { Waste Type } \\
\text { Liquid/Solid }\end{array}$ & $\begin{array}{c}\text { Pit } \\
\text { Volume } \\
\mathrm{m}^{3}\left(\mathrm{ft}^{3}\right)\end{array}$ & $\begin{array}{c}\text { Maximum } \\
\text { Spill Volume } \\
\text { L (gal) }\end{array}$ & $\begin{array}{c}\text { Onsite } \\
\text { Dose } \\
\text { Sv }\end{array}$ & $\begin{array}{c}\text { Offsite } \\
\text { Dose } \\
\text { Sv }\end{array}$ & $\begin{array}{c}\text { Onsite } \\
\text { Toxicological }\end{array}$ & $\begin{array}{c}\text { Offsite } \\
\text { Toxicological }\end{array}$ \\
\hline Ryan (1999) & NA & NA & $4.1 \mathrm{E}-2$ & $3.7 \mathrm{E}-5$ & $8.1 \mathrm{E}-2$ & $4.2 \mathrm{E}-4$ \\
\hline AWF 67/33 & $\begin{array}{c}91 \\
(3,200)\end{array}$ & $\begin{array}{c}91,000 \\
(24,000)\end{array}$ & $4.1 \mathrm{E}-2$ & $3.5 \mathrm{E}-5$ & $2.3 \mathrm{E}-2$ & $1.2 \mathrm{E}-4$ \\
\hline AWF 95/5 & $\begin{array}{c}390 \\
(14,000)\end{array}$ & $\begin{array}{c}390,000 \\
(100,000)\end{array}$ & $2.7 \mathrm{E}-2$ & $2.3 \mathrm{E}-5$ & $8.1 \mathrm{E}-2$ & $1.4 \mathrm{E}-4$ \\
\hline
\end{tabular}

It is seen from the table above that the dose to the onsite MEI is limiting for a leak of AWF 67/33 into a pit. In contrast, the onsite toxicological dose is limiting for a leak of AWF $95 / 5$ into a pit. These results are due to the assumption that the entire pit air volume is released within one hour and no additional release occurs. The pit volumes above may be compared to the volume of the largest pit in use today, the 241-AP pit with a volume of $74.9 \mathrm{~m}^{3}$ (DOE 1991, Himes 1997). The maximum pit volumes for AWF wastes are significantly larger than $74.9 \mathrm{~m}^{3}$ (241-AP).

It should be noted that the above results for leaks within pits are not sensitive to any particular leak rate assumption. If the spill volume is limited to that represented by the pit volume, then any pit leak rate scenario will have consequences bounded by those reported above. 
TWR-3738, Rev. 1

\subsubsection{Maximum Pit Volumes for Consequences Less than the REGs}

A second set of cases were run to determine the largest pit volume for which the consequences will be within the REGs. The same analysis process using spreadsheets as described in section 5.2.1 was used. The results for all cases are summarized below.

Table 5-5. Maximum Pit Volumes for Consequences within REGs

\begin{tabular}{|c|c|c|c|c|c|c|}
\hline $\begin{array}{c}\text { Waste Type } \\
\text { Liquid/Solid }\end{array}$ & $\begin{array}{c}\text { Pit } \\
\text { Volume } \\
\mathrm{m}^{3}\left(\mathrm{f}^{3}\right)\end{array}$ & $\begin{array}{c}\text { Maximum } \\
\text { Spill Volume } \\
\text { L (gal) }\end{array}$ & $\begin{array}{c}\text { Onsite } \\
\text { Dose } \\
\text { Sv }\end{array}$ & $\begin{array}{c}\text { Offsite } \\
\text { Dose } \\
\text { Sv }\end{array}$ & $\begin{array}{c}\text { Onsite } \\
\text { Toxicological }\end{array}$ & $\begin{array}{c}\text { Offsite } \\
\text { Toxicological }\end{array}$ \\
\hline $\begin{array}{c}\text { SAR-067 } \\
\text { Table 4.3.1-1 }\end{array}$ & NA & NA & $5.0 \mathrm{E}-3$ & $1.0 \mathrm{E}-3$ & 1.0 & 1.0 \\
\hline AWF 67/33 & $\begin{array}{c}11 \\
(3,90)\end{array}$ & $\begin{array}{c}11,000 \\
(2,900)\end{array}$ & $5.0 \mathrm{E}-3$ & $4.2 \mathrm{E}-6$ & $2.8 \mathrm{E}-3$ & $1.5 \mathrm{E}-5$ \\
\hline AWF 95/5 & $\begin{array}{c}72 \\
(2,500)\end{array}$ & $\begin{array}{c}72,000 \\
(19,000)\end{array}$ & $5.0 \mathrm{E}-3$ & $4.2 \mathrm{E}-6$ & $1.5 \mathrm{E}-2$ & $2.5 \mathrm{E}-5$ \\
\hline DST 67/33 & $\begin{array}{c}35 \\
(1,200)\end{array}$ & $\begin{array}{c}35,000 \\
(9,300)\end{array}$ & $5.0 \mathrm{E}-3$ & $4.2 \mathrm{E}-6$ & $8.8 \mathrm{E}-3$ & $4.7 \mathrm{E}-5$ \\
\hline DST 95/5 & $\begin{array}{c}190 \\
(6,700)\end{array}$ & $\begin{array}{c}190,000 \\
(50,000)\end{array}$ & $4.9 \mathrm{E}-3$ & $4.1 \mathrm{E}-6$ & $3.9 \mathrm{E}-2$ & $6.6 \mathrm{E}-5$ \\
\hline SST 67/33 & $\begin{array}{c}78 \\
(2,800)\end{array}$ & $\begin{array}{c}78,000 \\
(21,000)\end{array}$ & $5.0 \mathrm{E}-3$ & $4.4 \mathrm{E}-6$ & $3.0 \mathrm{E}-2$ & $5.6 \mathrm{E}-5$ \\
\hline SST 95/5 & $\begin{array}{c}290 \\
(10,000)\end{array}$ & $\begin{array}{c}290,000 \\
(76,000)\end{array}$ & $5.0 \mathrm{E}-3$ & $4.3 \mathrm{E}-6$ & $6.4 \mathrm{E}-2$ & $7.1 \mathrm{E}-5$ \\
\hline
\end{tabular}

It is seen from the table above that the dose to the onsite MEI is limiting for pit leaks. This is due to the assumption that the entire pit air volume is released within one hour and no additional release occurs. The pit volumes above may be compared to the volume of the largest pit in use today, the 241-AP pit with a volume of $74.9 \mathrm{~m}^{3}$ (DOE 1991, Himes 1997). The maximum pit volumes for AWF 67/33 $\left(11 \mathrm{~m}^{3}\right)$ and DST $67 / 33\left(35 \mathrm{~m}^{3}\right)$ are significantly smaller than $74.9 \mathrm{~m}^{3}$ (241-AP). However, it is possible to transfer the DST waste through lines that do not have pits with volumes larger than $35 \mathrm{~m}^{3}$.

It should be noted that the above results for leaks within pits are not sensitive to any particular leak rate assumption. If the spill volume is limited to that represented by the pit volume, then any pit leak rate scenario will have consequences bounded by those reported above.

\subsection{CONCLUSIONS}

As stated in Section 1.0, two kinds of evaluations are needed to provide a bounding analysis of mitigated waste transfer leak scenarios. One is a spill resulting in a surface pool from 
which gamma-ray exposure and entrainment due to wind occurs. The other is a leak into a confinement structure such as a valve pit which results in the release of aerosols as the pit air is displaced. Acceptable means of mitigation are identified in Section 2.0.

\subsubsection{Leaks in Cleanout Boxes that form a Surface Pool}

For leaks into a COB that form a surface pool, onsite exposure is limited via leak detection and emergency response actions to evacuate onsite personnel within 1 hour. Offsite exposure could increase even after transfer pump shutdown due to continued leakage as long as the transfer pipe continues to drain. The length of pipe which could drain completely yet still have offsite consequences which are bounded by Jones 1998 is reported in Table 5-1 assuming the transfer pipe is 3 -inch schedule 40 pipe. Although the calculation assumed transfer pump shutdown occurred 30 minutes after onset of leakage, this timing is not critical as long as the total volume spilled remains below the spill volume reported in Table 5-1. The primary differences between this analysis and Jones 1998 is the use of a consistent wind speed for both entrainment and atmospheric dispersion as discussed in Section 4.3.3, and the elimination of the splash/splatter source term (see Section 4.3.2). The two wastes that are most restrictive in terms of allowable transfer pipe length in comparison to the Jones (1998) data are AWF 67/33 and DST 67/33 with maximum lengths of 11,000 feet and 55,000 feet, respectively (see Table 5-1). For $20 \mathrm{gpm}$ leaks into a COB, all six waste types have consequences within the REGS for pipe lengths up to 75,000 feet, which corresponds to the total volume that can be drained in a 24-hour period at $20 \mathrm{gpm}$ (see Table 5-3).

\subsubsection{Leaks in Pits}

For the leak in a pit, the pit volume is the critical parameter which defines exposure. Since the pit is not air tight, aerosols can escape via a number of processes. This aerosol release is simplistically assumed to be directly proportional to the pit volume. Leak detection, leak rates and transfer pump shutdown are not critical to onsite and offsite exposure because the entire pit volume is assumed to be displaced in less than an hour. The analysis assumes that the pit does not overflow. This would be true as long as the spill volume remains less then the pit volume. In the event a pit did overflow, a pressurized spray would not be generated due to the uplifting of the cover blocks as discussed in Section 4.3.2.2. Also, aerosol generation through a splash and splatter mechanism would not be expected due to the "near grade" top of the pit and geometry not conducive to a free fall spill. This is also discussed in Section 4.3.2.2.

The Safety Basis that provides the current Authorization Basis for AWF wastes is provided in FSAR Transition Spray Leak Analysis, Rev. 0, HNF-5147 (Ryan 1999). The AWF 67/33 and AWF 95/5 waste are at the limits in Ryan (1999) for pit volumes of 91 and $390 \mathrm{~m}^{3}$, respectively, which are larger than the largest pit $\left(74.9 \mathrm{~m}^{3}\right)$. These results are provided in Table $5-4$.

The DST 95/5, SST 67/33, and SST 95/5 wastes are all within the REGs for leaks in pits larger than $74.9 \mathrm{~m}^{3}$. The DST $67 / 33$ waste is within the REGs for a pit volume of $35 \mathrm{~m}^{3}$. The AWF $67 / 33$ waste is within the REG limits for a pit volume of $11 \mathrm{~m}^{3}$. Leaks into pits with consequences which are bounded by the REGs are reported in Table 5-5. 
In 4 out of 6 cases (AWF 67/33, AWF 95/5, DST 67/33, and SST 67/33) the bounding pit volume is less than the bounding surface pool volume. Hence, this same bounding surface pool volume leaked into the bounding pit would result in an overflow. However, this would not affect onsite consequences because assuming a 20 gpm leak even the smallest bounding pit $\left(11 \mathrm{~m}^{3}\right)$ would take longer than 2 hours to fill, by which time the onsite worker would be evacuated. 


\subsection{REFERENCES}

ARH-2977 RD, 1974, Report On the Cleamup Activities Following the 24I-S Tank Farm Contamination Occurrence at the Hanford Reservation, Atlantic Richfield Hanford Company, Richland, Washington.

Cowherd, Jr., C., et. al, 1985, Rapid Assessment of Exposure to Particulate Emissions from Surface Contamination Sites, EPA/600/8-85/002, United States Environmental Protection Agency, Washington, D.C.

DOE, 1991, Double-Shell Tank System Dangerous Waste Permit Application, DOE-RL90-39, Rev. 0, U. S. Department Of Energy, Richland, Washington.

DOE, 1994, Airborne Release Fractions/Rates and Respirable Fraction for Nonreactor Nuclear Facilities, DOE-HDBK-3010-94, U. S. Department Of Energy, Washington D.C.

Hall, B. W., 1996a, Calculation Notes for Surface Leak Resulting in Pool, TWRS FSAR Accident Analysis, WHC-SD-WM-CN-049, Rev. 0, Westinghouse Hanford Co., Richland, Washington.

Hall, B. W., 1996b, Calculation Notes for Subsurface Leak Resulting in Pool, TWRS FSAR Accident Analysis, WHC-SD-WM-CN-057, Rev. 0, Westinghouse Hanford Co., Richland, Washington.

Hall, B. W., 1996c, Calculation Notes for in Support of TWRS FSAR Spray Leak Accident Analysis, WHC-SD-WM-CN-048, Rev. 0, Westinghouse Hanford Co., Richland, Washington.

Hanna, Steven R., 1982, Handbook on Atmospheric Diffusion, DOE/TIC-1 1223, Technical Information Center, U. S. Department of Energy.

Hey, B. E., 1999a, Refined Consequence Analysis of Subsurface Leak from TWRS Facilities that Result in a Surface Pool, TWR-3958, Fluor Daniel Northwest, Richland, Washington

Hey, B. E., 1999b, Mitigated Transfer Line Leaks that Result in Surface Pool, TWR-3738, Rev. 0 , Fluor Daniel Northwest, Richland, Washington

Himes, D. A., 1997, Radiological and Toxicological Consequences of a Worst-Case Spray Leak Related to Project W-320, HNF-SD-WM-CN-102, Rev. 0, Fluor Daniel Northwest Inc., Richland, Washington.

HNF, 1997, Calculation for Supplemental Covers On Structures Smaller Than 24I-A-A, HNF-2329, Fluor Daniel Hanford, Inc., Richland, Washington. 
HNF, 1998a, Tank Waste Remediation System Technical Safety Requirements, HNF-SD-WMTSR-006, Rev. 0-P, Fluor Daniel Hanford, Inc., Richland, Washington.

HNF, 1998b, Justification for Continued Operation of Transfer Lines Having Structures with Less Volume Than the 241-A-A Valve Pit, HNF-2296, Fluor Daniel Hanford, Inc., Richland, Washington.

HNF, 1998c, Hydraulic Calculations for Cross Site Transfer System and Selected

Physically Connected Routes, HNF-3612, Fluor Daniel Hanford, Inc., Richland, Washington.

HNF 1999, Tank Waste Remediation System Final Safety Analysis Report, HNF-SD-WMSAR-067, Revision 1, Fluor Daniel Hanford, Inc., Richland, WA.

Jones, G. L., 1998, Calculation Notes for Surface Leak Resulting in Pool, TWRS FSAR Accident Analysis, WHC-SD-WM-CN-049, Rev. 0-B, Duke Engineering Services Hanford, Richland, Washington.

Ryan, G. W., 1999, FSAR Transition Spray Leak Analysis, Rev. 0, HNF-5147, Fluor Daniel Northwest, Inc., Richland, Washington.

Van Keuren, J. C. 1996a, Tank Waste Compositions and Atmospheric Dispersion Coefficients for Use In Safety Analysis Consequence Assessments, WHC-SD-WMSARR-016, Rev. 2, Westinghouse Hanford Co., Richland, Washington.

Van Keuren, J. C. 1996b, Toxic Chemical Considerations for Tank Farm Releases, WHCSD-WM-SARR-011, Rev. 2, Westinghouse Hanford Co., Richland, Washington.

Van Keuren, J. C., 1998, Revised Spray Leak Calculations for Project W-058, HNF-2542, Rev. 0, Fluor Daniel Northwest, Inc., Richland, Washington.

Van Vleet, R. J., 1997, Consequences of a Radioactive Surface Pool Resulting from Waste Transfer Operations between Tanks 24I-C-106 and 241-AY-102, WHC-SD-WMCN-110, Rev. 0, Westinghouse Hanford Co., Richland Washington. 
TWR-3738, Rev. 1

This page intentionally left blank. 
TWR-3738, Rev. 1

\section{APPENDIX A - Calculation of Volumetric Air Exchange Rate for COB}

An approximate air exchange rate is calculated for a supplementary cover having the dimensions shown in Figure 1. The premise of this calculation is that wind will blow in an opening on one side of the enclosure, mix thoroughly with the air inside the enclosure, and exit the opposite side through a similar opening. The opening shown in Figure 1 has an area $\mathrm{A}$ of $0.0277 \mathrm{~m}^{2}\left(\sim 43 \mathrm{in}^{2}\right)$ and the enclosure volume $\mathrm{V}$ is $1.2 \mathrm{~m}^{3}$. 1982):

An approximate ground level wind speed is calculated using a power law formula (Hanna

$$
\mathrm{u}=\mathrm{u}_{10}(\mathrm{z} / 10)^{\mathrm{p}}
$$

where $z$ is height in meters and $u_{10}$ is the observed wind speed at a height of $10 \mathrm{~m}$. The power factor $\mathrm{p}$ is taken to represent class $\mathrm{F}$ wind speed for rural conditions and is assigned a value of 0.55 . Using this formula for an observed $10 \mathrm{~m}$ wind speed of $0.89 \mathrm{~m} / \mathrm{s}$, a wind speed of 0.0707 $\mathrm{m} / \mathrm{s}$ is calculated for height of $0.1 \mathrm{~m}$. This should conservatively represent the wind speed at the face of the enclosure opening which is approximately one inch above the ground.

The flow rate through the enclosure under these conditions is given by the formula:

$$
\begin{aligned}
\text { w } & =\mathbf{u A} \\
& =(0.0707 \mathrm{~m} / \mathrm{s})\left(0.0277 \mathrm{~m}^{2}\right) \\
& =0.00196 \mathrm{~m}^{3} / \mathrm{s}
\end{aligned}
$$

The volume exchange rate is then:

$$
\begin{aligned}
\mathrm{R} & =\mathrm{w} / \mathrm{V} \\
& =\left(0.00196 \mathrm{~m}^{3} / \mathrm{s}\right) /\left(1.2 \mathrm{~m}^{3}\right) \\
& =0.00163 \mathrm{vol} / \mathrm{s} \\
& =5.9 \mathrm{vol} / \mathrm{hr}
\end{aligned}
$$


TWR-3738, Rev. 1

This page intentionally left blank. 


\section{APPENDIX B - Spreadsheet Consequence Calculations}

The following pages include spreadsheet results representing various waste compositions, pit volumes and transfer line lengths. Unit liter doses, toxic sum of fractions, and Bremsstrahlung gamma-ray spectra for Sr-90 were taken from Van Keuren (1996a, 1996b). Onsite exposures due to material entrainment from a surface pool use the $\chi / Q$ based on a wind speed of $9.8 \mathrm{~m} / \mathrm{s}$ and Class D conditions for conservatism in the aerosol entrained by wind acting on the surface pool. The release rate per unit area is based on a correlation that is a function of wind speed and pool diameter (for the fetch). Exposures due to material released from a Supplemental Cover on the Cleanout Box use for conservatism a plume meander corrected $\chi / Q$ for a wind speed of $1 \mathrm{~m} / \mathrm{s}$ and Class $\mathrm{F}$ conditions.

Gamma-ray shine doses are derived using the ratio of the pool volume to the $1,200 \mathrm{gal}$ spill assumed in the reference case. The Microshield ${ }^{T M}$ and Microskyshine ${ }^{T M}$ output files for the reference case are provided in Appendix C. This is appropriate since the onsite MEI distance is far enough (i.e., $100 \mathrm{~m}$ ) to cause the relationship between source quantity and dose to be approximately linear. Gamma-ray shine doses are also ratioed by the Cs- 137 pool inventory against the base case inventory since $\mathrm{Cs}-137$ dominates the gamma-ray shine dose. 
TWR-3738, Rev. 1

This page intentionally left blank.

B-2 
TWR-3738, Rev. 1

\section{7/33 AWF Waste and 20 gpm Leak}

File:TWR3738Rev1/3738R1AWF67

\begin{tabular}{|c|c|c|}
\hline Waste Type & $\begin{array}{c}\text { Inhalation } \\
(\mathrm{Sv} / \mathrm{L})\end{array}$ & $\begin{array}{c}\text { Tngestion } \\
\left(\text { Sv- } \mathrm{m}^{\wedge} 3 / \mathrm{s}\right. \\
\mathrm{L})\end{array}$ \\
\hline AWF Liquids & $1.4 \mathrm{E}+03$ & $9.2 \mathrm{E}-02$ \\
\hline AWF Solids & $1.7 E+06$ & $8.1 E+00$ \\
\hline 67/33 Composite & $5.6 \mathrm{E}+05$ & $2.7 \mathrm{E}+00$ \\
\hline
\end{tabular}

AWF Continuous Release SOF Multipliers ( $/ \mathrm{L}$ ) (same as DST)

\begin{tabular}{|c|c|c|c|c|c|c|}
\hline \multirow[b]{2}{*}{ Waste Type } & \multicolumn{2}{|c|}{ Anticipated Frequency } & \multicolumn{2}{|c|}{ Unlikely Frequency } & \multicolumn{2}{|c|}{$\begin{array}{c}\text { Extremely Unlikely } \\
\text { Frequency }\end{array}$} \\
\hline & Onsite & Offsite & Onsite & Offsite & Onsite & Offsite \\
\hline AWF Liquids & $1.0 \mathrm{E}+04$ & $8.4 \mathrm{E}+00$ & $7.5 E+02$ & $8.4 E+00$ & 2.1E+02 & $6.2 \mathrm{E}-01$ \\
\hline AWF Solids & $1.8 \mathrm{E}+04$ & $1.9 E+02$ & $3.3 E+03$ & $1.5 \mathrm{E}+01$ & $6.3 E+02$ & $2.8 \mathrm{E}+00$ \\
\hline $67 / 33$ Composite & $1.3 E+04$ & $6.8 \mathrm{E}+01$ & $1.6 \mathrm{E}+03$ & 1.1E+01 & $3.5 E+02$ & 1. $3 E+00$ \\
\hline
\end{tabular}

Atmospheric Dispersion Coefficients (X/Q)

\begin{tabular}{|l|c|c|}
\hline & Onsite & Offsite \\
\hline $95 \%, 9.8 \mathrm{~m} / \mathrm{s}$, TWR-3958 & $7.57 \mathrm{E}-04$ & $4.92 \mathrm{E}-07$ \\
\hline $99.5 \%, 1 \mathrm{~m} / \mathrm{s}$, TWR-3738 & $3.41 \mathrm{E}-02$ & $1.39 \mathrm{E}-05$ \\
\hline
\end{tabular}

Breathing Rates $(\mathrm{m} 3 / \mathrm{s})$

light activity

24-hr average
3.3E-04

3.3E-04 Note LA rate
Waste Cs-137 Activity (Bq/L)

\begin{tabular}{|l|l|}
\hline Cs-137 Activity for this waste & $9.13 \mathrm{E}+10$ \\
\hline
\end{tabular}

\begin{tabular}{ll}
\hline Cs-137 Activity, Ref. DST 95/5 & $5.90 \mathrm{E}+10$ \\
\hline
\end{tabular}

\begin{tabular}{lll}
\hline Gamma Multiplier for this waste & $1.55 \mathrm{E}+00$ \\
\hline
\end{tabular}

Logarithmic Interpolated X/Q 2.12E-05

Time $(\mathrm{hr})=\quad 4 \quad 1.24 \mathrm{E}-07$

$\mathrm{X} / \mathrm{Q}=\mathrm{I} 39 \mathrm{E} 05$ 
TWR-3738, Rev. 1

\section{7/33 AWF Waste and 20 gpm Leak}

Pipe Length (feet)

$11,200.0$

File: TWR3738Rev1/3738R1AWF67

Source Term

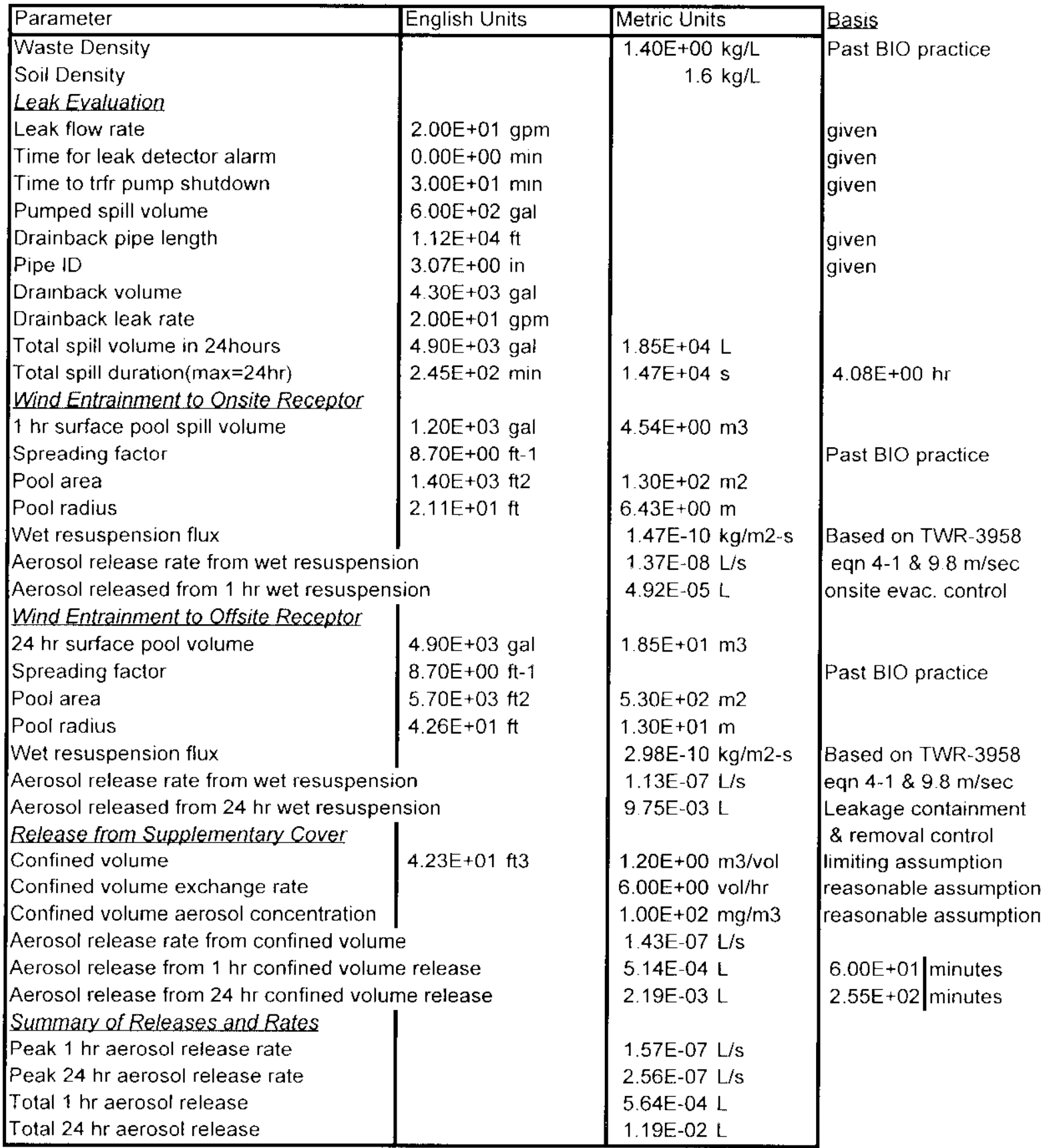


TWR-3738, Rev. 1

\section{7/33 AWF Waste and $20 \mathrm{gpm}$ Leak}

One hour leak quantity = 24 hour leak quantity =

Transfer Line Length =
$1,200 \mathrm{gal}$

$4,901 \mathrm{gal}$

$11,200 \mathrm{ft}$

Line vol
Total time $4.08 \mathrm{E}+00$ hours $2.45 \mathrm{E}+02$ minutes

2.1 miles

4301 gallons

Radiological Consequences

\begin{tabular}{|l|c|c|}
\hline Pathway & Onsite MEl EDE (Sv) & Offsite MEI EDE (Sv) \\
\hline Inhalation & $3.26 \mathrm{E}-03$ & $6.51 \mathrm{E}-06$ \\
Ingestion & NA & $9.60 \mathrm{E}-08$ \\
Gamma-ray & $102 \mathrm{E}-03$ & $\mathrm{NA}$ \\
Total & $4.28 \mathrm{E}-03$ & $6.60 \mathrm{E}-06$ \\
Anticipated Guideline & $5.00 \mathrm{E}-03$ & $1.00 \mathrm{E}-03$ \\
\hline
\end{tabular}

Toxicological Consequences

\begin{tabular}{|l|c|l|c|l|}
\hline Pathway & Onsite MEI (SOF) & \multicolumn{2}{l|}{ Offsite MEI (SOF) } \\
\hline Inhalation & $1.98 \mathrm{E}-03$ & & $1.75 \mathrm{E}-05$ & \\
\hline Guideline & $1.00 \mathrm{E}+00$ & & $1.00 \mathrm{E}+00$ & \\
\hline
\end{tabular}

File:TWR3738Rev1/3738R1AWF67

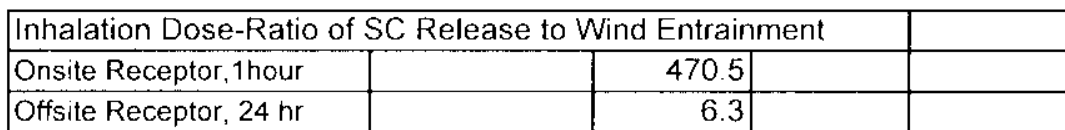


TWR-3738, Rev. 1

67/33 AWF Waste and $20 \mathrm{gpm}$ Leak

Summary of Results Pipe Length (feet) $\quad 11.200 .0$

\begin{tabular}{|c|c|c|c|c|}
\hline Consequences & Receptor & Conseq & Guideline & Rev 0-B ${ }^{\star}$ \\
\hline Radiological & Onsite & $4.3 \mathrm{E}-03$ & $5.0 \mathrm{E}-03$ & $5.1 \mathrm{E}-03$ \\
& Offsite & $6.6 \mathrm{E}-06$ & $1.0 \mathrm{E}-03$ & $6.6 \mathrm{E}-06$ \\
\hline Toxicological & Onsite & $2.0 \mathrm{E}-03$ & $1.0 \mathrm{E}+00$ & $1.4 \mathrm{E}-01$ \\
\hline & Offsite & $1.7 \mathrm{E}-05$ & $1.0 \mathrm{E}+00$ & $7.5 \mathrm{E}-04$ \\
\hline
\end{tabular}

File TWR3738Rev1/3738R1AWF67

\begin{tabular}{|c|c|c|c|c|c|c|c|}
\hline \multicolumn{8}{|c|}{ Radiological Consequences } \\
\hline & \multicolumn{7}{|c|}{ Source Terms by Mechanism(L) } \\
\hline & SupCover & WetResus & Gamma & $\mathrm{X} / \mathrm{Q}(\mathrm{s} / \mathrm{m} 3)$ & $\mathrm{BR}(\mathrm{m} 3 / \mathrm{s})$ & ÚLD(Sv/L) & Dose(Sv) \\
\hline Inhalation & & $4.92 \mathrm{E}-05$ & & $7.57 \mathrm{E}-04$ & $3.30 \mathrm{E}-04$ & $5.62 \mathrm{E}+05$ & $6.91 \mathrm{E}-06$ \\
\hline & $5.14 \mathrm{E}-04$ & & & $3.41 E-02$ & $3.30 \mathrm{E}-04$ & $5.62 \mathrm{E}+05$ & $3.25 \mathrm{E}-03$ \\
\hline Gamma* & & & $1.02 \mathrm{E}-03$ & & & & $1.02 \mathrm{E}-03$ \\
\hline Total & & & & & & & $4.28 \mathrm{E}-03$ \\
\hline Inhalation & & $9.75 \mathrm{E}-03$ & NA & 4.92E-07 & $3.30 \mathrm{E}-04$ & $5.62 \mathrm{E}+05$ & $8.90 \mathrm{E}-07$ \\
\hline & $2.19 E-03$ & & NA & 1.39E-05 & $3.30 \mathrm{E}-04$ & $5.62 \mathrm{E}+05$ & $5.62 \mathrm{E}-06$ \\
\hline Ingestion & & $9.75 \mathrm{E}-03$ & & $4.92 \mathrm{E}-07$ & & $2.73 E+00$ & $1.31 \mathrm{E}-08$ \\
\hline & $2.19 \mathrm{E}-03$ & & & $1.39 \mathrm{E}-05$ & & $2.73 \mathrm{E}+00$ & $8.29 E-08$ \\
\hline Total & & & & & & & $6.60 \mathrm{E}-06$ \\
\hline
\end{tabular}

\begin{tabular}{|l|r|r|r|r|r|r|r|}
\hline Toxicological Consequences & & & & & & \\
\hline & Initial Rates (L/s) & 24 hour Rates (L/s) & & & \\
\hline Location & SupCover & WetResus & SupCover & WetRes us & Rate (L/s) & SOF Mult & SOF \\
\hline Onsite & $1.43 \mathrm{E}-07$ & $1.37 \mathrm{E}-08$ & & & $1.57 \mathrm{E}-07$ & $1.26 \mathrm{E}+04$ & $1.98 \mathrm{E}-03$ \\
\hline & & & & & & & \\
\hline Offsite & $1.43 \mathrm{E}-07$ & $1.37 \mathrm{E}-08$ & $1.43 \mathrm{E}-07$ & $1.13 \mathrm{E}-07$ & $2.56 \mathrm{E}-07$ & $6.83 \mathrm{E}+01$ & $1.75 \mathrm{E}-05$ \\
\hline
\end{tabular}

File:TWR3738Rev1/3738R1AWF67 
TWR-3738, Rev. 1

\section{5/5 AWF Waste and $20 \mathrm{gpm}$ Leak}

File TWR3738Rev1/3738R1AWF95

AWF Radıologıcal Unit Liter Doses

\begin{tabular}{|l|c|c|}
\hline Waste Type & $\begin{array}{c}\text { Inhalation } \\
(\mathrm{S} v / \mathrm{L})\end{array}$ & $\begin{array}{c}\text { Ingestion } \\
\left(\mathrm{Sv}-\mathrm{m}^{\wedge} 3 / \mathrm{s}\right. \\
\mathrm{L})\end{array}$ \\
\hline AWF Liquids & $1.4 \mathrm{E}+03$ & $9.2 \mathrm{E}-02$ \\
\hline AWF Solids & $1.7 \mathrm{E}+06$ & $8.1 \mathrm{E}+00$ \\
\hline $95 / 5$ Composite & $8.6 \mathrm{E}+04$ & $4.9 \mathrm{E}-01$ \\
\hline
\end{tabular}

AWF Continuous Release SOF Multipliers (s/L)

\begin{tabular}{|l|cc|cc|cc|}
\hline & \multicolumn{2}{|c|}{ Anticipated Frequency } & \multicolumn{2}{c|}{ Unlikely Frequency } & \multicolumn{2}{c|}{$\begin{array}{c}\text { Extremely Unlikely } \\
\text { Frequency }\end{array}$} \\
& Onsite & Offsite & Onsite & Offsite & Onsite & Offsite \\
\hline AWF Liquids & $1.0 \mathrm{E}+04$ & $8.4 \mathrm{E}+00$ & $7.5 \mathrm{E}+02$ & $8.4 \mathrm{E}+00$ & $2.1 \mathrm{E}+02$ & $6.2 \mathrm{E}-01$ \\
AWF Solids & $1.8 \mathrm{E}+04$ & $1.9 \mathrm{E}+02$ & $3.3 \mathrm{E}+03$ & $1.5 \mathrm{E}+01$ & $6.3 \mathrm{E}+02$ & $2.8 \mathrm{E}+00$ \\
$95 / 5$ Composite & $1.0 \mathrm{E}+04$ & $1.7 \mathrm{E}+01$ & $8.8 \mathrm{E}+02$ & $8.7 \mathrm{E}+00$ & $2.3 \mathrm{E}+02$ & $7.3 \mathrm{E}-01$ \\
\hline
\end{tabular}

Atmospheric Dispersion Coefficients (X/Q)

\begin{tabular}{|c|c|c|}
\hline & Onsite & Offsite \\
\hline $95 \%, 9.8 \mathrm{~m} / \mathrm{s}$, TWR-3958 & $7.57 \mathrm{E}-04$ & $4.92 \mathrm{E}-07$ \\
\hline $99.5 \%, 1 \mathrm{~m} / \mathrm{s}$, TWR-3738 & $3.41 \mathrm{E}-02$ & $7.07 \mathrm{E}-06$ \\
\hline
\end{tabular}

Breathing Rates (m3/s)

iight activity

24-hr average
3.3E-04

3.3E-04
Waste Cs-137 Activity (Bq/L)

Cs-137 Activity for this waste Cs-137 Activity, Ref. DST 95/5 $8.85 E+10$ Gamma Multiplier for this waste $5.90 \mathrm{E}+10$ $1.50 \mathrm{E}+00$

Logarithmic Interpolated Chi/Q

2.12E-05

Time $(\mathrm{hr})=$ 12

1.24E-07 
TWR-3738, Rev. 1

95/5 AWF Waste and $20 \mathrm{gpm}$ Leak

Pipe Length (feet)

$75,000.0$

File:TWR3738Rev1/3738R1AWF95

Source Term

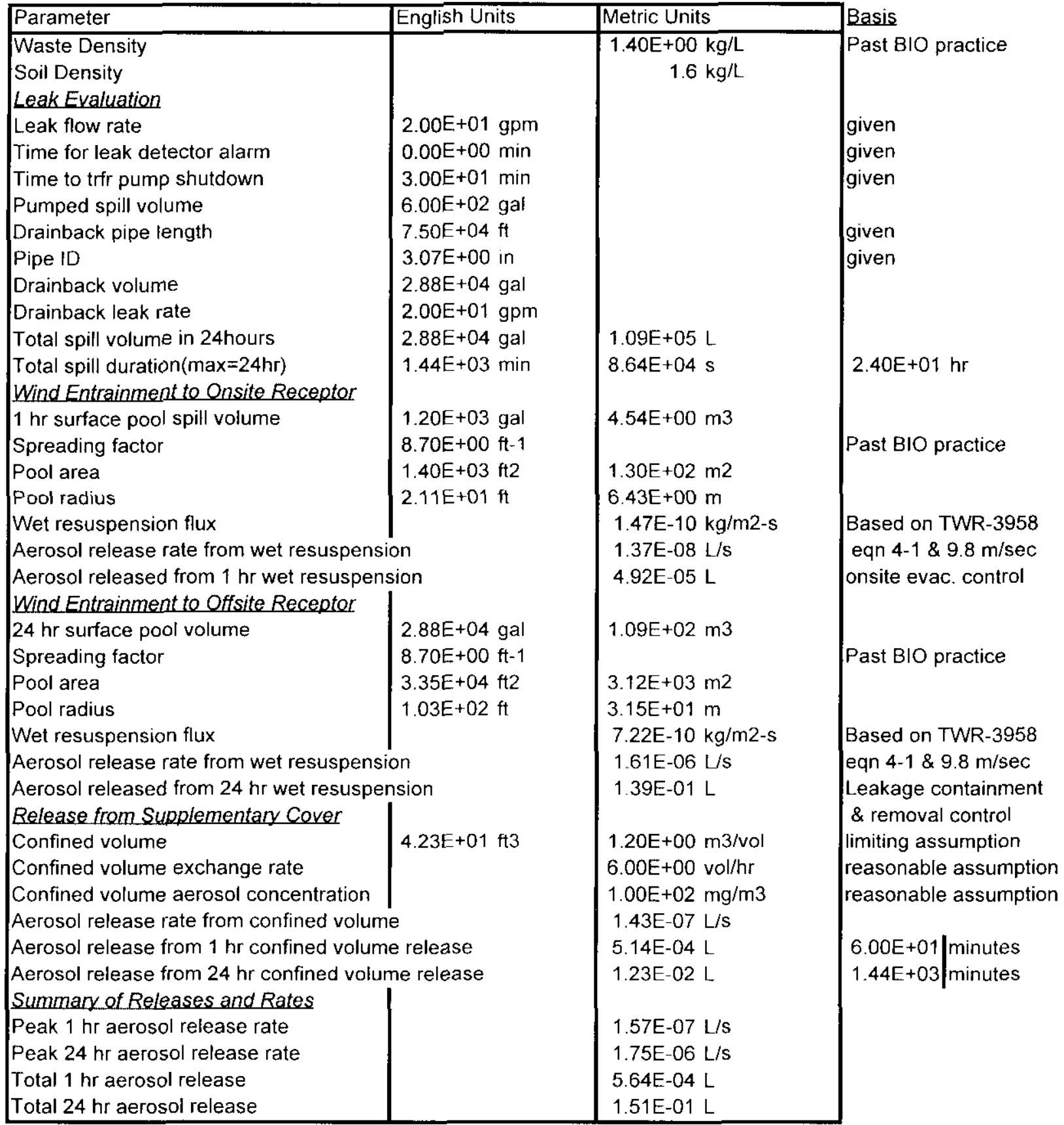


TWR-3738, Rev. 1

95/5 AWF Waste and 20 gpm Leak

One hour leak quantity =

$1,200 \mathrm{gal}$

24 hour leak quantity $=$

$28,800 \mathrm{gal}$

Transfer Line Length =

$75,000 \mathrm{ft}$
Total time $\quad 2.40 E+01$ hours
$1.44 \mathrm{E}+03$ minutes

14.2 miles

28801 gallons

$12 \mathrm{hr}$ for $\mathrm{X} / \mathrm{Q}$

Radiological Consequences

\begin{tabular}{|l|c|c|}
\hline Pathway & Onsite MEI EDE (Sv) & Offsite MEl EDE (Sv) \\
\hline Inhalation & $5.01 \mathrm{E}-04$ & $4.43 \mathrm{E}-06$ \\
Ingestion & $\mathrm{NA}$ & $7.66 \mathrm{E}-08$ \\
Gamma-ray & $9.89 \mathrm{E}-04$ & NA \\
Total & $1.49 \mathrm{E}-03$ & $4.51 \mathrm{E}-06$ \\
Anticipated Guideline & $5.00 \mathrm{E}-03$ & $1.00 \mathrm{E}-03$ \\
\hline
\end{tabular}

Toxicological Consequences

\begin{tabular}{|l|c|l|l|l|}
\hline Pathway & \multicolumn{2}{|l|}{ Onsite MEI (SOF) } & \multicolumn{2}{|l|}{ Offsite MEI (SOF) } \\
\hline Inhalation & $1.63 \mathrm{E}-03$ & & $3.06 \mathrm{E}-05$ & \\
\hline Guideline & $1.00 \mathrm{E}+00$ & & $1.00 \mathrm{E}+00$ & \\
\hline
\end{tabular}

File:TWR3738Rev1/3738R1AWF95

Inhalation Dose-Ratio of SC Release to Wind Entrainment

Onsite Receptor, 1hour

470.5

Offsite Receptor, $24 \mathrm{hr}$

1.3


TWR-3738, Rev. 1

95/5 AWF Waste and $20 \mathrm{gpm}$ Leak Summary of Results

Pipe Length (feet) $\quad 75,000.0$

\begin{tabular}{|c|c|c|c|c|}
\hline Consequences & Receptor & Conseq. & Guideline & Rev 0-B* \\
\hline Radiological & Onsite & $1.49 \mathrm{E}-03$ & $5.00 \mathrm{E}-03$ & $5.10 \mathrm{E}-03$ \\
\hline & Offsite & $4.51 \mathrm{E}-06$ & $1.00 \mathrm{E}-03$ & $6.60 \mathrm{E}-06$ \\
\hline Toxicological & Onsite & $1.63 \mathrm{E}-03$ & $1.00 \mathrm{E}+00$ & $1.40 \mathrm{E}-01$ \\
\hline & Offsite & $3.06 \mathrm{E}-05$ & $1.00 \mathrm{E}+00$ & $7.50 \mathrm{E}-04$ \\
\hline
\end{tabular}

File:TWR3738Rev1/3738R1AWF95

\begin{tabular}{|r|r|r|r|r|r|r|r|}
\hline Radiological Consequences & & & & & & \\
\hline & Source Terms by Mechanism(L) & & & & \\
\hline & SupCover & WetResus & Gamma & X/Q(s/m3) & BR(m3/s) & ULD(Sv/L) & Dose(Sv) \\
\hline Onsite rinhalation & & $4.92 \mathrm{E}-05$ & & $7.57 \mathrm{E}-04$ & $3.30 \mathrm{E}-04$ & $8.63 \mathrm{E}+04$ & $1.06 \mathrm{E}-06$ \\
\hline & $5.14 \mathrm{E}-04$ & & & $3.41 \mathrm{E}-02$ & $3.30 \mathrm{E}-04$ & $8.63 \mathrm{E}+04$ & $5.00 \mathrm{E}-04$ \\
\hline Gamma & & & $9.89 \mathrm{E}-04$ & & & & $9.89 \mathrm{E}-04$ \\
\hline Total & & & & & & & $1.49 \mathrm{E}-03$ \\
\hline Offsite & & $1.39 \mathrm{E}-01$ & NA & $4.92 \mathrm{E}-07$ & $3.30 \mathrm{E}-04$ & $8.63 \mathrm{E}+04$ & $1.95 \mathrm{E}-06$ \\
\hline Inhalation & $1.23 \mathrm{E}-02$ & & NA & $7.07 \mathrm{E}-06$ & $3.30 \mathrm{E}-04$ & $8.63 \mathrm{E}+04$ & $2.48 \mathrm{E}-06$ \\
\hline & & $1.39 \mathrm{E}-01$ & & $4.92 \mathrm{E}-07$ & & $4.92 \mathrm{E}-01$ & $3.37 \mathrm{E}-08$ \\
\hline Ingestion & $1.23 \mathrm{E}-02$ & & & $7.07 \mathrm{E}-06$ & & $4.92 \mathrm{E}-01$ & $4.29 \mathrm{E}-08$ \\
\hline & & & & & & & $4.51 \mathrm{E}-06$ \\
\hline Total & & &
\end{tabular}

${ }^{*}$ Gamma $=($ Shine+Skyshine for Reference Leak) $\times($ Ratio of Leak Volumes) $\times$ (Ratio of Cs137 Activities)

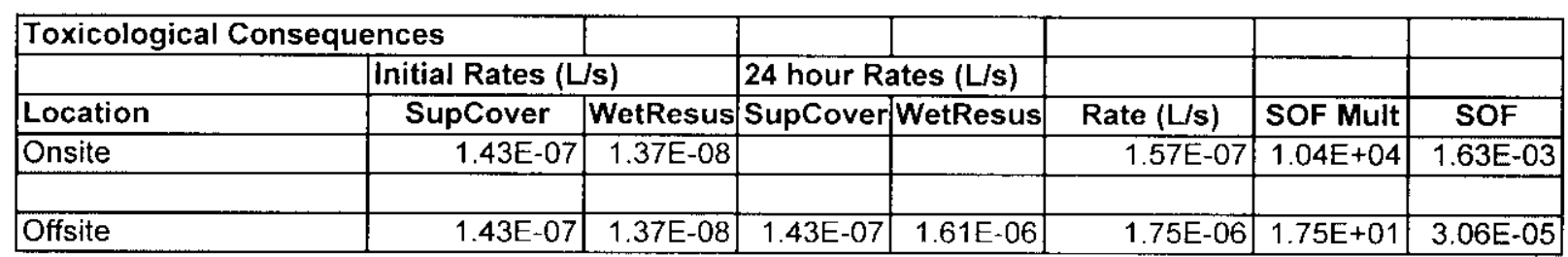

File:TWR3738Rev1/3738R1AWF95 
TWR-3738, Rev. 1

\section{7/33 DST Waste $20 \mathrm{gpm}$ Leak}

File' TWR3738Rev1/3738R1DST67

DST Radiological Unit Liter Doses

\begin{tabular}{|l|cc|}
\hline \multicolumn{1}{|c|}{$\begin{array}{c}\text { Inhalation } \\
\text { Waste Type }\end{array}$} & $\begin{array}{c}\text { Ingestion } \\
\left(\text { Sv- } \mathrm{m}^{\wedge} 3 / \mathrm{s}-\right.\end{array}$ \\
\hline DST Liquids & $6.1 \mathrm{E}+03$ & $6.8 \mathrm{E}-02$ \\
DST Solids & $5.3 \mathrm{E}+05$ & $4.8 \mathrm{E}-01$ \\
67/33 Composite & $1.8 \mathrm{E}+05$ & $2.0 \mathrm{E}-01$ \\
\hline
\end{tabular}

DST Continuous Release SOF Multipliers (s/L)

\begin{tabular}{|c|c|c|c|c|c|c|}
\hline \multirow[b]{2}{*}{ Waste Type } & \multicolumn{2}{|c|}{ Anticipated Frequency } & \multicolumn{2}{|c|}{ Unlikely Frequency } & \multicolumn{2}{|c|}{$\begin{array}{l}\text { Extremely Unlikely } \\
\text { Frequency }\end{array}$} \\
\hline & Onsite & Offsite & Onsite & Offsite & Onsite & Offsite \\
\hline DST Liquids & $1.0 E+04$ & $8.4 \mathrm{E}+00$ & $7.5 \mathrm{E}+02$ & $8.4 \mathrm{E}+00$ & $2.1 E+02$ & $6.2 E-01$ \\
\hline DST Solids & $1.8 E+04$ & $1.9 E+02$ & $3.3 E+03$ & $1.5 E+01$ & $6.3 E+02$ & $2.8 E+00$ \\
\hline 67/33 Composite & $1.3 E+04$ & $6.8 \mathrm{E}+01$ & $1.6 \mathrm{E}+03$ & 1.1E+01 & $3.5 E+02$ & $1.3 E+00$ \\
\hline
\end{tabular}

Atmospheric Dispersion Coefficients (X/Q)

\begin{tabular}{|c|c|c|}
\hline & Onsite & Offsite \\
\hline $95 \%, 9.8 \mathrm{~m} / \mathrm{s}$, TWR-3958 & $7.57 \mathrm{E}-04$ & $4.92 \mathrm{E}-07$ \\
\hline $99.5 \%, 1 \mathrm{~m} / \mathrm{s}$, TWR-3738 & $3.41 \mathrm{E}-02$ & $7.07 \mathrm{E}-06$ \\
\hline
\end{tabular}

Breathing Rates (m3/s)

\begin{tabular}{|l|c|}
\hline light activity & $3.3 \mathrm{E}-04$ \\
$24-\mathrm{hr}$ average & $3.3 \mathrm{E}-04$ \\
\hline
\end{tabular}

Waste Cs-137 Activity (Bq/L)

Cs-137 Activity for this waste

Cs-137 Activity, Ref. DST 95/5

$5.90 \mathrm{E}+10$

Gamma Multiplier for this waste

$5.90 \mathrm{E}+10$

$1.00 \mathrm{E}+00$

\begin{tabular}{|c|c|c|}
\hline Logarithmi & polated $X / Q$ & $2.12 \mathrm{E}-05$ \\
\hline Time $(\mathrm{hr})=$ & 12 & $1.24 \mathrm{E}-07$ \\
\hline
\end{tabular}


TWR-3738, Rev. 1

\section{7/33 DST Waste 20 gpm Leak}

Pipe Length (feet) $\quad 55,000.0$

File:TWR3738Rev1/3738R1DST67

Source Term

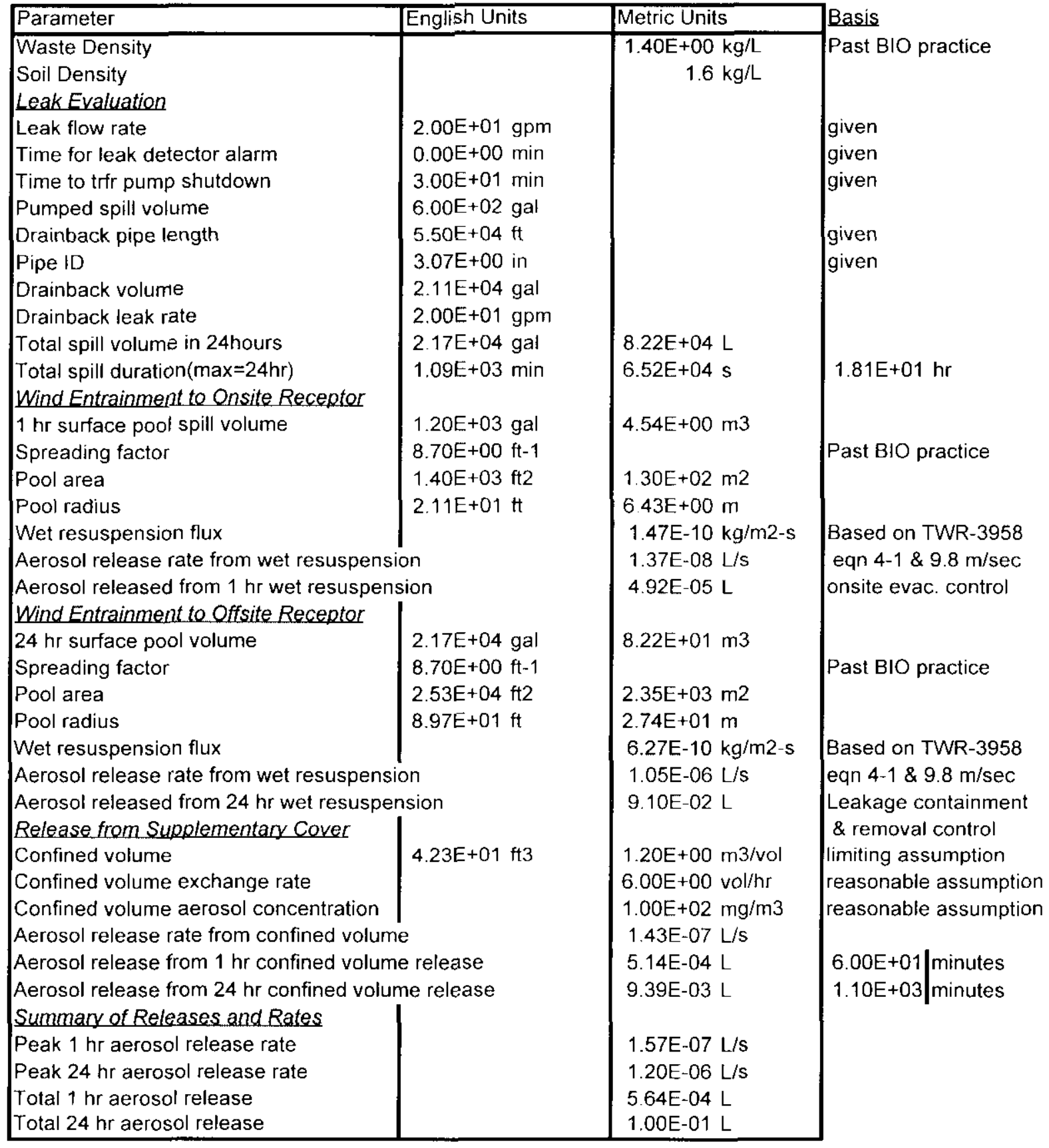


TWR-3738, Rev. 1

\section{7/33 DST Waste $20 \mathrm{gpm}$ Leak}

One hour leak quantity $=$

24 hour leak quantity =

Transfer Line Length $=$
$1,200 \mathrm{gal}$

21,720 gal

$55,000 \mathrm{ft}$

Line vol.

\author{
Total time $1.81 \mathrm{E}+01$ hours \\ $1.09 \mathrm{E}+03$ minutes
}

10.4 miles 21120 gallons

Radiological Consequences

\begin{tabular}{|l|c|c|}
\hline Pathway & Onsite MEI EDE (Sv) & Offsite MEI EDE (Sv) \\
\hline Inhalation & $1.04 \mathrm{E}-03$ & $6.57 \mathrm{E}-06$ \\
Ingestion & $\mathrm{NA}$ & $2.27 \mathrm{E}-08$ \\
Gamma-ray & $6.59 \mathrm{E}-04$ & $\mathrm{NA}$ \\
Total & $1.70 \mathrm{E}-03$ & $6.59 \mathrm{E}-06$ \\
Anticipated Guideline & $5.00 \mathrm{E}-03$ & $1.00 \mathrm{E}-03$ \\
\hline
\end{tabular}

Toxicological Consequences

\begin{tabular}{|l|c|l|c|c|}
\hline Pathway & Onsite MEI (SOF) & \multicolumn{2}{|c|}{ Offsite MEI (SOF) } \\
\hline Inhalation & $1.98 \mathrm{E}-03$ & & $8.17 \mathrm{E}-05$ & \\
\hline Guideline & $1.00 \mathrm{E}+00$ & & $1.00 \mathrm{E}+00$ & \\
\hline
\end{tabular}

File:TWR3738Rev1/3738R1DST67

Inhalation Dose-Ratio of SC Release to Wind Entrainment Onsite Receptor, 1 hour

Offsite Receptor, $24 \mathrm{hr}$

1.5


TWR-3738, Rev. 1

67/33 DST Waste $20 \mathrm{gpm}$ Leak

Summary of Results $\quad$ Pipe Length (feet) $\quad 55,000.0$

\begin{tabular}{|c|c|c|c|c|}
\hline Consequences & Receptor & Conseq. & Guideline & Rev 0-B* \\
\hline Radiological & Onsite & $1.70 \mathrm{E}-03$ & $5.00 \mathrm{E}-03$ & $5.10 \mathrm{E}-03$ \\
& Offsite & $6.59 \mathrm{E}-06$ & $1.00 \mathrm{E}-03$ & $6.60 \mathrm{E}-06$ \\
\hline Toxicological & Onsite & $1.98 \mathrm{E}-03$ & $1.00 \mathrm{E}+00$ & $1.40 \mathrm{E}-01$ \\
\hline & Offsite & $8.17 \mathrm{E}-05$ & $1.00 \mathrm{E}+00$ & $7.50 \mathrm{E}-04$ \\
\hline
\end{tabular}

File:TWR3738Rev1/3738R1DST67

\begin{tabular}{|c|c|c|c|c|c|c|c|}
\hline \multicolumn{8}{|c|}{ Radiological Consequences } \\
\hline & \multicolumn{7}{|c|}{ Source Terms by Mechanism(L) } \\
\hline & SupCover & WetResus & Gamma & $\mathrm{X} / \mathrm{Q}(\mathrm{s} / \mathrm{m} 3)$ & $\mathrm{BR}(\mathrm{m} 3 / \mathrm{s})$ & ULD(Sv/L) & Dose(Sv) \\
\hline Inhalation & & $4.92 \mathrm{E}-05$ & & $7.57 \mathrm{E}-04$ & $3.30 \mathrm{E}-04$ & $1.79 \mathrm{E}+05$ & $2.20 \mathrm{E}-06$ \\
\hline & $5.14 E-04$ & & & $3.41 E-02$ & $3.30 \mathrm{E}-04$ & $1.79 E+05$ & $1.04 \mathrm{E}-03$ \\
\hline Gamma" & & & $6.59 E-04$ & & & & $6.59 E-04$ \\
\hline Total & & & & & & & $1.70 \mathrm{E}-03$ \\
\hline Inhalation & & $9.10 \mathrm{E}-02$ & NA & $4.92 E-07$ & $3.30 \mathrm{E}-04$ & $1.79 \mathrm{E}+05$ & $2.64 \mathrm{E}-06$ \\
\hline & $9.39 E-03$ & & NA & $7.07 \mathrm{E}-06$ & $3.30 E-04$ & $1.79 E+05$ & $3.92 \mathrm{E}-06$ \\
\hline Ingestion & & $9.10 E-02$ & & $4.92 \mathrm{E}-07$ & & $2.04 \mathrm{E}-01$ & $9.13 \mathrm{E}-09$ \\
\hline & $9.39 E-03$ & & & 7.07E-06 & & $2.04 \mathrm{E}-01$ & $1.35 \mathrm{E}-08$ \\
\hline Total & & & & & & & $6.59 \mathrm{E}-06$ \\
\hline
\end{tabular}

${ }^{*}$ Gamma $=$ (Shine+Skyshine for Reference Leak) $\times$ (Ratio of Leak Volumes) $\times$ (Ratio of Cs137 Activities)

\begin{tabular}{|l|r|r|r|r|r|r|c|}
\hline Toxicological Consequences & & & & & \\
\hline & Initial Rates (L/s) & $\mathbf{2 4}$ hour Rates (L/s) & & & \\
\hline Location & SupCover & WetResus & SupCover & WetResus & Rate (L/s) & SOF Mult & SOF \\
\hline Onsite & $\mathbf{1 . 4 3 E - 0 7}$ & $1.37 \mathrm{E}-08$ & & & $1.57 \mathrm{E}-07$ & $1.26 \mathrm{E}+04$ & $1.98 \mathrm{E}-03$ \\
\hline & & & & & & & \\
\hline Offsite & $1.43 \mathrm{E}-07$ & $1.37 \mathrm{E}-08$ & $1.43 \mathrm{E}-07$ & $1.05 \mathrm{E}-06$ & $1.20 \mathrm{E}-06$ & $6.83 \mathrm{E}+01$ & $\mathbf{8 . 1 7} \mathrm{E}-05$ \\
\hline
\end{tabular}

File:TWR3738Rev1/3738R1DST67 
TWR-3738, Rev. 1

\section{5/5 DST Waste $20 \mathrm{gpm}$ Leak}

File:TWR3738Rev1/3738R1DST95

DST Radiological Unit Liter Doses

\begin{tabular}{|l|c|c|}
\hline Waste Type & $\begin{array}{c}\text { Inhalation } \\
(\mathrm{Sv} / \mathrm{L})\end{array}$ & $\begin{array}{c}\text { Ingestion } \\
\left(\mathrm{Sv}-\mathrm{m}^{\wedge} 3 / \mathrm{s}\right. \\
\mathrm{L})\end{array}$ \\
\hline DST Liquids & $6.1 \mathrm{E}+03$ & $6.8 \mathrm{E}-02$ \\
DST Solids & $5.3 \mathrm{E}+05$ & $4.8 \mathrm{E}-01$ \\
$95 / 5$ Composite & $3.2 \mathrm{E}+04$ & $8.9 \mathrm{E}-02$ \\
\hline
\end{tabular}

DST Continuous Release SOF Multipliers (s/L)

\begin{tabular}{|l|cc|cc|cc|}
\hline & \multicolumn{2}{|c|}{ Anticipated Frequency } & Unlikely Frequency & \multicolumn{2}{c|}{$\begin{array}{c}\text { Extremely Unlikely } \\
\text { Frequency }\end{array}$} \\
\hline Waste Type & Onsite & Offsite & Onsite & Offsite & Onsite & Offsite \\
\hline DST Liquids & $1.0 \mathrm{E}+04$ & $8.4 \mathrm{E}+00$ & $7.5 \mathrm{E}+02$ & $8.4 \mathrm{E}+00$ & $2.1 \mathrm{E}+02$ & $6.2 \mathrm{E}-01$ \\
DST Solids & $1.8 \mathrm{E}+04$ & $1.9 \mathrm{E}+02$ & $3.3 \mathrm{E}+03$ & $1.5 \mathrm{E}+01$ & $6.3 \mathrm{E}+02$ & $2.8 \mathrm{E}+00$ \\
95/5 Composite & $1.0 \mathrm{E}+04$ & $1.7 \mathrm{E}+01$ & $8.8 \mathrm{E}+02$ & $8.7 \mathrm{E}+00$ & $2.3 \mathrm{E}+02$ & $7.3 \mathrm{E}-01$ \\
\hline
\end{tabular}

Atmospheric Dispersion Coefficients (X/Q)

\begin{tabular}{|l|c|c|}
\hline & Onsite & Offsite \\
\hline $95 \%, 9.8 \mathrm{~m} / \mathrm{s}$, TWR-3958 & $7.57 \mathrm{E}-04$ & $4.92 \mathrm{E}-07$ \\
\hline $99.5 \%, 1 \mathrm{~m} / \mathrm{s}$, TWR-3738 & $3.41 \mathrm{E}-02$ & $7.07 \mathrm{E}-06$ \\
\hline
\end{tabular}

Breathing Rates $(\mathrm{m} 3 / \mathrm{s})$

\begin{tabular}{|l|c|}
\hline light activity & $3.3 \mathrm{E}-04$ \\
\cline { 2 - 2 } 24-hr average & $3.3 \mathrm{E}-04$ \\
\hline
\end{tabular}

Waste Cs-137 Activity (Bq/L)

\begin{tabular}{|l|l|}
\hline Cs-137 Activity for this waste & $5.90 \mathrm{E}+10$ \\
\hline Cs-137 Activity, Ref. DST 95/5 & $5.90 \mathrm{E}+10$ \\
\hline Gamma Multiplier for this waste & $1.00 \mathrm{E}+00$ \\
\hline
\end{tabular}

\begin{tabular}{|c|c|}
\hline Logarithmic Interpolated X/Q & $2.12 E-05$ \\
\hline Time $(\mathrm{hr})=$ & $1.24 \mathrm{E}-07$ \\
\hline$X / Q=707 E 06$ & \\
\hline
\end{tabular}


TWR-3738, Rev. 1

\section{5/5 DST Waste $20 \mathrm{gpm}$ Leak}

Pipe Length (feet) $\quad 75,000.0$

File:TWR3738Rev1/3738R1DST95

Source Term

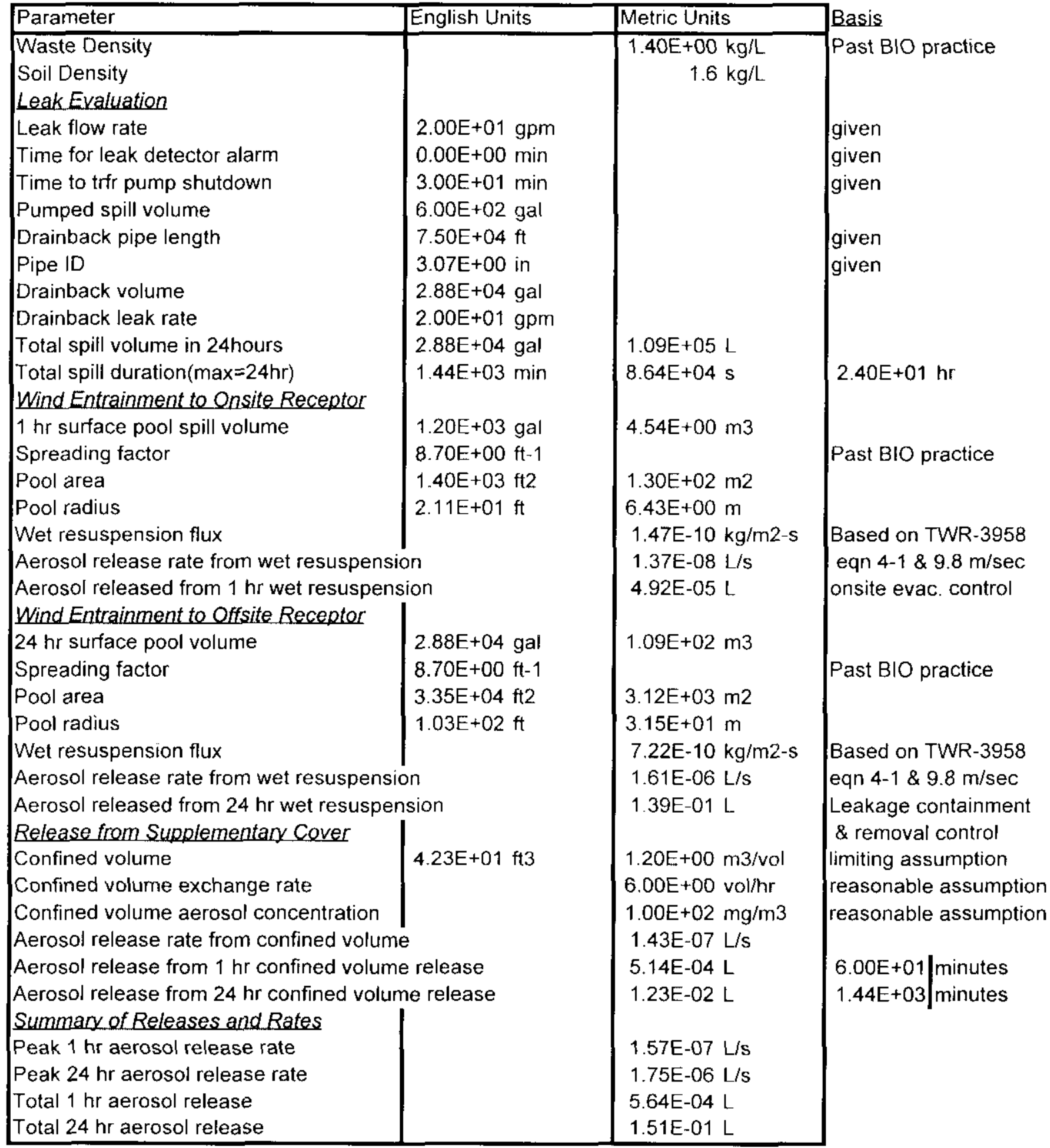


TWR-3738, Rev. 1

\section{5/5 DST Waste 20 gpm Leak}

One hour leak quantity $=$

$1,200 \mathrm{gal}$

$28,800 \mathrm{gal}$

$75,000 \mathrm{ft}$

Line vol. $\begin{array}{ll}\text { Total time } & 240 \mathrm{E}+01 \text { hours } \\ & 1.44 \mathrm{E}+03 \text { minutes }\end{array}$

14.2 miles

28801 gallons

Radiological Consequences

\begin{tabular}{|l|c|c|}
\hline Pathway & Onsite MEl EDE (Sv) & Offsite MEI EDE (Sv) \\
\hline Inhalation & $1.87 \mathrm{E}-04$ & $1.66 \mathrm{E}-06$ \\
Ingestion & NA & $1.38 \mathrm{E}-08$ \\
Gamma-ray & $6.59 \mathrm{E}-04$ & NA \\
Total & $8.46 \mathrm{E}-04$ & $1.67 \mathrm{E}-06$ \\
Anticipated Guideline & $5.00 \mathrm{E}-03$ & $1.00 \mathrm{E}-03$ \\
\hline
\end{tabular}

Toxicological Consequences

\begin{tabular}{|l|c|l|l|l|}
\hline Pathway & Onsite MEI (SOF) & \multicolumn{2}{|l|}{ Offsite MEI (SOF) } \\
\hline Inhalation & $1.63 \mathrm{E}-03$ & & $3.06 \mathrm{E}-05$ & \\
\hline Guideline & $1.00 \mathrm{E}+00$ & & $1.00 \mathrm{E}+00$ & \\
\hline
\end{tabular}

File:TWR3738Rev1/3738R1DST95

Inhalation Dose-Ratio of SC Release to Wind Entrainment

Onsite Receptor, 1 hour

Offsite Receptor, $24 \mathrm{hr}$

470.5

1.3


TWR-3738, Rev. 1

95/5 DST Waste $20 \mathrm{gpm}$ Leak Summary of Results

Pipe Length (feet) $\quad 75,000.0$

\begin{tabular}{|c|c|c|c|c|}
\hline Consequences & Receptor & Conseq. & Guideline & Rev 0-B \\
\hline Radiological & Onsite & $8.46 \mathrm{E}-04$ & $5.00 \mathrm{E}-03$ & $5.10 \mathrm{E}-03$ \\
& Offsite & $1.67 \mathrm{E}-06$ & $1.00 \mathrm{E}-03$ & $6.60 \mathrm{E}-06$ \\
\hline Toxicological & Onsite & $1.63 \mathrm{E}-03$ & $1.00 \mathrm{E}+00$ & $1.40 \mathrm{E}-01$ \\
\hline & Offsite & $3.06 \mathrm{E}-05$ & $1.00 \mathrm{E}+00$ & $7.50 \mathrm{E}-04$ \\
\hline
\end{tabular}

File:TWR3738Rev1/3738R1DST95

\begin{tabular}{|c|c|c|c|c|c|c|c|}
\hline \multicolumn{8}{|c|}{ Radiological Consequences } \\
\hline & \multicolumn{7}{|c|}{ Source Terms by Mechanism(L) } \\
\hline & SupCover & WetResus & Gamma & $\mathrm{X} / \mathrm{Q}(\mathrm{s} / \mathrm{m} 3)$ & $\mathrm{BR}(\mathrm{m} 3 / \mathrm{s})$ & ULD(Sv/L) & Dose(Sv) \\
\hline \multirow[t]{2}{*}{ Onsite } & & $4.92 \mathrm{E}-05$ & & $7.57 E-04$ & $3.30 \mathrm{E}-04$ & $3.23 E+04$ & $3.97 E-07$ \\
\hline & $5.14 \mathrm{E}-04$ & & & $3.41 \mathrm{E}-02$ & $3.30 \mathrm{E}-04$ & $3.23 E+04$ & 1.87E-04 \\
\hline Gamma* & & & $6.59 E-04$ & & & & $6.59 \mathrm{E}-04$ \\
\hline Total & & & & & & & $8.46 \mathrm{E}-04$ \\
\hline \multirow[t]{2}{*}{ Offsite } & & $1.39 \mathrm{E}-01$ & NA & $4.92 \mathrm{E}-07$ & $3.30 \mathrm{E}-04$ & $3.23 \mathrm{E}+04$ & $7.29 E-07$ \\
\hline & $1.23 E-02$ & & NA & $7.07 E-06$ & $3.30 \mathrm{E}-04$ & $3.23 E+04$ & $9.29 E-07$ \\
\hline \multirow[t]{2}{*}{ Ingestion } & & $1.39 \mathrm{E}-01$ & & $4.92 \mathrm{E}-07$ & & $8.86 \mathrm{E}-02$ & $6.06 \bar{E}-09$ \\
\hline & $1.23 E-02$ & & & 7.07E-06 & & $8.86 \mathrm{E}-02$ & $7 . \overline{73 E-09}$ \\
\hline Total & & & & & & & $1.67 E-06$ \\
\hline
\end{tabular}

${ }^{*}$ Gamma $=$ (Shine+Skyshine for Reference Leak) $\times$ (Ratio of Leak Volumes) $\times$ (Ratio of Cs137 Activities)

\begin{tabular}{|l|l|l|l|l|r|c|c|}
\hline Toxicological Consequences & & & & & \\
\hline & Initial Rates (L/s) & 24 hour Rates (L/s) & & & \\
\hline Location & SupCover & WetResus & SupCover & WetResus & Rate (L/s) & SOF Mult & SOF \\
\hline Onsite & $1.43 \mathrm{E}-07$ & $1.37 \mathrm{E}-08$ & & & $1.57 \mathrm{E}-07$ & $1.04 \mathrm{E}+04$ & $1.63 \mathrm{E}-03$ \\
\hline & & & & & & & \\
\hline Offsite & $1.43 \mathrm{E}-07$ & $1.37 \mathrm{E}-08$ & $1.43 \mathrm{E}-07$ & $1.61 \mathrm{E}-06$ & $1.75 \mathrm{E}-06$ & $1.75 \mathrm{E}+01$ & $3.06 \mathrm{E}-05$ \\
\hline
\end{tabular}

File:TWR3738Rev1/3738R1DST95 
TWR-3738, Rev. 1

\section{7/33 SST Waste 20 gpm Leak}

File:TWR3738Rev1/3738R1SST67

SST Radiological Unit Liter Doses

\begin{tabular}{|l|c|c|}
\hline Waste Type & $\begin{array}{c}\text { Inhalation } \\
\text { (Sv/L) }\end{array}$ & $\begin{array}{c}\text { Ingestion } \\
\left(\text { Sv- } \mathrm{m}^{\wedge} 3 / \mathrm{s}\right. \\
\mathrm{L})\end{array}$ \\
\hline SST Liquids & $1.1 \mathrm{E}+04$ & $5.2 \mathrm{E}-02$ \\
SST Solids & $2.2 \mathrm{E}+05$ & $4.1 \mathrm{E}+00$ \\
\hline $67 / 33$ Composite & $8.0 \mathrm{E}+04$ & $1.4 \mathrm{E}+00$ \\
\hline
\end{tabular}

SST Continuous Release SOF Multipliers (s/L)

\begin{tabular}{|c|c|c|c|c|c|c|}
\hline \multirow[b]{2}{*}{ Waste Type } & \multicolumn{2}{|c|}{ Anticipated Frequency } & \multicolumn{2}{|c|}{ Unlikely Frequency } & \multicolumn{2}{|c|}{$\begin{array}{c}\text { Extremely Unlikely } \\
\text { Frequency }\end{array}$} \\
\hline & Onsite & Offsite & Onsite & Offsite & Onsite & Offsite \\
\hline SST Liquids & $9.6 \mathrm{E}+03$ & $8.0 E+00$ & $7.5 \mathrm{E}+02$ & $8.0 E+00$ & $2.0 \mathrm{E}+02$ & $6.2 \mathrm{E}-01$ \\
\hline SST Solids & $4.0 \mathrm{E}+04$ & $9.4 E+01$ & $2.1 E+04$ & $3.3 E+01$ & $1.0 \mathrm{E}+03$ & 1.7E+01 \\
\hline 67/33 Composite & $2.0 \mathrm{E}+04$ & $3.6 \mathrm{E}+01$ & $7.4 \mathrm{E}+03$ & $1.6 \mathrm{E}+01$ & $4.6 E+02$ & $6.2 E+00$ \\
\hline
\end{tabular}

Atmospheric Dispersion Coefficients (X/Q)

\begin{tabular}{|l|c|c|}
\hline & Onsite & Offsite \\
\hline $95 \%, 9.8 \mathrm{~m} / \mathrm{s}$, TWR-3958 & $7.57 \mathrm{E}-04$ & $4.92 \mathrm{E}-07$ \\
\hline $99.5 \%, 1 \mathrm{~m} / \mathrm{s}$, TWR-3738 & $3.41 \mathrm{E}-02$ & $7.07 \mathrm{E}-06$ \\
\hline
\end{tabular}

Breathing Rates ( $\mathrm{m} 3 / \mathrm{s}$ )

\begin{tabular}{|l|c|}
\hline light activity & $3.3 \mathrm{E}-04$ \\
\cline { 2 - 2 } 24-hr average & $3.3 \mathrm{E}-04$ \\
\hline
\end{tabular}

Waste Cs-137 Activity (Bq/L)

\begin{tabular}{|l|l|}
\hline Cs-137 Activity for this waste & $4.77 \mathrm{E}+10$ \\
\hline
\end{tabular} Cs-137 Activity, Ref. DST 95/5 $5.90 \mathrm{E}+10$

\begin{tabular}{ll|l}
\hline Gamma Multiplier for this waste & $8.08 \mathrm{E}-01$
\end{tabular}

Logarithmic Interpolated $X / Q \quad 2.12 \mathrm{E}-05$

Time $(\mathrm{hr})=1.24 \mathrm{E}-07$
$\mathrm{X} / \mathrm{Q}=707 \mathrm{E}-06$ 
TWR-3738, Rev. 1

\section{7/33 SST Waste 20 gpm Leak}

Pipe Length (feet) 75,000.0

File:TWR3738Rev1/3738R1SST67

Source Term

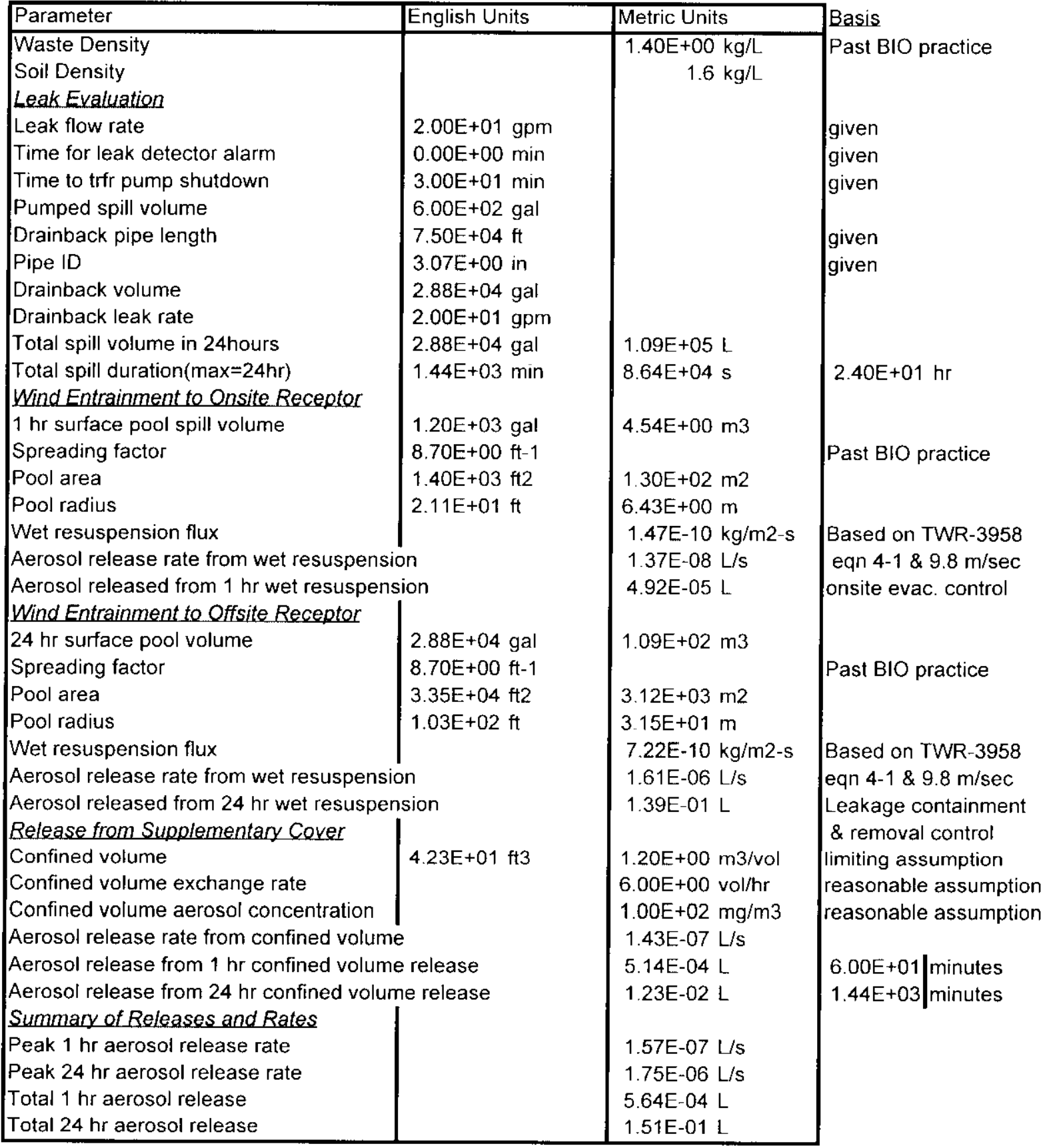


TWR-3738, Rev. 1

\section{7/33 SST Waste $20 \mathrm{gpm}$ Leak}

One hour leak quantity =

24 hour leak quantity $=$

Transfer Line Length =
$1,200 \mathrm{gal}$
$28,800 \mathrm{gal}$
$75,000 \mathrm{ft}$

Line vol.

\section{Total time $2.40 \mathrm{E}+01$ hours \\ $1.44 \mathrm{E}+03$ minutes}

14.2 miles

28801 gallons

Radiological Consequences

\begin{tabular}{|l|c|c|}
\hline Pathway & Onsite MEI EDE (Sv) & Offsite MEI EDE (Sv) \\
\hline Inhalation & $4.64 \mathrm{E}-04$ & $4.11 \mathrm{E}-06$ \\
Ingestion & $\mathrm{NA}$ & $2.16 \mathrm{E}-07$ \\
Gamma-ray & $5.33 \mathrm{E}-04$ & $\mathrm{NA}$ \\
Total & $9.97 \mathrm{E}-04$ & $4.32 \mathrm{E}-06$ \\
Anticipated Guideline & $5.00 \mathrm{E}-03$ & $1.00 \mathrm{E}-03$ \\
\hline
\end{tabular}

Toxicological Consequences

\begin{tabular}{|l|c|l|l|l|}
\hline Pathway & \multicolumn{2}{|l|}{ Onsite MEI (SOF) } & \multicolumn{2}{|c|}{ Offsite MEI (SOF) } \\
\hline Inhalation & $3.07 \mathrm{E}-03$ & & $6.37 \mathrm{E}-05$ & \\
\hline Guideline & $1.00 \mathrm{E}+00$ & & $1.00 \mathrm{E}+00$ & \\
\hline
\end{tabular}

File:TWR3738Rev1/3738R1SST67

\begin{tabular}{|l|r|r|l|}
\hline Inhalation Dose-Ratio of SC Release to Wind Entrainment & \\
\hline Onsite Receptor, 1 hour & 470.5 & & \\
\hline Offsite Receptor, $24 \mathrm{hr}$ & & 1.3 & \\
\hline
\end{tabular}


TWR-3738, Rev. 1

67/33 SST Waste $20 \mathrm{gpm}$ Leak

Summary of Results $\quad$ Pipe Length (feet) $\quad 75,000.0$

\begin{tabular}{|c|c|c|c|c|}
\hline Consequences & Receptor & Conseq. & Guideline & Rev 0-B \\
\hline Radiological & Onsite & $9.97 \mathrm{E}-04$ & $5.00 \mathrm{E}-03$ & $5.10 \mathrm{E}-03$ \\
\hline & Offsite & $4.32 \mathrm{E}-06$ & $1.00 \mathrm{E}-03$ & $6.60 \mathrm{E}-06$ \\
\hline Toxicological & Onsite & $3.07 \mathrm{E}-03$ & $1.00 \mathrm{E}+00$ & $1.40 \mathrm{E}-01$ \\
\hline & Offsite & $6.37 \mathrm{E}-05$ & $1.00 \mathrm{E}+00$ & $7.50 \mathrm{E}-04$ \\
\hline
\end{tabular}

File:TWR3738Rev1/3738R1SST67

\begin{tabular}{|r|r|r|r|r|r|r|r|}
\hline \multicolumn{2}{|l|}{ Radiological Consequences } & & & & & \\
\hline & Source Terms by Mechanism(L) & & & & \\
\hline & SupCover & WetResus & Gamma & X/Q(s/m3) & BR(m3/s) & ULD(Sv/L) & Dose(Sv) \\
\hline Onsite & & $4.92 \mathrm{E}-05$ & & $7.57 \mathrm{E}-04$ & $3.30 \mathrm{E}-04$ & $8.00 \mathrm{E}+04$ & $9.84 \mathrm{E}-07$ \\
\hline & $5.14 \mathrm{E}-04$ & & & $3.41 \mathrm{E}-02$ & $3.30 \mathrm{E}-04$ & $8.00 \mathrm{E}+04$ & $4.63 \mathrm{E}-04$ \\
\hline Gamma* & & & $5.33 \mathrm{E}-04$ & & & & $5.33 \mathrm{E}-04$ \\
\hline Total & & & & & & & $9.97 \mathrm{E}-04$ \\
\hline Offsite & & $1.39 \mathrm{E}-01$ & $\mathrm{NA}$ & $4.92 \mathrm{E}-07$ & $3.30 \mathrm{E}-04$ & $8.00 \mathrm{E}+04$ & $1.80 \mathrm{E}-06$ \\
\hline Inhalation & $1.23 \mathrm{E}-02$ & & $\mathrm{NA}$ & $7.07 \mathrm{E}-06$ & $3.30 \mathrm{E}-04$ & $8.00 \mathrm{E}+04$ & $2.30 \mathrm{E}-06$ \\
\hline & & $1.39 \mathrm{E}-01$ & & $4.92 \mathrm{E}-07$ & & $1.39 \mathrm{E}+00$ & $9.49 \mathrm{E}-08$ \\
\hline & $1.23 \mathrm{E}-02$ & & & $7.07 \mathrm{E}-06$ & & $1.39 \mathrm{E}+00$ & $1.21 \mathrm{E}-07$ \\
\hline
\end{tabular}

${ }^{*}$ Gamma $=($ Shine+Skyshine for Reference Leak $) \times($ Ratio of Leak Volumes) $\times$ (Ratio of Cs137 Activities)

\begin{tabular}{|c|c|c|c|c|c|c|c|}
\hline \multicolumn{8}{|c|}{ Toxicological Consequences } \\
\hline & \multicolumn{2}{|c|}{ Initial Rates (L/s) } & \multicolumn{2}{|c|}{24 hour Rates (L/s) } & & & \\
\hline Location & SupCover & WetResus & SupCover & WetResus & Rate (L/s) & SOF Mult & SOF \\
\hline Onsite & $1.43 \mathrm{E}-07$ & $1.37 E-08$ & & & $1.57 \mathrm{E}-07$ & $1.96 \mathrm{E}+04$ & 3.07E-03 \\
\hline Offsite & $1.43 \mathrm{E}-07$ & $1.37 E-08$ & $1.43 E-07$ & $1.61 \mathrm{E}-06$ & $1.75 \mathrm{E}-06$ & $3.64 \mathrm{E}+01$ & $6.37 \mathrm{E}-05$ \\
\hline
\end{tabular}

File:TWR3738Rev1/3738R1SST67 
TWR-3738, Rev. 1

\section{5/5 SST Waste 20 gpm Leak}

File: TWR3738Rev1/3738R1SST95

SST Radiological Unit Liter Doses

\begin{tabular}{|l|c|c|}
\hline & $\begin{array}{c}\text { Inhalation } \\
\text { Waste Type }\end{array}$ & $\begin{array}{c}\text { Ingestion } \\
(\text { Sv-m^3/s }\end{array}$ \\
\hline SST Liquids & L) \\
SST Solids & $1.1 \mathrm{E}+04$ & $5.2 \mathrm{E}-02$ \\
95/5 Composite & $2.2 \mathrm{E}+05$ & $4.1 \mathrm{E}+00$ \\
\hline
\end{tabular}

SST Continuous Release SOF Multipliers (s/L)

\begin{tabular}{|l|c|c|c|c|c|c|}
\hline \multirow{2}{*}{ Waste Type } & \multicolumn{2}{|c|}{ Anticipated Frequency } & \multicolumn{2}{c|}{ Unlikely Frequency } & \multicolumn{2}{c|}{$\begin{array}{c}\text { Fxtremely Unlikely } \\
\text { Frequency }\end{array}$} \\
\cline { 2 - 7 } & Onsite & Offsite & Onsite & Offsite & Onsite & Offsite \\
\hline SST Liquids & $9.6 \mathrm{E}+03$ & $8.0 \mathrm{E}+00$ & $7.5 \mathrm{E}+02$ & $8.0 \mathrm{E}+00$ & $2.0 \mathrm{E}+02$ & $6.2 \mathrm{E}-01$ \\
SST Solids & $4.0 \mathrm{E}+04$ & $9.4 \mathrm{E}+01$ & $2.1 \mathrm{E}+04$ & $3.3 \mathrm{E}+01$ & $1.0 \mathrm{E}+03$ & $1.7 \mathrm{E}+01$ \\
$95 / 5$ Composite & $1.1 \mathrm{E}+04$ & $1.2 \mathrm{E}+01$ & $1.8 \mathrm{E}+03$ & $9.3 \mathrm{E}+00$ & $2.4 \mathrm{E}+02$ & $1.4 \mathrm{E}+00$ \\
\hline
\end{tabular}

Atmospheric Dispersion Coefficients (X/Q)

\begin{tabular}{|c|c|c|}
\hline & Onsite & Offsite \\
\hline $95 \%, 9.8 \mathrm{~m} / \mathrm{s}$, TWR-3958 & $7.57 \mathrm{E}-04$ & $4.92 \mathrm{E}-07$ \\
\hline $99.5 \%, 1 \mathrm{~m} / \mathrm{s}$, TWR-3738 & $3.41 \mathrm{E}-02$ & $7.07 \mathrm{E}-06$ \\
\hline
\end{tabular}

Breathing Rates (m3/s)

\begin{tabular}{|l|c|}
\hline light activity & $3.3 \mathrm{E}-04$ \\
\hline 24-hr average & $3.3 \mathrm{E}-04$ \\
\hline
\end{tabular}

Waste Cs-137 Activity (Bq/L)

\begin{tabular}{|l|l|}
\hline Cs-137 Activity for this waste & $2.59 \mathrm{E}+10$ \\
\hline Cs-137 Activity
\end{tabular}

\begin{tabular}{|l|l|}
\hline Cs-137 Activity, Ref. DST 95/5 & $5.90 \mathrm{E}+10$ \\
\hline
\end{tabular}

Gamma Multiplier for this waste

4.39E-01

Logarithmic Interpolated X/Q 2.12E-05

Time $(\mathrm{hr})=124 \mathrm{E}-07$

$X / Q=707 \mathrm{E}-06$ 
TWR-3738, Rev. 1

\section{5/5 SST Waste 20 gpm Leak}

Pipe Length (feet) $75,000.0$

File:TWR3738Rev1/3738R1SST95

Source Term

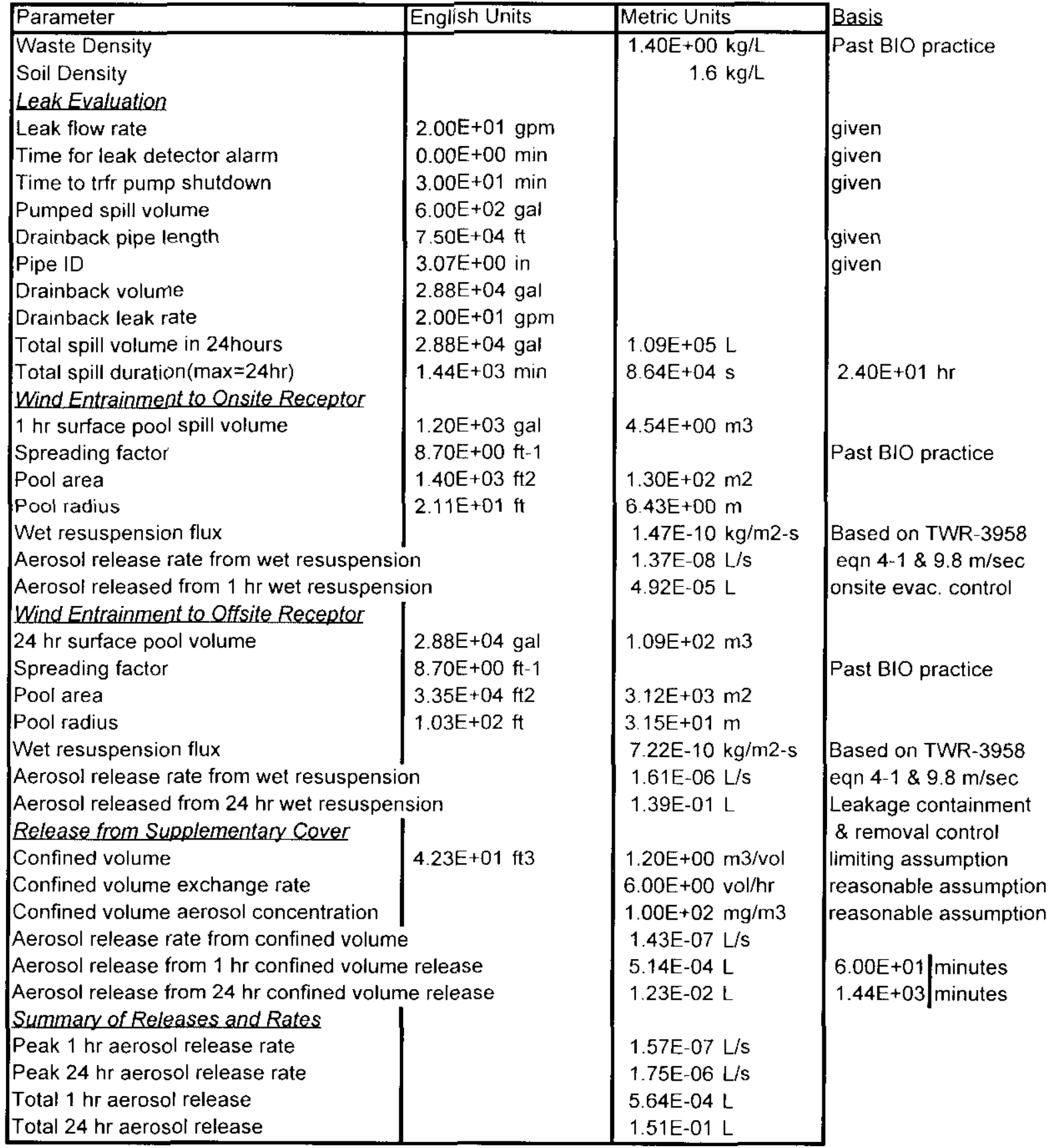


TWR-3738, Rev. 1

95/5 SST Waste 20 gpm Leak

One hour leak quantity =

24 hour leak quantity $=$

Transfer Line Length =
$1,200 \mathrm{gal}$

$28,800 \mathrm{gal}$

$75,000 \mathrm{ft}$

Line vol.

\author{
Total time $2.40 \mathrm{E}+01$ hours \\ $1.44 \mathrm{E}+03$ minutes
}

14.2 miles

28801 gallons

Radiological Consequences

\begin{tabular}{|l|c|c|}
\hline Pathway & Onsite MEI EDE (Sv) & Offsite MEI EDE (Sv) \\
\hline Inhalation & $1.24 \mathrm{E}-04$ & $1.10 \mathrm{E}-06$ \\
Ingestion & $\mathrm{NA}$ & $3.96 \mathrm{E}-08$ \\
Gamma-ray & $2.89 \mathrm{E}-04$ & $\mathrm{NA}$ \\
Total & $4.14 \mathrm{E}-04$ & $1.14 \mathrm{E}-06$ \\
Anticipated Guideline & $5.00 \mathrm{E}-03$ & $1.00 \mathrm{E}-03$ \\
\hline
\end{tabular}

Toxicological Consequences

\begin{tabular}{|c|c|c|}
\hline Pathway & Onsite MEl (SOF) & Offsite MEI (SOF) \\
\hline Inhalation & $1.74 \mathrm{E}-03$ & 2.15E-05 \\
\hline Guideline & $1.00 E+00$ & $1.00 E+00$ \\
\hline
\end{tabular}

File:TWR3738Rev1/3738R1SST95

\begin{tabular}{|c|c|}
\hline Inhalation Dose-Ratic & Entrain \\
\hline Onsite Receptor, 1 hour & 470.5 \\
\hline Offsite Receptor, $24 \mathrm{hr}$ & 1.3 \\
\hline
\end{tabular}


TWR-3738, Rev. 1

$95 / 5$ SST Waste $20 \mathrm{gpm}$ Leak Summary of Results

Pipe Length (feet) $\quad 75,000.0$

\begin{tabular}{|c|c|c|c|c|}
\hline Consequences & Receptor & Conseq. & Guideline & Rev 0-B \\
\hline Radiological & Onsite & $4.14 \mathrm{E}-04$ & $5.00 \mathrm{E}-03$ & $5.10 \mathrm{E}-03$ \\
\hline & Offsite & $1.14 \mathrm{E}-06$ & $1.00 \mathrm{E}-03$ & $6.60 \mathrm{E}-06$ \\
\hline Toxicological & Onsite & $1.74 \mathrm{E}-03$ & $1.00 \mathrm{E}+00$ & $1.40 \mathrm{E}-01$ \\
\hline & Offsite & $2.15 \mathrm{E}-05$ & $1.00 \mathrm{E}+00$ & $7.50 \mathrm{E}-04$ \\
\hline
\end{tabular}

File:TWR3738Rev1/3738R1SST95

\begin{tabular}{|c|c|c|c|c|c|c|c|}
\hline \multicolumn{8}{|c|}{ Radiological Consequences } \\
\hline & \multicolumn{3}{|c|}{ Source Terms by Mechanism(L) } & & & & \\
\hline & SupCover & WetResus & Gamma & $\mathrm{X} / \mathrm{Q}(\mathrm{s} / \mathrm{m} 3)$ & $\mathrm{BR}(\mathrm{m} 3 / \mathrm{s})$ & ULD(Sv/L) & Dose(Sv) \\
\hline Inhalation & & $4.92 \mathrm{E}-05$ & & $7.57 \mathrm{E}-04$ & $3.30 \mathrm{E}-04$ & $2.15 \mathrm{E}+04$ & $2.64 \mathrm{E}-07$ \\
\hline & $5.14 \mathrm{E}-04$ & & & $3.41 \mathrm{E}-02$ & $3.30 \mathrm{E}-04$ & $2.15 E+04$ & $1.24 \mathrm{E}-04$ \\
\hline Gamma* & & & $2.89 \mathrm{E}-04$ & & & & $2.89 \mathrm{E}-04$ \\
\hline Total & & & & & & & $4.14 \mathrm{E}-04$ \\
\hline Inhalation & & 1.39E-01 & NA & $4.92 \mathrm{E}-07$ & $3.30 \mathrm{E}-04$ & $2.15 E+04$ & $4.84 \mathrm{E}-07$ \\
\hline & $1.23 \mathrm{E}-02$ & & NA & 7.07E-06 & $3.30 \mathrm{E}-04$ & $2.15 \mathrm{E}+04$ & $6.17 \mathrm{E}-07$ \\
\hline Ingestion & & $1.39 \mathrm{E}-01$ & & 4.92E-07 & & $2.54 \mathrm{E}-01$ & $1.74 \mathrm{E}-08$ \\
\hline & $1.23 \mathrm{E}-02$ & & & 7.07E-06 & & $2.54 \mathrm{E}-01$ & $2.22 \mathrm{E}-08$ \\
\hline Total & & & & & & & $1.14 \mathrm{E}-06$ \\
\hline
\end{tabular}

${ }^{*}$ Gamma $=($ Shine+Skyshine for Reference Leak)x(Ratio of Leak Volumes) $\times$ (Ratio of Cs 137 Activities)

\begin{tabular}{|l|r|l|l|l|l|l|c|}
\hline Toxicological Consequences & & & & & & \\
\hline & Initial Rates (L/s) & 24 hour Rates (L/s) & & & \\
\hline Location & SupCover & WetResus & SupCover & WetResus & Rate (L/s) & SOF Mult & SOF \\
\hline Onsite & $1.43 \mathrm{E}-07$ & $1.37 \mathrm{E}-08$ & & & $1.57 \mathrm{E}-07$ & $1.11 \mathrm{E}+04$ & $1.74 \mathrm{E}-03$ \\
\hline & & & & & & & \\
\hline Offsite & $1.43 \mathrm{E}-07$ & $1.37 \mathrm{E}-08$ & $1.43 \mathrm{E}-07$ & $1.61 \mathrm{E}-06$ & $1.75 \mathrm{E}-06$ & $1.23 \mathrm{E}+01$ & $2.15 \mathrm{E}-05$ \\
\hline
\end{tabular}

File:TWR3738Rev1/3738R1SST95 
TWR-3738, Rev. 1

\section{7/33 AWF Waste and 20 gpm Leak}

File:TWR3738Rev1/3738R1AWF67

AWF Radiological Unit Liter Doses

\begin{tabular}{|c|c|c|}
\hline Waste Type & $\begin{array}{c}\text { Inhalation } \\
(S \mathrm{~S} / \mathrm{L})\end{array}$ & $\begin{array}{c}\text { Tngestion } \\
\left(\mathrm{Sv}-\mathrm{m}^{\wedge} 3 / \mathrm{s}\right. \\
\mathrm{L})\end{array}$ \\
\hline AWF Liquids & $1.4 \mathrm{E}+03$ & $9.2 \mathrm{E}-02$ \\
\hline AWF Solids & $1.7 E+06$ & $8.1 \mathrm{E}+00$ \\
\hline 67/33 Composite & $5.6 E+05$ & $2.7 E+00$ \\
\hline
\end{tabular}

AWF Continuous Release SOF Multipliers ( $\mathrm{S} / \mathrm{L}$ ) (same as DST)

\begin{tabular}{|l|cc|cc|cc|}
\hline & \multicolumn{2}{|c|}{ Anticipated Frequency } & \multicolumn{2}{|c|}{ Unlikely Frequency } & \multicolumn{2}{c|}{$\begin{array}{c}\text { Fxtremely Unlikely } \\
\text { Waste Type }\end{array}$} \\
\hline Onsite & Offsite & Onsite & Offsite & Onsite & Offsite \\
\hline AWF Liquids & $1.0 \mathrm{E}+04$ & $8.4 \mathrm{E}+00$ & $7.5 \mathrm{E}+02$ & $8.4 \mathrm{E}+00$ & $2.1 \mathrm{E}+02$ & $6.2 \mathrm{E}-01$ \\
AWF Solids & $1.8 \mathrm{E}+04$ & $1.9 \mathrm{E}+02$ & $3.3 \mathrm{E}+03$ & $1.5 \mathrm{E}+01$ & $6.3 \mathrm{E}+02$ & $2.8 \mathrm{E}+00$ \\
$67 / 33$ Composite & $1.3 \mathrm{E}+04$ & $6.8 \mathrm{E}+01$ & $1.6 \mathrm{E}+03$ & $1.1 \mathrm{E}+01$ & $3.5 \mathrm{E}+02$ & $1.3 \mathrm{E}+00$ \\
\hline
\end{tabular}

\section{Atmospheric Dispersion Coefficients (X/Q)}

\begin{tabular}{|c|c|c|}
\hline & Onsite & Offsite \\
\hline $95 \%, 9.8 \mathrm{~m} / \mathrm{s}$, TWR -3958 & $7.57 \mathrm{E}-04$ & $4.92 \mathrm{E}-07$ \\
\hline $99.5 \%, 1 \mathrm{~m} / \mathrm{s}, \mathrm{TWR}-3738$ & $3.41 \mathrm{E}-02$ & $7.07 \mathrm{E}-06$ \\
\hline
\end{tabular}

Breathing Rates (m3/s)

\begin{tabular}{|l|l|}
\hline light activity & $3.3 \mathrm{E}-04$ \\
24-hr average & $3.3 \mathrm{E}-04$ \\
\hline
\end{tabular}

Waste Cs-137 Activity (Bq/L)

\begin{tabular}{|l|l|}
\hline Cs-137 Activity for this waste & $9.13 \mathrm{E}+10$ \\
\hline Cs-137 Activity, Ref. DST 95/5 & $5.90 \mathrm{E}+10$ \\
\hline Gamma Multiplier for this waste & $1.55 \mathrm{E}+00$ \\
\hline
\end{tabular}

Logarithmic Interpolated X/Q

2.12E-05

Time $(h r)=$ 12

$\mathrm{X} / \mathrm{Q}=707 \mathrm{E}-06$ 
TWR-3738, Rev. 1

\section{7/33 AWF Waste and $20 \mathrm{gpm}$ Leak}

Pipe Length (feet)

$75,000.0$

File:TWR3738Rev1/3738R1AWF67

Source Term

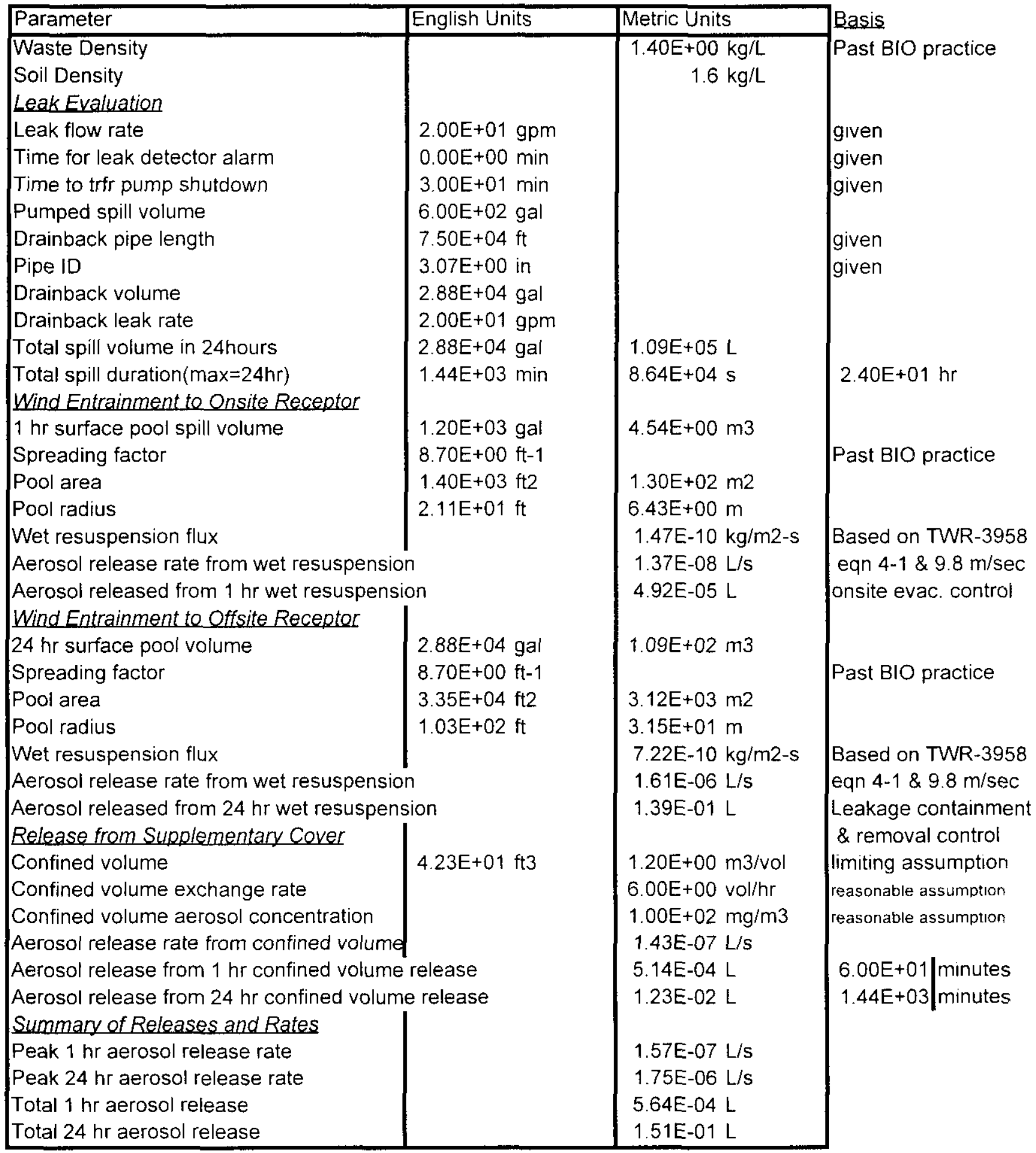


TWR-3738, Rev. 1

\section{7/33 AWF Waste and $20 \mathrm{gpm}$ Leak}

One hour leak quantity $=$

24 hour leak quantity $=$

Transfer Line Length $=$
$1,200 \mathrm{gal}$

$28,800 \mathrm{gal}$

$75,000 \mathrm{ft}$

Line vol.

\section{Total time $2.40 \mathrm{E}+01$ hours \\ $1.44 \mathrm{E}+03$ minutes}

14.2 miles

28801 gallons

Radiological Consequences

\begin{tabular}{|l|c|l|}
\hline Pathway & Onsite MEI EDE (Sv) & Offsite MEl EDE (Sv) \\
\hline Inhalation & $3.26 \mathrm{E}-03$ & $2.88 \mathrm{E}-05$ \\
Ingestion & $\mathrm{NA}$ & $4.25 \mathrm{E}-07$ \\
Gamma-ray & $1.02 \mathrm{E}-03$ & NA \\
Total & $4.28 \mathrm{E}-03$ & $2.93 \mathrm{E}-05$ \\
Anticipated Guideline & $5.00 \mathrm{E}-03$ & $1.00 \mathrm{E}-03$ \\
\hline
\end{tabular}

Toxicological Consequences

\begin{tabular}{|l|c|c|c|c|}
\hline Pathway & Onsite MEI (SOF) & \multicolumn{2}{|l|}{ Offsite MEI (SOF) } \\
\hline Inhalation & $1.98 \mathrm{E}-03$ & & $1.20 \mathrm{E}-04$ & \\
\hline Guideline & $1.00 \mathrm{E}+00$ & & $1.00 \mathrm{E}+00$ & \\
\hline
\end{tabular}

File:TWR3738Rev1/3738R1AWF67 
TWR-3738, Rev. 1

67/33 AWF Waste and $20 \mathrm{gpm}$ Leak

Summary of Results

\begin{tabular}{|c|c|c|c|c|}
\hline Consequences & Receptor & Conseq. & Guideline & Rev 0-B* \\
\hline Radiological & Onsite & $4.3 \mathrm{E}-03$ & $5.0 \mathrm{E}-03$ & $5.1 \mathrm{E}-03$ \\
\hline & Offsite & $2.9 \mathrm{E}-05$ & $1.0 \mathrm{E}-03$ & $6.6 \mathrm{E}-06$ \\
\hline Toxicological & Onsite & $2.0 \mathrm{E}-03$ & $1.0 \mathrm{E}+00$ & $1.4 \mathrm{E}-01$ \\
\hline & Offsite & $1.2 \mathrm{E}-04$ & $1.0 \mathrm{E}+00$ & $7.5 \mathrm{E}-04$ \\
\hline
\end{tabular}

File:TWR3738Rev1/3738R1AWF67

\begin{tabular}{|r|r|r|r|r|r|r|r|}
\hline \multicolumn{2}{|l|}{ Radiological Consequences } & & & & & & \\
\hline & Source Terms by Mechanism(L) & & & & \\
\hline & SupCover & WetResus & Gamma & X/Q(s/m3) & BR(m3/s) & ULD(Sv/L) & Dose(Sv) \\
\hline Onsite & & $4.92 \mathrm{E}-05$ & & $7.57 \mathrm{E}-04$ & $3.30 \mathrm{E}-04$ & $5.62 \mathrm{E}+05$ & $6.91 \mathrm{E}-06$ \\
\hline Inhalation & $5.14 \mathrm{E}-04$ & & & $3.41 \mathrm{E}-02$ & $3.30 \mathrm{E}-04$ & $5.62 \mathrm{E}+05$ & $3.25 \mathrm{E}-03$ \\
\hline Gamma* & & & $1.02 \mathrm{E}-03$ & & & & $1.02 \mathrm{E}-03$ \\
\hline Total & & & & & & & $4.28 \mathrm{E}-03$ \\
\hline Offsite & & $1.39 \mathrm{E}-01$ & NA & $4.92 \mathrm{E}-07$ & $3.30 \mathrm{E}-04$ & $5.62 \mathrm{E}+05$ & $1.27 \mathrm{E}-05$ \\
\hline Inhalation & $1.23 \mathrm{E}-02$ & & NA & $7.07 \mathrm{E}-06$ & $3.30 \mathrm{E}-04$ & $5.62 \mathrm{E}+05$ & $1.62 \mathrm{E}-05$ \\
\hline & & $1.39 \mathrm{E}-01$ & & $4.92 \mathrm{E}-07$ & & $2.73 \mathrm{E}+00$ & $1.87 \mathrm{E}-07$ \\
\hline Ingestion & $1.23 \mathrm{E}-02$ & & & $7.07 \mathrm{E}-06$ & & $2.73 \mathrm{E}+00$ & $2.39 \mathrm{E}-07$ \\
\hline & & & & & & & $2.93 \mathrm{E}-05$ \\
\hline
\end{tabular}

${ }^{*}$ Gamma $=($ Shine+Skyshine for Reference Leak $) \times($ Ratio of Leak Volumes $) \times($ Ratio of Cs137 Activities $)$

\begin{tabular}{|l|l|l|l|l|l|l|c|}
\hline Toxicological Consequences & & & & & \\
\hline \multicolumn{2}{|c|}{ Initial Rates (L/s) } & $\mathbf{2 4}$ hour Rates (L/s) & & & \\
\hline Location & SupCover & WetResus & SupCover & WetResus & Rate (L/s) & SOF Mult & SOF \\
\hline Onsite & $1.43 \mathrm{E}-07$ & $1.37 \mathrm{E}-08$ & & & $1.57 \mathrm{E}-07$ & $1.26 \mathrm{E}+04$ & $1.98 \mathrm{E}-03$ \\
\hline & & & & & & & \\
\hline Offsite & $1.43 \mathrm{E}-07$ & $1.37 \mathrm{E}-08$ & $1.43 \mathrm{E}-07$ & $1.61 \mathrm{E}-06$ & $1.75 \mathrm{E}-06$ & $6.83 \mathrm{E}+01$ & $1.20 \mathrm{E}-04$ \\
\hline
\end{tabular}

File:TWR3738Rev1/3738R1AWF67 
TWR-3738, Rev. 1

\section{7/33 DST Waste $20 \mathrm{gpm}$ Leak}

File:TWR3738Rev1/3738R1DST67

DST Radiological Unit Liter Doses

\begin{tabular}{|l|c|c|}
\hline Waste Type & $\begin{array}{c}\text { Inhalation } \\
(\mathrm{Sv} / \mathrm{L})\end{array}$ & $\begin{array}{c}\text { Ingestion } \\
\left(\mathrm{Sv}-\mathrm{m}^{\wedge} 3 / \mathrm{s}\right. \\
\mathrm{L})\end{array}$ \\
\hline DST Liquids & $6.1 \mathrm{E}+03$ & $6.8 \mathrm{E}-02$ \\
\hline DST Solids & $5.3 \mathrm{E}+05$ & $4.8 \mathrm{E}-01$ \\
\hline 67/33 Composite & $1.8 \mathrm{E}+05$ & $2.0 \mathrm{E}-01$ \\
\hline
\end{tabular}

DST Continuous Release SOF Multipliers ( $\mathrm{S} / \mathrm{L}$ )

\begin{tabular}{|c|c|c|c|c|c|c|}
\hline \multirow[b]{2}{*}{ Waste Type } & \multicolumn{2}{|c|}{ Anticipated Frequency } & \multicolumn{2}{|c|}{ Unlikely Frequency } & \multicolumn{2}{|c|}{$\begin{array}{c}\text { Extremely Unlikely } \\
\text { Frequency }\end{array}$} \\
\hline & Onsite & Offsite & Onsite & Offsite & Onsite & Offsite \\
\hline DST Liquids & $1.0 \mathrm{E}+04$ & $8.4 E+00$ & $7.5 \mathrm{E}+02$ & $8.4 \mathrm{E}+00$ & $2.1 E+02$ & $6.2 \mathrm{E}-01$ \\
\hline DST Solids & $1.8 \mathrm{E}+04$ & $1.9 \mathrm{E}+02$ & $3.3 E+03$ & $1.5 \mathrm{E}+01$ & $6.3 \mathrm{E}+02$ & $2.8 \mathrm{E}+00$ \\
\hline 67/33 Composite & $1.3 E+04$ & $6.8 \mathrm{E}+01$ & $1.6 \mathrm{E}+03$ & 1.1E+01 & $3.5 E+02$ & $1.3 \mathrm{E}+00$ \\
\hline
\end{tabular}

Atmospheric Dispersion Coefficients (X/Q)

\begin{tabular}{|c|c|c|}
\hline & Onsite & Offsite \\
\hline $95 \%, 9.8 \mathrm{~m} / \mathrm{s}$, TWR-3958 & $7.57 \mathrm{E}-04$ & $4.92 \mathrm{E}-07$ \\
\hline $99.5 \%, 1 \mathrm{~m} / \mathrm{s}$, TWR-3738 & $3.41 \mathrm{E}-02$ & $7.07 \mathrm{E}-06$ \\
\hline
\end{tabular}

Breathing Rates $(\mathrm{m} 3 / \mathrm{s})$

\begin{tabular}{|l|l|}
\hline light activity & $3.3 \mathrm{E}-04$ \\
\cline { 2 - 2 } $24-\mathrm{hr}$ average & $3.3 \mathrm{E}-04$ \\
\hline
\end{tabular}

Waste Cs-137 Activity (Bq/L)

\begin{tabular}{|l|l|}
\hline Cs-137 Activity for this waste & $5.90 \mathrm{E}+10$ \\
\hline
\end{tabular}

Cs-137 Activity, Ref. DST 95/5

$5.90 \mathrm{E}+10$

Gamma Multiplier for this waste

$1.00 \mathrm{E}+00$

Logarithmic Interpolated X/Q

2.12E-05

Time $(\mathrm{hr})=$

12

$\mathrm{X} Q=7.07 \mathrm{E}-06$ 
TWR-3738, Rev. 1

\section{7/33 DST Waste 20 gpm Leak \\ $75,000.0$}

Pipe Length (feet)

File:TWR3738Rev1/3738R1DST67

\section{Source Term}

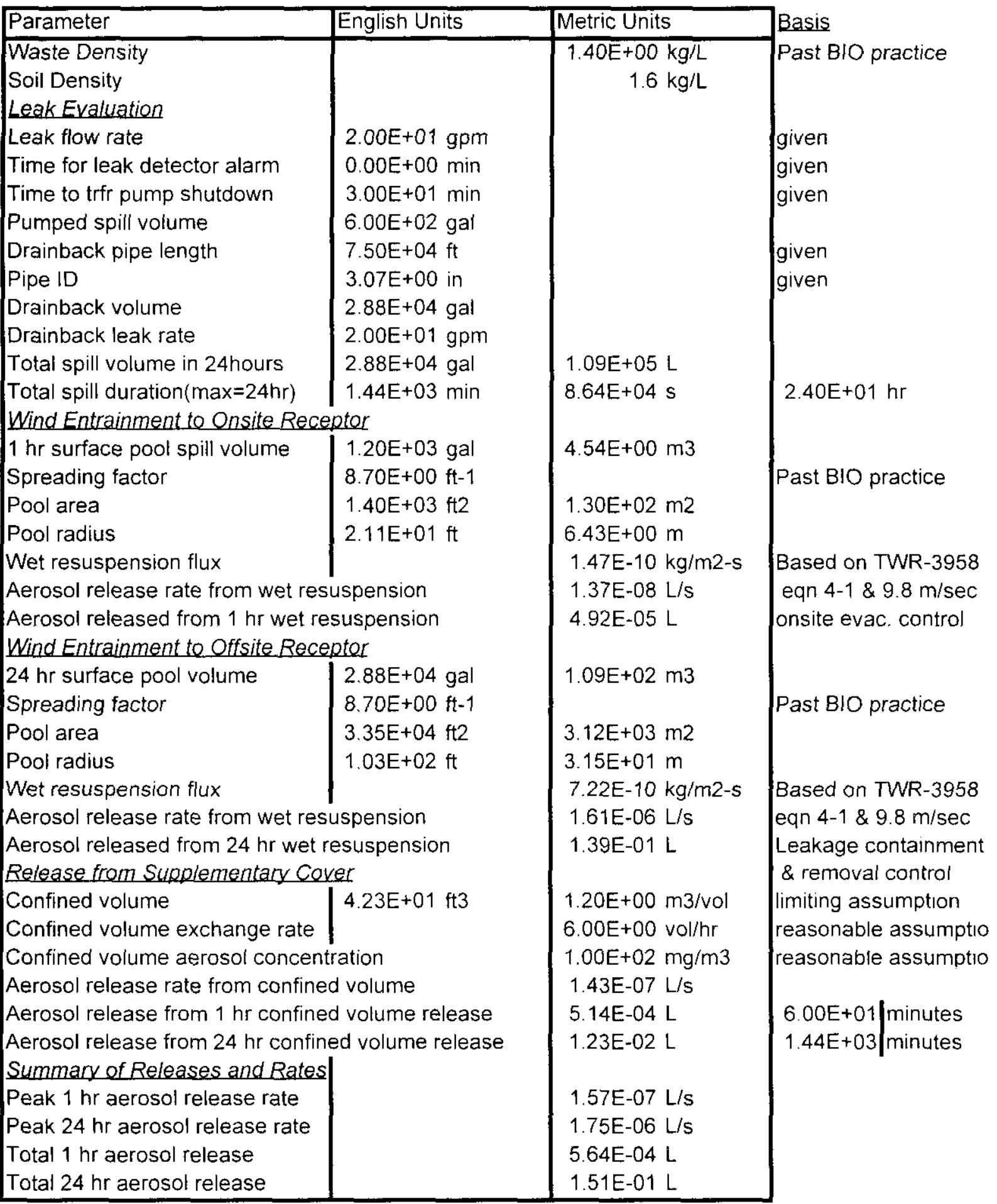


TWR-3738, Rev. 1

\section{7/33 DST Waste $20 \mathrm{gpm}$ Leak}

One hour leak quantity =

24 hour leak quantity $=$

Transfer Line Length =
1,200 gal

$28,800 \mathrm{gal}$

$75,000 \mathrm{ft}$

Line vol $\begin{array}{ll}\text { Total time } & 2.40 \mathrm{E}+01 \text { hours } \\ & 1.44 \mathrm{E}+03 \text { minutes }\end{array}$

14.2 miles

28801 gallons

Radiological Consequences

\begin{tabular}{|l|c|c|}
\hline Pathway & Onsite MEI EDE (Sv) & Offsite MEI EDE (Sv) \\
\hline Inhalation & $1.04 \mathrm{E}-03$ & $9.19 \mathrm{E}-06$ \\
Ingestion & NA & $3.17 \mathrm{E}-08$ \\
Gamma-ray & $6.59 \mathrm{E}-04$ & NA \\
Total & $1.70 \mathrm{E}-03$ & $9.22 \mathrm{E}-06$ \\
Anticipated Guid & $5.00 \mathrm{E}-03$ & $1.00 \mathrm{E}-03$ \\
\hline
\end{tabular}

Toxicological Consequences

\begin{tabular}{|l|c|c|c|c|}
\hline Pathway & \multicolumn{2}{|c|}{ Onsite MEI (SOF) } & \multicolumn{2}{|c|}{ Offsite MEI (SOF) } \\
\hline Inhalation & $1.98 \mathrm{E}-03$ & & $1.20 \mathrm{E}-04$ & \\
\hline Guideline & $1.00 \mathrm{E}+00$ & & $1.00 \mathrm{E}+00$ & \\
\hline
\end{tabular}

File:TWR3738Rev1/3738R1DST67 
TWR-3738, Rev. 1

67/33 DST Waste $20 \mathrm{gpm}$ Leak Summary of Results Pipe Length (feet) $75,000.0$

\begin{tabular}{|c|c|c|c|c|}
\hline Consequences & Receptor & Conseq. & Guideline & Rev 0-B \\
\hline Radiological & Onsite & $1.70 \mathrm{E}-03$ & $5.00 \mathrm{E}-03$ & $5.10 \mathrm{E}-03$ \\
\hline & Offsite & $9.22 \mathrm{E}-06$ & $1.00 \mathrm{E}-03$ & $6.60 \mathrm{E}-06$ \\
\hline Toxicological & Onsite & $1.98 \mathrm{E}-03$ & $1.00 \mathrm{E}+00$ & $1.40 \mathrm{E}-01$ \\
\hline & Offsite & $1.20 \mathrm{E}-04$ & $1.00 \mathrm{E}+00$ & $7.50 \mathrm{E}-04$ \\
\hline
\end{tabular}

File:TWR3738Rev1/3738R1DST67

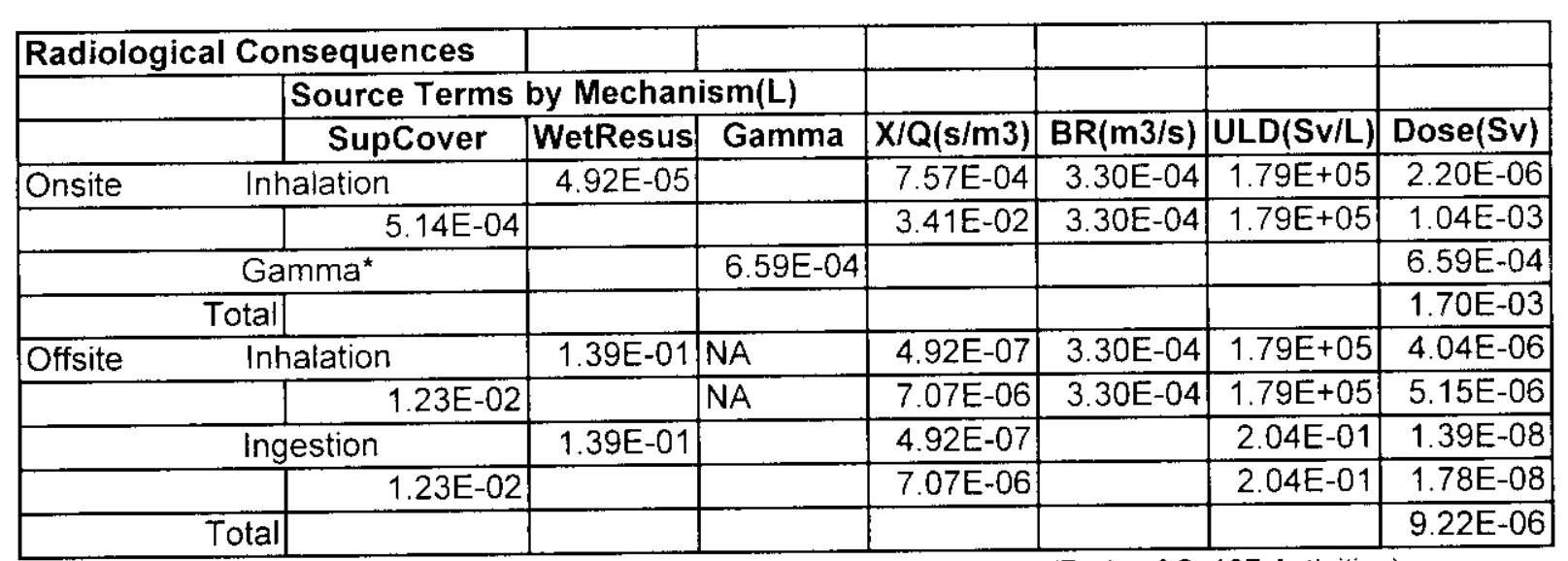

*Gamma = (Shine+Skyshine for Reference Leak)x(Ratio of Leak Volumes)x(Ratio of Cs137 Activities)

\begin{tabular}{|l|c|c|c|c|c|c|c|}
\hline Toxicological Consequences & & & & & \\
\hline & Initial Rates (L/s) & $\mathbf{2 4}$ hour Rates (L/s) & & & \\
\hline Location & SupCover & WetResus & SupCover & WetResus & Rate (L/s) & SOF Mult & SOF \\
\hline Onsite & $1.43 \mathrm{E}-07$ & $1.37 \mathrm{E}-08$ & & & $1.57 \mathrm{E}-07$ & $1.26 \mathrm{E}+04$ & $1.98 \mathrm{E}-03$ \\
\hline & & & & & & & \\
\hline Offsite & $1.43 \mathrm{E}-07$ & $1.37 \mathrm{E}-08$ & $1.43 \mathrm{E}-07$ & $1.61 \mathrm{E}-06$ & $1.75 \mathrm{E}-06$ & $6.83 \mathrm{E}+01$ & $1.20 \mathrm{E}-04$ \\
\hline
\end{tabular}

File:TWR3738Rev1/3738R1DST67 
TWR-3738, Rev. 1

\section{7/33 AWF Waste/20 gpm Leak for Limiting Pit Size-HNF5147}

File:TWR3738Rev1/PIT3738R1C

Radiological Unit Liter Doses

\begin{tabular}{|l|c|c|}
\hline Waste Type & $\begin{array}{c}\text { Inhalation } \\
(\mathrm{S} v / \mathrm{L})\end{array}$ & $\begin{array}{c}\text { (Sv-m^3/s- } \\
\mathrm{L})\end{array}$ \\
\hline AWF Liquids & $1.400 \mathrm{E}+03$ & $9.200 \mathrm{E}-02$ \\
AWF Solids & $1.700 \mathrm{E}+06$ & $8.100 \mathrm{E}+00$ \\
$67 / 33$ Composite & $5.619 \mathrm{E}+05$ & $2.735 \mathrm{E}+00$ \\
\hline
\end{tabular}

Continuous Release SOF Multipliers ( $/ \mathrm{L}$ )

\begin{tabular}{|l|c|c|c|c|c|c|}
\hline \multirow{2}{*}{ Waste Type } & \multicolumn{2}{|c|}{ Anticipated Frequency } & \multicolumn{2}{|c|}{ Unlikely Frequency } & \multicolumn{2}{c|}{$\begin{array}{c}\text { Fxtremely Unlikely } \\
\text { Frequency }\end{array}$} \\
\cline { 2 - 8 } & Onsite & Offsite & Onsite & Offsite & Onsite & Offsite \\
\hline AWF Liquids & $1.000 \mathrm{E}+04$ & $8.400 \mathrm{E}+00$ & $7.5 \mathrm{E}+02$ & $8.4 \mathrm{E}+00$ & $2.1 \mathrm{E}+02$ & $6.2 \mathrm{E}-01$ \\
AWF Solids & $1.800 \mathrm{E}+04$ & $1.900 \mathrm{E}+02$ & $3.3 \mathrm{E}+03$ & $1.5 \mathrm{E}+01$ & $6.3 \mathrm{E}+02$ & $2.8 \mathrm{E}+00$ \\
$67 / 33$ Composite & $1.264 \mathrm{E}+04$ & $6.833 \mathrm{E}+01$ & $1.6 \mathrm{E}+03$ & $1.1 \mathrm{E}+01$ & $3.5 \mathrm{E}+02$ & $1.3 \mathrm{E}+00$ \\
\hline
\end{tabular}

Atmospheric Dispersion Coefficients (X/Q)

\begin{tabular}{|c|c|c|}
\hline & Onsite & Offsite \\
\hline $95 \%, 9.8 \mathrm{~m} / \mathrm{s}$, TWR -3958 & $7.57 \mathrm{E}-04$ & $4.92 \mathrm{E}-07$ \\
\hline $99.5 \%, 1 \mathrm{~m} / \mathrm{s}$, TWR-3738 & $3.41 \mathrm{E}-02$ & $283 \mathrm{E}-05$ \\
\hline
\end{tabular}

Breathing Rates (m3/s)

\begin{tabular}{|l|l|}
\hline light activity & $3.3 \mathrm{E}-04$ \\
\hline 24-hr average & $3.3 \mathrm{E}-04$ \\
\hline
\end{tabular}

Waste Cs-137 Activity (Bq/L)

Cs-137 Activity for this waste Cs-137 Activity, Ref. DST 95/5 9.13E+10 $5.90 \mathrm{E}+10$ Gamma Multiplier for this waste 
67/33 AWF Waste/20 gpm Leak for Limiting Pit Size-HNF5147

Pipe Length (feet)

File:TWR3738Rev1/PIT3738R1C

\begin{tabular}{|c|c|c|}
\hline $\begin{array}{l}\text { Source Term } \\
\text { Parameter }\end{array}$ & English Units & Metric Units \\
\hline Waste Density & & $1.40 \mathrm{E}+00 \mathrm{~kg} / \mathrm{L}$ \\
\hline Soil Density & & $1.6 \mathrm{~kg} / \mathrm{L}$ \\
\hline Leak Evaluation & & \\
\hline Leak flow rate & $2.00 \mathrm{E}+01 \mathrm{gpm}$ & 7.57E+01 L/min \\
\hline Time for leak detector alarm & $3.00 \mathrm{E}+01 \mathrm{~min}$ & \\
\hline Time to trfr pump shutdown & $3.00 \mathrm{E}+01 \mathrm{~min}$ & \\
\hline Pumped spill volume & $1.20 \mathrm{E}+03 \mathrm{gal}$ & $4.54 \mathrm{E}+03 \mathrm{~L}$ \\
\hline Drainback pipe length & $0.00 \mathrm{E}+00 \mathrm{ft}$ & \\
\hline Pipe ID & $3.07 E+00$ in & \\
\hline Drainback volume & $0.00 \mathrm{E}+00 \mathrm{gal}$ & \\
\hline Drainback leak rate & $2.00 \mathrm{E}+01 \mathrm{gpm}$ & 7.57E+01 L/min \\
\hline Total spill volume in 24 hours & $1.20 \mathrm{E}+03 \mathrm{gal}$ & $4.54 E+03 L$ \\
\hline Total spill duration $(\max =24 \mathrm{hr}$ ) & $6.00 \mathrm{E}+01 \mathrm{~min}$ & $3.60 \mathrm{E}+03 \mathrm{~s}$ \\
\hline NO Wind Entrainment to Onsit & ator & \\
\hline $1 \mathrm{hr}$ surface pool spill volume & $0.00 \mathrm{E}+00 \mathrm{gal}$ & $0.00 \mathrm{E}+00 \mathrm{~m} 3$ \\
\hline Spreading factor & $8.70 \mathrm{E}+00 \mathrm{ft}-1$ & \\
\hline Pool area & $0.00 \mathrm{E}+00 \mathrm{ft} 2$ & $0.00 \mathrm{E}+00 \mathrm{~m} 2$ \\
\hline Pool radius & $0.00 \mathrm{E}+00 \mathrm{ft}$ & $0.00 \mathrm{E}+00 \mathrm{~m}$ \\
\hline Wet resuspension flux & & $0.00 \mathrm{E}+00 \mathrm{~kg} / \mathrm{m} 2-\mathrm{s}$ \\
\hline Aerosol release rate from wet & nsion & $0.00 \mathrm{E}+00 \mathrm{~L} / \mathrm{s}$ \\
\hline Aerosol released from $1 \mathrm{hr}$ we & ension & $0.00 \mathrm{E}+00 \mathrm{~L}$ \\
\hline NO Wind Entrainment to Offsit & otor & \\
\hline $24 \mathrm{hr}$ surface pool volume & $0.00 \mathrm{E}+00 \mathrm{gal}$ & $0.00 \mathrm{E}+00 \mathrm{~m} 3$ \\
\hline Spreading factor & $8.70 \mathrm{E}+00 \mathrm{ft}-1$ & \\
\hline Pool area & $0.00 \mathrm{E}+00 \mathrm{ft} 2$ & $0.00 \mathrm{E}+00 \mathrm{~m} 2$ \\
\hline Pool radius & $0.00 \mathrm{E}+00 \mathrm{ft}$ & $0.00 \mathrm{E}+00 \mathrm{~m}$ \\
\hline Wet resuspension flux & & $0.00 \mathrm{E}+00 \mathrm{~kg} / \mathrm{m} 2-\mathrm{s}$ \\
\hline Aerosol release rate from wet $\mathrm{r}$ & nsion & $0.00 \mathrm{E}+00 \mathrm{~L} / \mathrm{s}$ \\
\hline Aerosol released from $24 \mathrm{hr}$ we & pension & $0.00 E+00 \mathrm{~L}$ \\
\hline Pit internal volume & $3.20 \mathrm{E}+03 \mathrm{ft} 3$ & $9.06 \mathrm{E}+01 \mathrm{~m} 3$ \\
\hline Confined volume aerosol conc & & 7.14E-05 L/m3 \\
\hline Confined volume aerosol conc & & $1.00 \mathrm{E}-01 \mathrm{~g} / \mathrm{m} 3$ \\
\hline Aerosol release rate from conf & ume & 1.80E-06 L/s \\
\hline Onsite aerosol release from pit & & $6.47 \mathrm{E}-03 \mathrm{~L}$ \\
\hline Pit aerosol release in $24 \mathrm{hr}$ & & $6.47 \mathrm{E}-03 \mathrm{~L}$ \\
\hline Summary of Releases and Rat & & \\
\hline Peak Onsite aerosol release ra & pit & 1.80E-06 L/s \\
\hline Peak $24 \mathrm{hr}$ release rate (pit) & & 1.80E-06 L/s \\
\hline Total Onsite aerosol release & & 6.47E-03 L \\
\hline Total $24 \mathrm{hr}$ aerosol release & & 6.47E-03 L \\
\hline
\end{tabular}

Basis

Past $\mathrm{BIO}$ practice

given

Input parameter

given

$4.54 \mathrm{E}+00 \mathrm{~m} 3$

given

given

$4.54 \mathrm{E}+00 \mathrm{~m} 3$

$1.00 \mathrm{E}+00 \mathrm{hr}$

Past $\mathrm{BIO}$ practice

Based on TWR-3958

eqn 4-1 \& $9.8 \mathrm{~m} / \mathrm{sec}$

onsite evac. control

Past BIO practice

Based on TWR-3958

eqn $4-1 \& 9.8 \mathrm{~m} / \mathrm{sec}$

Leakage containment

\& removal control

nput parameter

Quası-equilibrium Concen-

tration(PNL-4154)

$6.00 E+01$ minutes

1.44E+03 minutes 
TWR-3738, Rev. 1

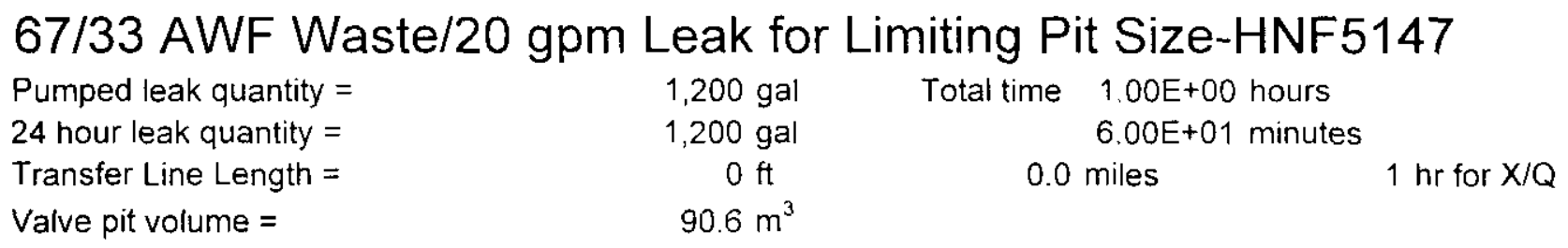

Radiological Consequences

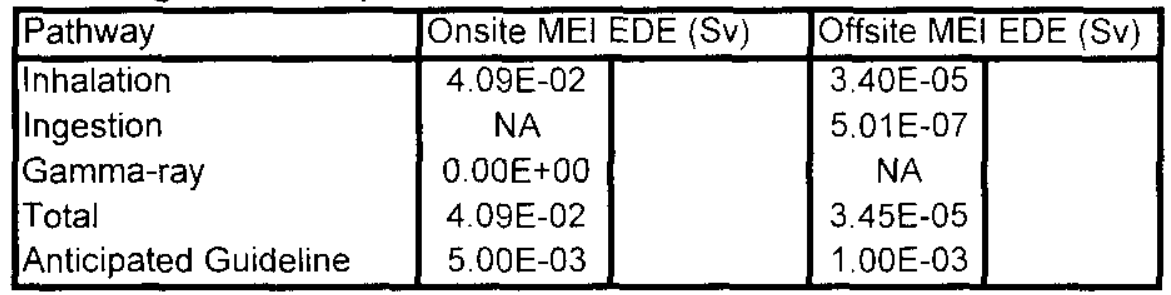

\section{Toxicological Consequences}

\begin{tabular}{|l|c|l|l|l|}
\hline Pathway & \multicolumn{2}{|c|}{ Onsite MEl (SOF) } & \multicolumn{2}{|c|}{ Offsite MEI (SOF) } \\
\hline Inhalation & $2.27 \mathrm{E}-02$ & & $1.23 \mathrm{E}-04$ & \\
\hline Guideline & $1.00 \mathrm{E}+00$ & & $1.00 \mathrm{E}+00$ & \\
\hline
\end{tabular}

File:TWR3738Rev1/PIT3738R1C 
TWR-3738, Rev. 1

67/33 AWF Waste/20 gpm Leak for Limiting Pit Size-HNF5147

Summary of Results

Pit Volume ( $\mathrm{ft} 3$ )

$\mathrm{m}^{3}$
$3.20 \mathrm{E}+03$

90.6

\begin{tabular}{|c|c|c|c|c|c|}
\hline Consequences & Receptor & Conseq. & Guideline & Rev 0-B* & HNF-5147 \\
\hline Radiological & Onsite & $4.1 \mathrm{E}-02$ & $5.0 \mathrm{E}-03$ & $5.1 \mathrm{E}-03$ & $4.1 \mathrm{E}-02$ \\
\hline & Offsite & $3.4 \mathrm{E}-05$ & $1.0 \mathrm{E}-03$ & $6.6 \mathrm{E}-06$ & $3.7 \mathrm{E}-05$ \\
\hline Toxicological & Onsite & $2.3 \mathrm{E}-02$ & $1.0 \mathrm{E}+00$ & $1.4 \mathrm{E}-01$ & \multicolumn{1}{|c}{} \\
\hline & Offsite & $1.2 \mathrm{E}-04$ & $1.0 \mathrm{E}+00$ & $7.5 \mathrm{E}-04$ \\
\cline { 1 - 3 }
\end{tabular}

File:TWR3738Rev1/PIT3738R1C

\begin{tabular}{|r|r|r|r|r|r|r|r|}
\hline Radiological Consequences & & & & & & \\
\hline & Source Terms by Mechanism(L) & & & & \\
\hline & Pit & WetResus & Gamma & X/Q(s/m3) & $\mathbf{B R}(\mathbf{m} 3 / \mathbf{s})$ & ULD(Sv/L) & Dose(Sv) \\
\hline Onsite Inhalation & & $0.00 \mathrm{E}+00$ & & $7.57 \mathrm{E}-04$ & $3.30 \mathrm{E}-04$ & $5.62 \mathrm{E}+05$ & $0.00 \mathrm{E}+00$ \\
\hline & $6.47 \mathrm{E}-03$ & & & $3.41 \mathrm{E}-02$ & $3.30 \mathrm{E}-04$ & $5.62 \mathrm{E}+05$ & $4.09 \mathrm{E}-02$ \\
\hline Gamma & & & $0.00 \mathrm{E}+00$ & & & & $0.00 \mathrm{E}+00$ \\
\hline Onsite Total & & & & & & & $4.09 \mathrm{E}-02$ \\
\hline Offsite Inhalation & & $0.00 \mathrm{E}+00$ & NA & $4.92 \mathrm{E}-07$ & $3.30 \mathrm{E}-04$ & $5.62 \mathrm{E}+05$ & $0.00 \mathrm{E}+00$ \\
\hline & $6.47 \mathrm{E}-03$ & & NA & $2.83 \mathrm{E}-05$ & $3.30 \mathrm{E}-04$ & $5.62 \mathrm{E}+05$ & $3.40 \mathrm{E}-05$ \\
\hline Ingestion & & $0.00 \mathrm{E}+00$ & & $4.92 \mathrm{E}-07$ & & $2.73 \mathrm{E}+00$ & $0.00 \mathrm{E}+00$ \\
\hline & $6.47 \mathrm{E}-03$ & & & $2.83 \mathrm{E}-05$ & & $2.73 \mathrm{E}+00$ & $5.01 \mathrm{E}-07$ \\
\hline Offsite Total & & & & & & & $3.45 \mathrm{E}-05$ \\
\hline
\end{tabular}

${ }^{*}$ Gamma $=($ Shine+Skyshine for Reference Leak) $\times($ Ratio of Leak Volumes) $x$ (Ratio of Cs137 Activities)

\begin{tabular}{|c|c|c|c|c|c|c|c|}
\hline \multicolumn{2}{|l|}{ Toxicological Consequences } & & & & & & \\
\hline & Initial Rates (L/s) & 24 hour Rates (L/s) & & & \\
\hline Location & Pit & WetResus & Pit & WetResus & Rate (L/s) & SOF Mult & SOF \\
\hline Onsite & $1.80 \mathrm{E}-06$ & $0.00 \mathrm{E}+00$ & & & $1.80 \mathrm{E}-06$ & $1.26 \mathrm{E}+04$ & $2.27 \mathrm{E}-02$ \\
\hline & & & & & & & \\
\hline Offsite & $1.80 \mathrm{E}-06$ & $0.00 \mathrm{E}+00$ & $1.80 \mathrm{E}-06$ & $0.00 \mathrm{E}+00$ & $1.80 \mathrm{E}-06$ & $6.83 \mathrm{E}+01$ & $1.23 \mathrm{E}-04$ \\
\hline
\end{tabular}

File:TWR3738Rev1/PIT3738R1C 


\section{5/5 AWF Waste/20 gpm Leak for Limiting Pit Size-HNF5147}

File:TWR3738Rev1/PIT3738R1C

Radiological Unit Liter Doses

\begin{tabular}{|l|c|c|}
\hline Waste Type & $\begin{array}{c}\text { Ingestion } \\
(S v / L)\end{array}$ & $\begin{array}{c}\text { In }) \\
\left(S v-m^{\wedge} 3 / \mathrm{s}-\right.\end{array}$ \\
\hline AWF Liquids & $1.400 \mathrm{E}+03$ & $9.200 \mathrm{E}-02$ \\
AWF Solids & $1.700 \mathrm{E}+06$ & $8.100 \mathrm{E}+00$ \\
$95 / 5$ Composite & $8.633 \mathrm{E}+04$ & $4.924 \mathrm{E}-01$ \\
\hline
\end{tabular}

Continuous Release SOF Multipliers (S/L)

\begin{tabular}{|l|c|c|c|c|c|c|}
\hline \multirow{2}{*}{ Waste Type } & \multicolumn{2}{|c|}{ Anticipated Frequency } & Unlikely Frequency & \multicolumn{2}{c|}{$\begin{array}{c}\text { Extremely Unlikely } \\
\text { Frequency }\end{array}$} \\
\cline { 2 - 7 } & Onsite & Offsite & Onsite & Offsite & Onsite & Offsite \\
AWF Liquids & $1.000 \mathrm{E}+04$ & $8.400 \mathrm{E}+00$ & $7.5 \mathrm{E}+02$ & $8.4 \mathrm{E}+00$ & $2.1 \mathrm{E}+02$ & $6.2 \mathrm{E}-01$ \\
AWF Solids & $1.800 \mathrm{E}+04$ & $1.900 \mathrm{E}+02$ & $3.3 \mathrm{E}+03$ & $1.5 \mathrm{E}+01$ & $6.3 \mathrm{E}+02$ & $2.8 \mathrm{E}+00$ \\
$95 / 5$ Composite & $1.040 \mathrm{E}+04$ & $1.748 \mathrm{E}+01$ & $8.8 \mathrm{E}+02$ & $8.7 \mathrm{E}+00$ & $2.3 \mathrm{E}+02$ & $7.3 \mathrm{E}-01$ \\
\hline
\end{tabular}

Atmospheric Dispersion Coefficients (X/Q)

\begin{tabular}{|l|c|c|}
\hline & Onsite & Offsite \\
\hline $95 \%, 9.8 \mathrm{~m} / \mathrm{s}$, TWR -3958 & $7.57 \mathrm{E}-04$ & $4.92 \mathrm{E}-07$ \\
\hline $99.5 \%, 1 \mathrm{~m} / \mathrm{s}$, TWR-3738 & $3.41 \mathrm{E}-02$ & $2.83 \mathrm{E}-05$ \\
\hline
\end{tabular}

Breathing Rates $(\mathrm{m} 3 / \mathrm{s})$

\begin{tabular}{|l|r|}
\hline light activity & $3.3 \mathrm{E}-04$ \\
\hline $24-\mathrm{hr}$ average & $3.3 \mathrm{E}-04$ \\
\hline
\end{tabular}

Waste Cs-137 Activity (Bq/L)

\begin{tabular}{|l|l|}
\hline Cs-137 Activity for this waste & $8.85 \mathrm{E}+10$ \\
\hline Cs-137 Activity, Ref. DST 95/5 & $5.90 \mathrm{E}+10$ \\
\hline Gamma Multiplier for this waste & $1.50 \mathrm{E}+00$ \\
\hline
\end{tabular}


TWR-3738, Rev. 1

\section{5/5 AWF Waste/20 gpm Leak for Limiting Pit Size-HNF5147}

Pipe Length (feet)

0.0

Pit Vol.

$1.39 E+04$ feet $^{3}$

File:TWR3738Rev1/PIT3738R1C

\begin{tabular}{|c|c|c|c|}
\hline $\begin{array}{l}\text { Source Term } \\
\text { Parameter }\end{array}$ & English Units & Metric Units & Basis \\
\hline $\begin{array}{l}\text { Waste Density } \\
\text { Soil Density } \\
\text { Leak Evaluation }\end{array}$ & & $\begin{array}{r}1.40 \mathrm{E}+00 \mathrm{~kg} / \mathrm{L} \\
1.6 \mathrm{~kg} / \mathrm{L}\end{array}$ & Past BIO practice \\
\hline Leak flow rate & $2.00 \mathrm{E}+01 \mathrm{gpm}$ & 7.57E+01 L/min & given \\
\hline Time for leak detector alarm & $3.00 \mathrm{E}+01 \mathrm{~min}$ & & Input parameter \\
\hline Time to trfr pump shutdown & $3.00 \mathrm{E}+01 \mathrm{~min}$ & & given \\
\hline Pumped spill volume & $1.20 \mathrm{E}+03 \mathrm{gal}$ & 4.54E+03 L & $4.54 \mathrm{E}+00 \mathrm{~m} 3$ \\
\hline Drainback pipe length & $0.00 \mathrm{E}+00 \mathrm{ft}$ & & given \\
\hline $\begin{array}{l}\text { Pipe ID } \\
\text { Drainback volume }\end{array}$ & $\begin{array}{l}3.07 \mathrm{E}+00 \mathrm{in} \\
0.00 \mathrm{E}+00 \mathrm{gal}\end{array}$ & & given \\
\hline Drainback leak rate & $2.00 \mathrm{E}+01 \mathrm{gpm}$ & 7.57E+01 L/min & \\
\hline Total spill volume in 24 hours & $1.20 \mathrm{E}+03 \mathrm{gal}$ & 4.54E+03 L & $4.54 \mathrm{E}+00 \mathrm{~m} 3$ \\
\hline Total spill duration $(\max =24 \mathrm{hr})$ & $6.00 E+01 \mathrm{~min}$ & $3.60 \mathrm{E}+03 \mathrm{~s}$ & $1.00 \mathrm{E}+00 \mathrm{hr}$ \\
\hline NO Wind Entrainment to Onsite & otor & & \\
\hline $1 \mathrm{hr}$ surface pool spill volume & $0.00 \mathrm{E}+00 \mathrm{gal}$ & $0.00 \mathrm{E}+00 \mathrm{~m} 3$ & \\
\hline Spreading factor & $8.70 \mathrm{E}+00 \mathrm{ft}-1$ & & Past BIO practice \\
\hline Pool area & $0.00 \mathrm{E}+00 \mathrm{ft} 2$ & $0.00 \mathrm{E}+00 \mathrm{~m} 2$ & \\
\hline Pool radius & $0.00 \mathrm{E}+00 \mathrm{ft}$ & $0.00 \mathrm{E}+00 \mathrm{~m}$ & \\
\hline Wet resuspension flux & & $0.00 \mathrm{E}+00 \mathrm{~kg} / \mathrm{m} 2-\mathrm{s}$ & Based on TWR-3958 \\
\hline Aerosol release rate from wet $r$ & nsion & $0.00 \mathrm{E}+00 \mathrm{~L} / \mathrm{s}$ & eqn $4-1 \& 9.8 \mathrm{~m} / \mathrm{sec}$ \\
\hline $\begin{array}{l}\text { Aerosol released from } 1 \mathrm{hr} \text { wet } \\
\text { NO Wind Entrainment to Offsite }\end{array}$ & $\begin{array}{l}\text { ension } \\
\text { tor }\end{array}$ & $0.00 \mathrm{E}+00 \mathrm{~L}$ & onsite evac. control \\
\hline $24 \mathrm{hr}$ surface pool volume & $0.00 \mathrm{E}+00 \mathrm{gal}$ & $0.00 \mathrm{E}+00 \mathrm{~m} 3$ & \\
\hline Spreading factor & $8.70 \mathrm{E}+00 \mathrm{ft}-1$ & & Past BIO practice \\
\hline Pool area & $0.00 \mathrm{E}+00 \mathrm{ft} 2$ & $0.00 \mathrm{E}+00 \mathrm{~m} 2$ & \\
\hline Pool radius & $0.00 \mathrm{E}+00 \mathrm{ft}$ & $0.00 \mathrm{E}+00 \mathrm{~m}$ & \\
\hline Wet resuspension flux & & $0.00 \mathrm{E}+00 \mathrm{~kg} / \mathrm{m} 2-\mathrm{s}$ & Based on TWR-3958 \\
\hline Aerosol release rate from wet $r$ & sion & $0.00 \mathrm{E}+00 \mathrm{~L} / \mathrm{s}$ & eqn $4-1 \& 9.8 \mathrm{~m} / \mathrm{sec}$ \\
\hline $\begin{array}{l}\text { Aerosol released from } 24 \mathrm{hr} \text { we } \\
\text { Release from Pit }\end{array}$ & pension & $0.00 \mathrm{E}+00 \mathrm{~L}$ & $\begin{array}{l}\text { Leakage containment } \\
\& \text { removal control }\end{array}$ \\
\hline Pit internal volume & $1.39 E+04 \mathrm{ft} 3$ & $3.93 \mathrm{E}+02 \mathrm{~m} 3$ & Input parameter \\
\hline Confined volume aerosol conce & & 7.14E-05 L/m3 & \\
\hline Confined volume aerosol conce & & $1.00 \mathrm{E}-01 \mathrm{~g} / \mathrm{m} 3$ & Quasi-equilibrium Concen- \\
\hline Aerosol release rate from confir & ume & 7.79E-06 L/s & tration(PNL-4154) \\
\hline Onsite aerosol release from pit & & 2.80E-02 L & $6.00 \mathrm{E}+01$ minutes \\
\hline Pit aerosol release in $24 \mathrm{hr}$ & & $2.80 \mathrm{E}-02 \mathrm{~L}$ & $1.44 \mathrm{E}+03$ minutes \\
\hline Summary of Releases and Rat & & & \\
\hline Peak Onsite aerosol release ra & & 7.79E-06 L/s & \\
\hline Peak 24 hr release rate (pit) & & 7.79E-06 L/s & \\
\hline Total Onsite aerosol release & & $2.80 \mathrm{E}-02 \mathrm{~L}$ & \\
\hline Total $24 \mathrm{hr}$ aerosol release & & 2.80E-02 L & \\
\hline
\end{tabular}


TWR-3738, Rev. 1

\section{5/5 AWF Waste/20 gpm Leak for Limiting Pit Size-HNF5147}

Pumped leak quantity $=$

24 hour leak quantity $=$

Transfer Line Length $=$

Valve pit volume $=$

Radiological Consequences

\begin{tabular}{|l|c|l|c|c|}
\hline Pathway & \multicolumn{2}{|c|}{ Onsite MEI EDE (SV) } & \multicolumn{2}{|c|}{ Offsite MEl EDE (Sv) } \\
\hline Inhalation & $2.72 \mathrm{E}-02$ & & $2.26 \mathrm{E}-05$ & \\
ingestion & $\mathrm{NA}$ & & $3.91 \mathrm{E}-07$ & \\
Gamma-ray & $0.00 \mathrm{E}+00$ & & $\mathrm{NA}$ & \\
Total & $2.72 \mathrm{E}-02$ & & $2.30 \mathrm{E}-05$ & \\
Anticipated Guideline & $5.00 \mathrm{E}-03$ & & $1.00 \mathrm{E}-03$ & \\
\hline
\end{tabular}

Toxicological Consequences

\begin{tabular}{|l|c|c|c|c|}
\hline Pathway & \multicolumn{2}{|l|}{ Onsite MEl (SOF) } & \multicolumn{2}{|c|}{ Offsite MEI (SOF) } \\
\hline Inhalation & $8.10 \mathrm{E}-02$ & & $1.36 \mathrm{E}-04$ & \\
\hline Guideline & $1.00 \mathrm{E}+00$ & & $1.00 \mathrm{E}+00$ & \\
\hline
\end{tabular}

File:TWR3738Rev1/PIT3738R1C
1,200 gal

$1,200 \mathrm{gal}$

$0 \mathrm{ft}$

$392.6 \mathrm{~m}^{3}$

\author{
Total time $1.00 \mathrm{E}+00$ hours \\ $6.00 \mathrm{E}+01$ minutes \\ 0.0 miles \\ $1 \mathrm{hr}$ for $\mathrm{X} / \mathrm{Q}$
}


TWR-3738, Rev. 1

95/5 AWF Waste/20 gpm Leak for Limiting Pit Size-HNF5147

Summary of Results

Pit Volume ( $\mathrm{ft} 3$ )

$1.39 \mathrm{E}+04$

$\mathrm{m}^{3} \quad 392.6$

\begin{tabular}{|c|c|c|c|c|c|}
\hline Consequences & Receptor & Conseq. & Guideline & Rev 0-B & FSAR ${ }^{\star \star}$ \\
\hline Radiological & Onsite & $2.7 \mathrm{E}-02$ & $5.0 \mathrm{E}-03$ & $5.1 \mathrm{E}-03$ & $1.8 \mathrm{E}-03$ \\
\hline & Offsite & $2.3 \mathrm{E}-05$ & $1.0 \mathrm{E}-03$ & $6.6 \mathrm{E}-06$ & $1.0 \mathrm{E}-06$ \\
\hline Toxicological & Onsite & $8.1 \mathrm{E}-02$ & $1.0 \mathrm{E}+00$ & $1.4 \mathrm{E}-01$ & \multirow{2}{*}{} \\
\hline & Offsite & $1.4 \mathrm{E}-04$ & $1.0 \mathrm{E}+00$ & $7.5 \mathrm{E}-04$ \\
\cline { 1 - 3 }
\end{tabular}

File:TWR3738Rev1/PIT3738R1C

\begin{tabular}{|r|r|r|r|r|r|r|r|}
\hline Radiological Consequences & \multicolumn{2}{|l|}{} & & & & \\
\hline & \multicolumn{2}{|l|}{ Source Terms by Mechanism(L) } & & & & \\
\hline & Pit & WetResus & Gamma & X/Q(s/m3) & BR(m3/s) & ULD(Sv/L) & Dose(Sv) \\
\hline Onsite Inhalation & & $0.00 \mathrm{E}+00$ & & $7.57 \mathrm{E}-04$ & $3.30 \mathrm{E}-04$ & $8.63 \mathrm{E}+04$ & $0.00 \mathrm{E}+00$ \\
\hline & $2.80 \mathrm{E}-02$ & & & $3.41 \mathrm{E}-02$ & $3.30 \mathrm{E}-04$ & $8.63 \mathrm{E}+04$ & $2.72 \mathrm{E}-02$ \\
\hline Gamma* & & & $0.00 \mathrm{E}+00$ & & & & $0.00 \mathrm{E}+00$ \\
\hline Onsite Total & & & & & & & $2.72 \mathrm{E}-02$ \\
\hline Offsite Inhalation & & $0.00 \mathrm{E}+00$ & NA & $4.92 \mathrm{E}-07$ & $3.30 \mathrm{E}-04$ & $8.63 \mathrm{E}+04$ & $0.00 \mathrm{E}+00$ \\
\hline & $2.80 \mathrm{E}-02$ & & NA & $2.83 \mathrm{E}-05$ & $3.30 \mathrm{E}-04$ & $8.63 \mathrm{E}+04$ & $2.26 \mathrm{E}-05$ \\
\hline Ingestion & & $0.00 \mathrm{E}+00$ & & $4.92 \mathrm{E}-07$ & & $4.92 \mathrm{E}-01$ & $0.00 \mathrm{E}+00$ \\
\hline & $2.80 \mathrm{E}-02$ & & & $2.83 \mathrm{E}-05$ & & $4.92 \mathrm{E}-01$ & $3.91 \mathrm{E}-07$ \\
\hline Offsite Total & & & & & & & $2.30 \mathrm{E}-05$ \\
\hline
\end{tabular}

${ }^{*}$ Gamma $=$ (Shine+Skyshine for Reference Leak)x(Ratio of Leak Volumes) $\times$ (Ratio of Cs137 Activities)

\begin{tabular}{|c|c|c|c|c|c|c|c|}
\hline Toxicological Consequences & & \multicolumn{2}{|c|}{} & & & \\
\hline & Initial Rates (L/s) & $\mathbf{2 4}$ hour Rates (L/s) & & & \\
\hline Location & Pit & WetResus & Pit & WetResus & Rate (L/s) & SOF Mult & SOF \\
\hline Onsite & $7.79 \mathrm{E}-06$ & $0.00 \mathrm{E}+00$ & & & $7.79 \mathrm{E}-06$ & $1.04 \mathrm{E}+04$ & $8.10 \mathrm{E}-02$ \\
\hline & & & & & & & \\
\hline Offsite & $7.79 \mathrm{E}-06$ & $0.00 \mathrm{E}+00$ & $7.79 \mathrm{E}-06$ & $0.00 \mathrm{E}+00$ & $7.79 \mathrm{E}-06$ & $1.75 \mathrm{E}+01$ & $1.36 \mathrm{E}-04$ \\
\hline
\end{tabular}

File:TWR3738Rev1/PIT3738R1C 
TWR-3738, Rev. 1

\section{7/33 AWF Waste/20 gpm Leak for Limiting Pit Size}

File:TWR3738Rev1/PIT3738R1C

Radiological Unit Liter Doses
\begin{tabular}{|l|c|c|}
\hline Waste Type & $\begin{array}{c}\text { Inhalation } \\
(\text { Sv/L })\end{array}$ & $\begin{array}{c}\text { Ingestion } \\
(\text { Sv-m^ } 3 / \mathrm{s}- \\
\mathrm{L})\end{array}$ \\
\hline $\begin{array}{l}\text { AWF Liquids } \\
\text { AWF Solids }\end{array}$ & $1.400 \mathrm{E}+03$ & $9.200 \mathrm{E}-02$ \\
\cline { 2 - 3 } $67 / 33$ Composite & $1.700 \mathrm{E}+06$ & $8.100 \mathrm{E}+00$ \\
\hline
\end{tabular}

Continuous Release SOF Multipliers (s/L)

\begin{tabular}{|l|c|c|c|c|c|c|}
\hline \multirow{2}{*}{ Waste Type } & \multicolumn{2}{|c|}{ Anticipated Frequency } & \multicolumn{2}{c|}{ Unlikely Frequency } & \multicolumn{2}{c|}{$\begin{array}{c}\text { Extremely Unlikely } \\
\text { Frequency }\end{array}$} \\
\cline { 2 - 8 } & Onsite & Offsite & Onsite & Offsite & Onsite & Offsite \\
\hline AWF Liquids & $1.000 \mathrm{E}+04$ & $8.400 \mathrm{E}+00$ & $7.5 \mathrm{E}+02$ & $8.4 \mathrm{E}+00$ & $2.1 \mathrm{E}+02$ & $6.2 \mathrm{E}-01$ \\
\cline { 2 - 8 } AWF Solids & $1.800 \mathrm{E}+04$ & $1.900 \mathrm{E}+02$ & $3.3 \mathrm{E}+03$ & $1.5 \mathrm{E}+01$ & $6.3 \mathrm{E}+02$ & $2.8 \mathrm{E}+00$ \\
\hline $67 / 33$ Composite & $1.3 \mathrm{E}+04$ & $6.8 \mathrm{E}+01$ & $1.6 \mathrm{E}+03$ & $1.1 \mathrm{E}+01$ & $3.5 \mathrm{E}+02$ & $1.5 \mathrm{E}+00$ \\
\hline
\end{tabular}

Atmospheric Dispersion Coefficients $(X / Q)$

\begin{tabular}{|l|c|c|}
\hline & Onsite & Offsite \\
\hline $95 \%, 9.8 \mathrm{~m} / \mathrm{s}$, TWR-3958 & $7.57 \mathrm{E}-04$ & $4.92 \mathrm{E}-07$ \\
\hline $99.5 \%, 1 \mathrm{~m} / \mathrm{s}$, TWR-3738 & $3.41 \mathrm{E}-02$ & $2.83 \mathrm{E}-05$ \\
\hline \multicolumn{3}{|c}{ For 1 hour } \\
\hline
\end{tabular}

Breathing Rates (m3/s)

\begin{tabular}{|l|l|}
\hline light activity & $3.3 \mathrm{E}-04$ \\
\hline $24-\mathrm{hr}$ average & $3.3 \mathrm{E}-04$ \\
\hline
\end{tabular}

Waste Cs-137 Activity (Bq/L)

Cs-137 Activity for this waste

$9.13 \mathrm{E}+10$ Cs-137 Activity, Ref. DST 95/5

$5.90 \mathrm{E}+10$

Gamma Multiplier for this waste 
TWR-3738, Rev. 1

\section{7/33 AWF Waste/20 gpm Leak for Limiting Pit Size \\ Pipe Length (feet) \\ 0.0 \\ Pit Vol. \\ $3.91 \mathrm{E}+02$ feet $^{3}$ \\ File:TWR3738Rev1/PIT3738R1C}

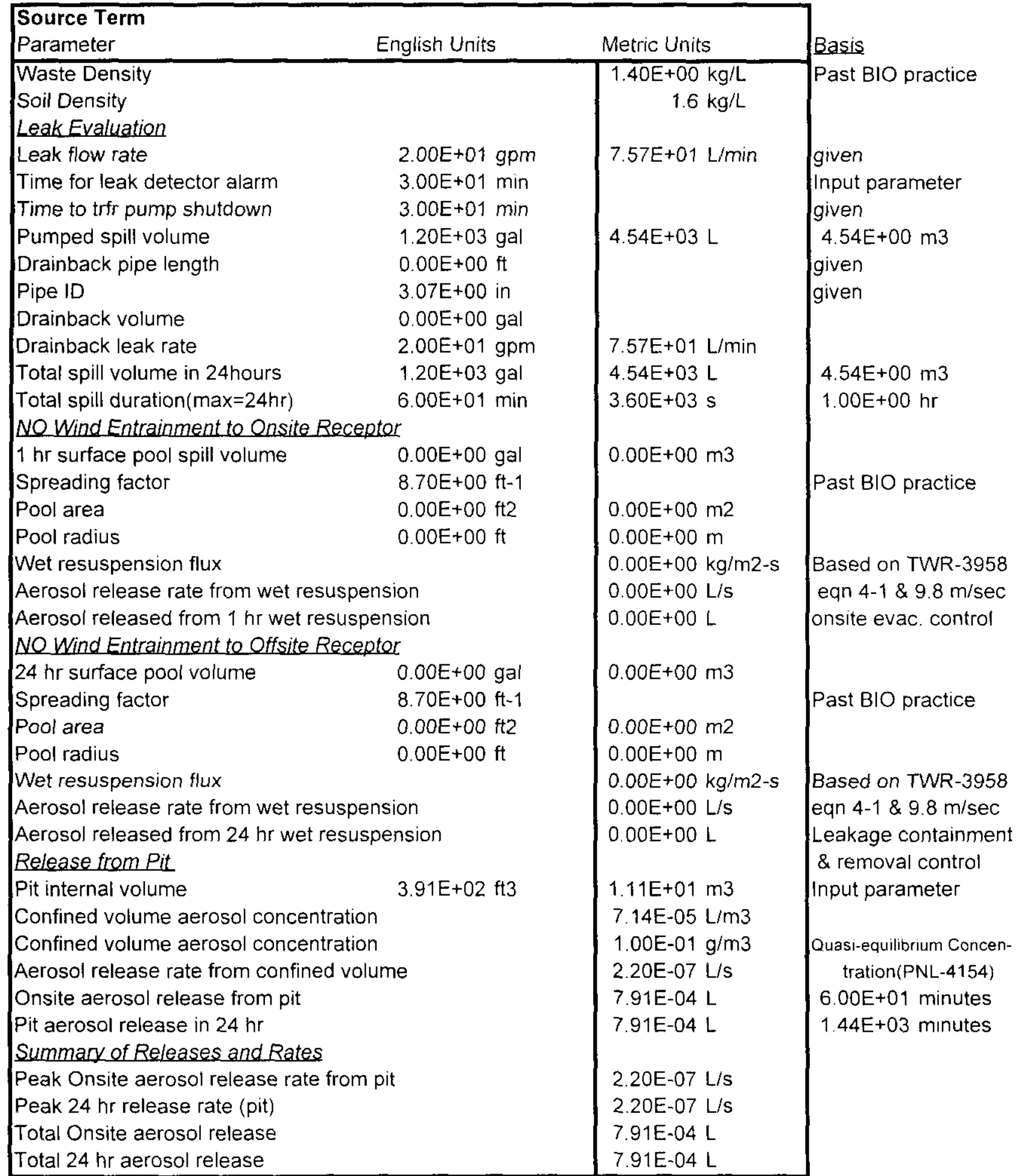


TWR-3738, Rev. 1

\section{7/33 AWF Waste/20 gpm Leak for Limiting Pit Size}

Pumped leak quantity $=$ 24 hour leak quantity $=$ Transfer Line Length $=$ Valve pit volume $=$

Radiological Consequences

\begin{tabular}{|l|c|l|c|c|}
\hline Pathway & Onsite MEI EDE (Sv) & \multicolumn{2}{|c|}{ Offsite MEI EDE (Sv) } \\
\hline Inhalation & $5.00 \mathrm{E}-03$ & & $4.15 \mathrm{E}-06$ & \\
Ingestion & NA & & $6.12 \mathrm{E}-08$ & \\
Gamma-ray & $0.00 \mathrm{E}+00$ & & NA & \\
Total & $5.00 \mathrm{E}-03$ & & $4.21 \mathrm{E}-06$ & \\
Anticipated Guideline & $5.00 \mathrm{E}-03$ & & $1.00 \mathrm{E}-03$ & \\
\hline
\end{tabular}

\section{Toxicological Consequences}

\begin{tabular}{|l|c|c|c|c|}
\hline Pathway & \multicolumn{2}{|c|}{ Onsite MEI (SOF) } & \multicolumn{2}{|c|}{ Offsite MEI (SOF) } \\
\hline Inhalation & $2.78 \mathrm{E}-03$ & & $1.50 \mathrm{E}-05$ & \\
\hline Guideline & $1.00 \mathrm{E}+00$ & & $1.00 \mathrm{E}+00$ & \\
\hline
\end{tabular}

File:TWR3738Rev1/PIT3738R1C
$1,200 \mathrm{gal}$

$1,200 \mathrm{gal}$

$0 \mathrm{ft}$

$11.08 \mathrm{~m}^{3}$

\author{
Total time $1.00 \mathrm{E}+00$ hours
} $6.00 \mathrm{E}+01$ minutes

0.0 miles

$1 \mathrm{hr}$ for $\mathrm{X} / \mathrm{Q}$ 
TWR-3738, Rev. 1

67/33 AWF Waste/20 gpm Leak for Limiting Pit Size

Summary of Results Pit Volume ( $\mathrm{ft} 3$ )

$\mathrm{m}^{3} \quad \begin{array}{cc}3.91 \mathrm{E}+02 \\ 11.08\end{array}$

\begin{tabular}{|c|c|c|c|c|c|}
\hline Consequences & Receptor & Conseq. & Guideline & Rev 0-B* & HNF-5147 \\
\hline Radiological & Onsite & $5.0 \mathrm{E}-03$ & $5.0 \mathrm{E}-03$ & $5.1 \mathrm{E}-03$ & $4.1 \mathrm{E}-02$ \\
\hline & Offsite & $4.2 \mathrm{E}-06$ & $1.0 \mathrm{E}-03$ & $6.6 \mathrm{E}-06$ & $3.7 \mathrm{E}-05$ \\
\hline Toxicological & Onsite & $2.8 \mathrm{E}-03$ & $1.0 \mathrm{E}+00$ & $1.4 \mathrm{E}-01$ & \multicolumn{1}{|c}{} \\
\hline & Offsite & $1.5 \mathrm{E}-05$ & $1.0 \mathrm{E}+00$ & $7.5 \mathrm{E}-04$ \\
\cline { 1 - 3 }
\end{tabular}

File:TWR3738Rev1/PIT3738R1C

\begin{tabular}{|r|r|r|l|l|l|r|r|}
\hline Radiological Consequences & & & & & & \\
\hline & Source Terms by Mechanism(L) & & & & \\
\hline & Pit & WetResus & Gamma & X/Q(s/m3) & BR(m3/s) & ULD(Sv/L) & Dose(Sv) \\
\hline Onsite Inhalation & & $0.00 \mathrm{E}+00$ & & $7.57 \mathrm{E}-04$ & $3.30 \mathrm{E}-04$ & $5.62 \mathrm{E}+05$ & $0.00 \mathrm{E}+00$ \\
\hline & $7.91 \mathrm{E}-04$ & & & $3.41 \mathrm{E}-02$ & $3.30 \mathrm{E}-04$ & $5.62 \mathrm{E}+05$ & $5.00 \mathrm{E}-03$ \\
\hline Gamma & & & $0.00 \mathrm{E}+00$ & & & & $0.00 \mathrm{E}+00$ \\
\hline Onsite Total & & & & & & & $5.00 \mathrm{E}-03$ \\
\hline Offsite Inhalation & & $0.00 \mathrm{E}+00$ & NA & $4.92 \mathrm{E}-07$ & $3.30 \mathrm{E}-04$ & $5.62 \mathrm{E}+05$ & $0.00 \mathrm{E}+00$ \\
\hline & $7.91 \mathrm{E}-04$ & & NA & $2.83 \mathrm{E}-05$ & $3.30 \mathrm{E}-04$ & $5.62 \mathrm{E}+05$ & $4.15 \mathrm{E}-06$ \\
\hline Ingestion & & $0.00 \mathrm{E}+00$ & & $4.92 \mathrm{E}-07$ & & $2.73 \mathrm{E}+00$ & $0.00 \mathrm{E}+00$ \\
\hline & $7.91 \mathrm{E}-04$ & & & $2.83 \mathrm{E}-05$ & & $2.73 \mathrm{E}+00$ & $6.12 \mathrm{E}-08$ \\
\hline Offsite Total & & & & & & & $4.21 \mathrm{E}-06$ \\
\hline
\end{tabular}

${ }^{\star}$ Gamma $=($ Shine+Skyshine for Reference Leak) $\times$ (Ratio of Leak Volumes) $\times$ (Ratio of Cs137 Activities)

\begin{tabular}{|c|c|c|c|c|c|c|c|}
\hline Toxicological Consequences & & & & & & \\
\hline & Initial Rates (L/s) & 24 hour Rates (L/s) & & & \\
\hline Location & Pit & WetResus & Pit & WetResus & Rate (L/s) & SOF Mult & SOF \\
\hline Onsite & $2.20 \mathrm{E}-07$ & $0.00 \mathrm{E}+00$ & & & $2.20 \mathrm{E}-07$ & $1.26 \mathrm{E}+04$ & $2.78 \mathrm{E}-03$ \\
\hline & & & & & & & \\
\hline Offsite & $2.20 \mathrm{E}-07$ & $0.00 \mathrm{E}+00$ & $2.20 \mathrm{E}-07$ & $0.00 \mathrm{E}+00$ & $2.20 \mathrm{E}-07$ & $6.83 \mathrm{E}+01$ & $1.50 \mathrm{E}-05$ \\
\hline
\end{tabular}

File:TWR3738Rev1/PIT3738R1C 
TWR-3738, Rev. 1

\section{5/5 AWF Waste/20 gpm Leak for Limiting Pit Size}

File:TWR3738Rev1/PIT3738R1C

Radiological Unit Liter Doses

\begin{tabular}{|l|c|c|}
\hline Waste Type & $\begin{array}{c}\text { Ingestion } \\
\text { Inhalation } \\
(\mathrm{SV} / \mathrm{L})\end{array}$ & $\begin{array}{c}\left(\mathrm{S} v-\mathrm{m}^{\wedge} 3 / \mathrm{s}-\right. \\
\mathrm{L})\end{array}$ \\
\hline AWF Liquids & $1.400 \mathrm{E}+03$ & $9.200 \mathrm{E}-02$ \\
AWF Solids & $1.700 \mathrm{E}+06$ & $8.100 \mathrm{E}+00$ \\
$95 / 5$ Composite & $8.633 \mathrm{E}+04$ & $4.924 \mathrm{E}-01$ \\
\hline
\end{tabular}

Continuous Release SOF Multipliers (s/L)

\begin{tabular}{|l|c|c|c|c|c|c|}
\hline \multirow{2}{*}{ Waste Type } & \multicolumn{2}{|c|}{ Anticipated Frequency } & Unlikely Frequency & \multicolumn{2}{c|}{$\begin{array}{c}\text { Fxtremely Unlikely } \\
\text { Frequency }\end{array}$} \\
\cline { 2 - 7 } & Onsite & Offsite & Onsite & Offsite & Onsite & Offsite \\
\hline AWF Liquids & $1.000 \mathrm{E}+04$ & $8.400 \mathrm{E}+00$ & $7.5 \mathrm{E}+02$ & $8.4 \mathrm{E}+00$ & $2.1 \mathrm{E}+02$ & $6.2 \mathrm{E}-01$ \\
AWF Solids & $1.800 \mathrm{E}+04$ & $1.900 \mathrm{E}+02$ & $3.3 \mathrm{E}+03$ & $1.5 \mathrm{E}+01$ & $6.3 \mathrm{E}+02$ & $2.8 \mathrm{E}+00$ \\
$95 / 5$ Composite & $1.040 \mathrm{E}+04$ & $1.748 \mathrm{E}+01$ & $8.8 \mathrm{E}+02$ & $8.7 \mathrm{E}+00$ & $2.3 \mathrm{E}+02$ & $7.3 \mathrm{E}-01$ \\
\hline
\end{tabular}

Atmospheric Dispersion Coefficients (X/Q)

\begin{tabular}{|l|c|c|}
\hline & Onsite & Offsite \\
\hline $95 \%, 9.8 \mathrm{~m} / \mathrm{s}$, TWR-3958 & $7.57 \mathrm{E}-04$ & $4.92 \mathrm{E}-07$ \\
\hline $99.5 \%, 1 \mathrm{~m} / \mathrm{s}$, TWR-3738 & $3.41 \mathrm{E}-02$ & $2.83 \mathrm{E}-05$ \\
\hline
\end{tabular}

For 1 hour For 1 hour

Breathing Rates (m3/s)

\begin{tabular}{|l|l|}
\hline light activity & $3.3 \mathrm{E}-04$ \\
\hline 24-hr average & $3.3 \mathrm{E}-04$ \\
\hline
\end{tabular}

Waste Cs-137 Activity (Bq/L)

\begin{tabular}{|l|l|}
\hline Cs-137 Activity for this waste & $8.85 \mathrm{E}+10$ \\
\hline Cs-137 Activity, Ref. DST 95/5 & $5.90 \mathrm{E}+10$ \\
\hline Gamma Multiplier for this waste & $1.50 \mathrm{E}+00$ \\
\hline
\end{tabular}


TWR-3738, Rev. 1

\section{5/5 AWF Waste/20 gpm Leak for Limiting Pit Size}

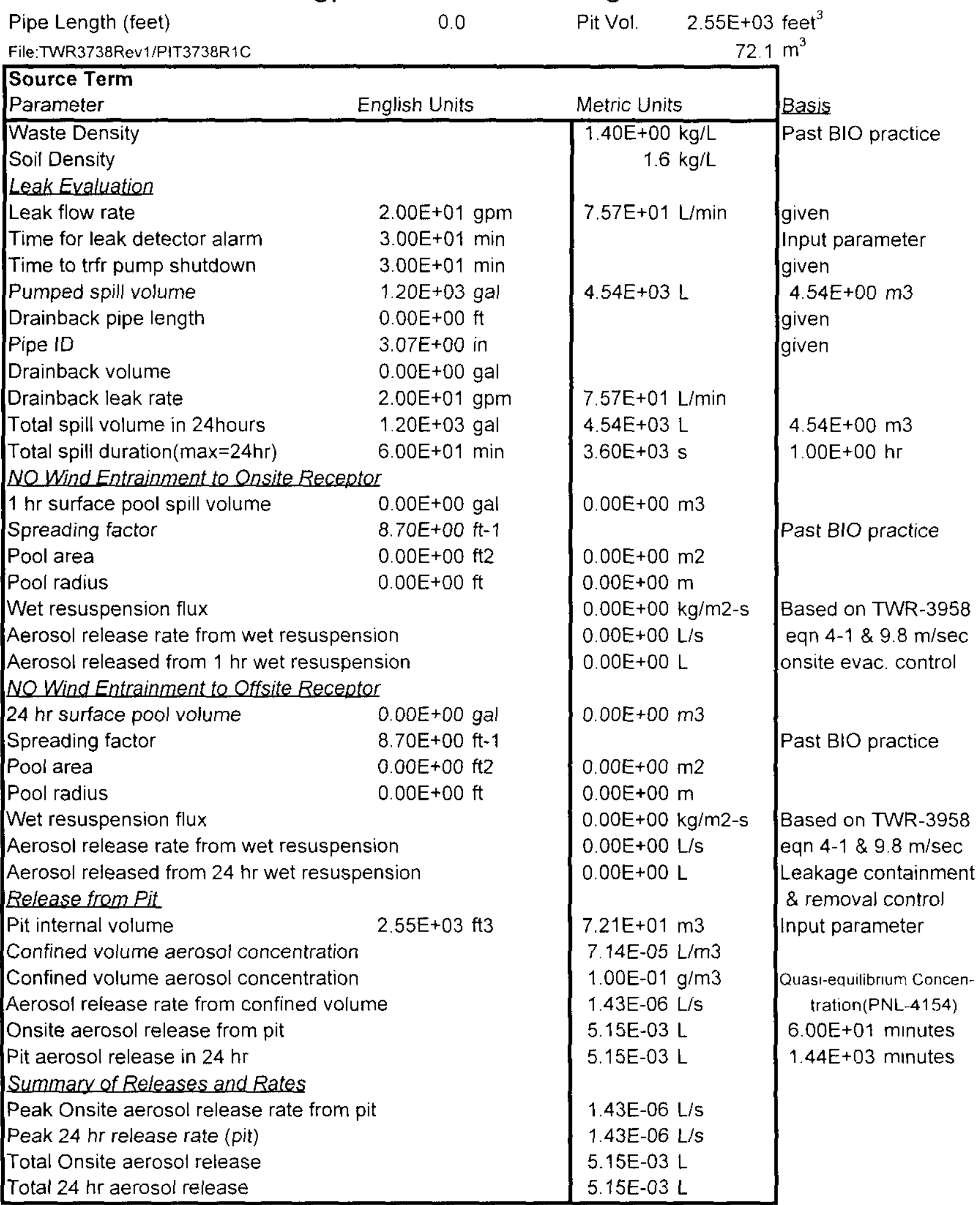


TWR-3738, Rev. 1

\section{5/5 AWF Waste/20 gpm Leak for Limiting Pit Size}

Pumped leak quantity $=$

24 hour leak quantity =

Transfer Line Length $=$

Valve pit volume $=$

Radiological Consequences

\begin{tabular}{|l|c|c|c|c|}
\hline Pathway & \multicolumn{2}{|c|}{ Onsite MEI EDE (Sv) } & \multicolumn{2}{|c|}{ Offsite MEl EDE (Sv) } \\
\hline Inhalation & $5.00 \mathrm{E}-03$ & & $4.15 \mathrm{E}-06$ & \\
Ingestion & NA & & $7.18 \mathrm{E}-08$ & \\
Gamma-ray & $0.00 \mathrm{E}+00$ & & NA & \\
Total & $5.00 \mathrm{E}-03$ & & $4.22 \mathrm{E}-06$ & \\
Anticipated Guideline & $5.00 \mathrm{E}-03$ & & $1.00 \mathrm{E}-03$ & \\
\hline
\end{tabular}

Toxicological Consequences

\begin{tabular}{|l|c|l|l|l|}
\hline Pathway & Onsite MEI (SOF) & \multicolumn{2}{|l|}{ Offsite MEI (SOF) } \\
\hline Inhalation & $1.49 \mathrm{E}-02$ & & $2.50 \mathrm{E}-05$ & \\
\hline Guideline & $1.00 \mathrm{E}+00$ & & $1.00 \mathrm{E}+00$ & \\
\hline
\end{tabular}

File:TWR3738Rev1/PIT3738R1C
$1,200 \mathrm{gal}$

$1,200 \mathrm{gal}$

$0 \mathrm{ft}$

$72.1 \mathrm{~m}^{3}$
Total time $1.00 \mathrm{E}+00$ hours $6.00 \mathrm{E}+01$ minutes

0.0 miles

$1 \mathrm{hr}$ for $\mathrm{X} / \mathrm{Q}$ 
TWR-3738, Rev. 1

95/5 AWF Waste/20 gpm Leak for Limiting Pit Size

Summary of Results $\quad$ Pit Volume ( $\mathrm{ft} 3$ )

\section{$2.55 E+03$}

$\mathrm{m}^{3} \quad 72.1$

\begin{tabular}{|c|c|c|c|c|c|}
\hline Consequences & Receptor & Conseq. & Guideline & Rev 0-B & HNF-5147 \\
\hline Radiological & Onsite & $5.0 \mathrm{E}-03$ & $5.0 \mathrm{E}-03$ & $5.1 \mathrm{E}-03$ & $4.1 \mathrm{E}-02$ \\
\hline & Offsite & $4.2 \mathrm{E}-06$ & $1.0 \mathrm{E}-03$ & $6.6 \mathrm{E}-06$ & $3.7 \mathrm{E}-05$ \\
\hline Toxicological & Onsite & $1.5 \mathrm{E}-02$ & $1.0 \mathrm{E}+00$ & $1.4 \mathrm{E}-01$ & \multicolumn{1}{|c}{} \\
\hline & Offsite & $2.5 \mathrm{E}-05$ & $1.0 \mathrm{E}+00$ & $7.5 \mathrm{E}-04$ \\
\hline
\end{tabular}

File:TWR3738Rev1/PIT3738R1C

\begin{tabular}{|r|r|r|r|r|r|r|r|}
\hline Radiological Consequences & \multicolumn{2}{|l|}{} & & & & \\
\hline & Source Terms by Mechanism(L) & & & & \\
\hline & Pit & WetResus & Gamma & X/Q(s/m3) & BR(m3/s) & ULD(Sv/L) & Dose(Sv) \\
\hline Onsite Inhalation & & $0.00 \mathrm{E}+00$ & & $7.57 \mathrm{E}-04$ & $3.30 \mathrm{E}-04$ & $8.63 \mathrm{E}+04$ & $0.00 \mathrm{E}+00$ \\
\hline & $5.15 \mathrm{E}-03$ & & & $3.41 \mathrm{E}-02$ & $3.30 \mathrm{E}-04$ & $8.63 \mathrm{E}+04$ & $5.00 \mathrm{E}-03$ \\
\hline Gamma* & & & $0.00 \mathrm{E}+00$ & & & & $0.00 \mathrm{E}+00$ \\
\hline Onsite Total & & & & & & & $5.00 \mathrm{E}-03$ \\
\hline Offsite Inhalation & & $0.00 \mathrm{E}+00$ & $\mathrm{NA}$ & $4.92 \mathrm{E}-07$ & $3.30 \mathrm{E}-04$ & $8.63 \mathrm{E}+04$ & $0.00 \mathrm{E}+00$ \\
\hline & $5.15 \mathrm{E}-03$ & & $\mathrm{NA}$ & $2.83 \mathrm{E}-05$ & $3.30 \mathrm{E}-04$ & $8.63 \mathrm{E}+04$ & $4.15 \mathrm{E}-06$ \\
\hline Ingestion & & $0.00 \mathrm{E}+00$ & & $4.92 \mathrm{E}-07$ & & $4.92 \mathrm{E}-01$ & $0.00 \mathrm{E}+00$ \\
\hline & $5.15 \mathrm{E}-03$ & & & $2.83 \mathrm{E}-05$ & & $4.92 \mathrm{E}-01$ & $7.18 \mathrm{E}-08$ \\
\hline Offsite Total & & & & & & & $4.22 \mathrm{E}-06$ \\
\hline
\end{tabular}

*Gamma = (Shine+Skyshine for Reference Leak) $\times$ (Ratio of Leak Volumes) $\times$ (Ratio of Cs137 Activities)

\begin{tabular}{|c|c|c|c|c|c|c|c|}
\hline \multicolumn{2}{|l|}{ Toxicological Consequences } & & & & & \\
\hline & Initial Rates (L/s) & 24 hour Rates (L/s) & & & \\
\hline Location & Pit & WetResus & Pit & WetResus & Rate (L/s) & SOF Mult & SOF \\
\hline Onsite & $1.43 \mathrm{E}-06$ & $0.00 \mathrm{E}+00$ & & & $1.43 \mathrm{E}-06$ & $1.04 \mathrm{E}+04$ & $1.49 \mathrm{E}-02$ \\
\hline & & & & & & & \\
\hline Offsite & $1.43 \mathrm{E}-06$ & $0.00 \mathrm{E}+00$ & $1.43 \mathrm{E}-06$ & $0.00 \mathrm{E}+00$ & $1.43 \mathrm{E}-06$ & $1.75 \mathrm{E}+01$ & $2.50 \mathrm{E}-05$ \\
\hline
\end{tabular}

File:TWR3738Rev1/PIT3738R1C 
TWR-3738, Rev. 1

\section{7/33 DST Waste/20 gpm Leak for Limiting Pit Size}

File:TWR3738Rev1/PIT3738R1B

DST Radiological Unit Liter Doses

\begin{tabular}{|l|cc|}
\hline & $\begin{array}{c}\text { Inhalation } \\
\text { Waste Type }\end{array}$ & $\begin{array}{c}\text { Ingestion } \\
\text { (Sv/L) }\end{array}$ \\
\hline DST Liquids & $\mathrm{L})$ \\
\hline DST Solids & $6.1 \mathrm{E}+03$ & $6.8 \mathrm{E}-02$ \\
$67 / 33$ Composite & $5.3 \mathrm{E}+05$ & $4.8 \mathrm{E}-01$ \\
\hline
\end{tabular}

DST Continuous Release SOF Multipliers ( $\mathrm{s} / \mathrm{L}$ )

\begin{tabular}{|c|c|c|c|c|c|c|}
\hline \multirow[b]{2}{*}{ Waste Type } & \multicolumn{2}{|c|}{$\begin{array}{l}\text { Anticipated } \\
\text { Frequency }\end{array}$} & \multicolumn{2}{|c|}{ Unlikely Frequency } & \multicolumn{2}{|c|}{$\begin{array}{c}\text { Extremely Unlikely } \\
\text { Frequency }\end{array}$} \\
\hline & Onsite & Offsite & Onsite & Offsite & Onsite & Offsite \\
\hline DST Liquids & $1.0 \mathrm{E}+04$ & $8.4 \mathrm{E}+00$ & $7.5 E+02$ & $8.4 \mathrm{E}+00$ & $2.1 E+02$ & $6.2 E-01$ \\
\hline DST Solids & $1.8 E+04$ & $1.9 E+02$ & $3.3 E+03$ & $1.5 E+01$ & $6.3 \mathrm{E}+02$ & $2.8 E+00$ \\
\hline 67/33 Composite & $1.3 E+04$ & $6.8 E+01$ & 1.6E+03 & 1.1E+01 & $3.5 \mathrm{E}+02$ & $1.3 \mathrm{E}+00$ \\
\hline
\end{tabular}

Atmospheric Dispersion Coefficients (X/Q)

\begin{tabular}{|l|c|c|}
\hline & Onsite & Offsite \\
\hline $95 \%, 9.8 \mathrm{~m} / \mathrm{s}$, TWR & $7.57 \mathrm{E}-04$ & $4.92 \mathrm{E}-07$ \\
\hline $99.5 \%, 1 \mathrm{~m} / \mathrm{s}$, TWR & $3.41 \mathrm{E}-02$ & $2.83 \mathrm{E}-05$ \\
\hline \multicolumn{3}{|c}{ For 1 hour } \\
\hline
\end{tabular}

Breathing Rates ( $\mathrm{m} 3 / \mathrm{s})$

light activity

24-hr average
3.3E-04

3.3E-04 Note LA rate
Waste Cs-137 Activity (Bq/L) Cs-137 Activity for this waste Cs-137 Activity, Ref. DST 95/5 $5.90 \mathrm{E}+10$ $5.90 \mathrm{E}+10$ Gamma Multiplier for this waste 


\section{7/33 DST Waste/20 gpm Leak for Limiting Pit Size}
Pipe Length (feet)
0.0
Pit Vol.
$1.24 \mathrm{E}+03$ feet $^{3}$
File:TWR3738Rev1/PIT3738R1B $35 \mathrm{~m}^{3}$

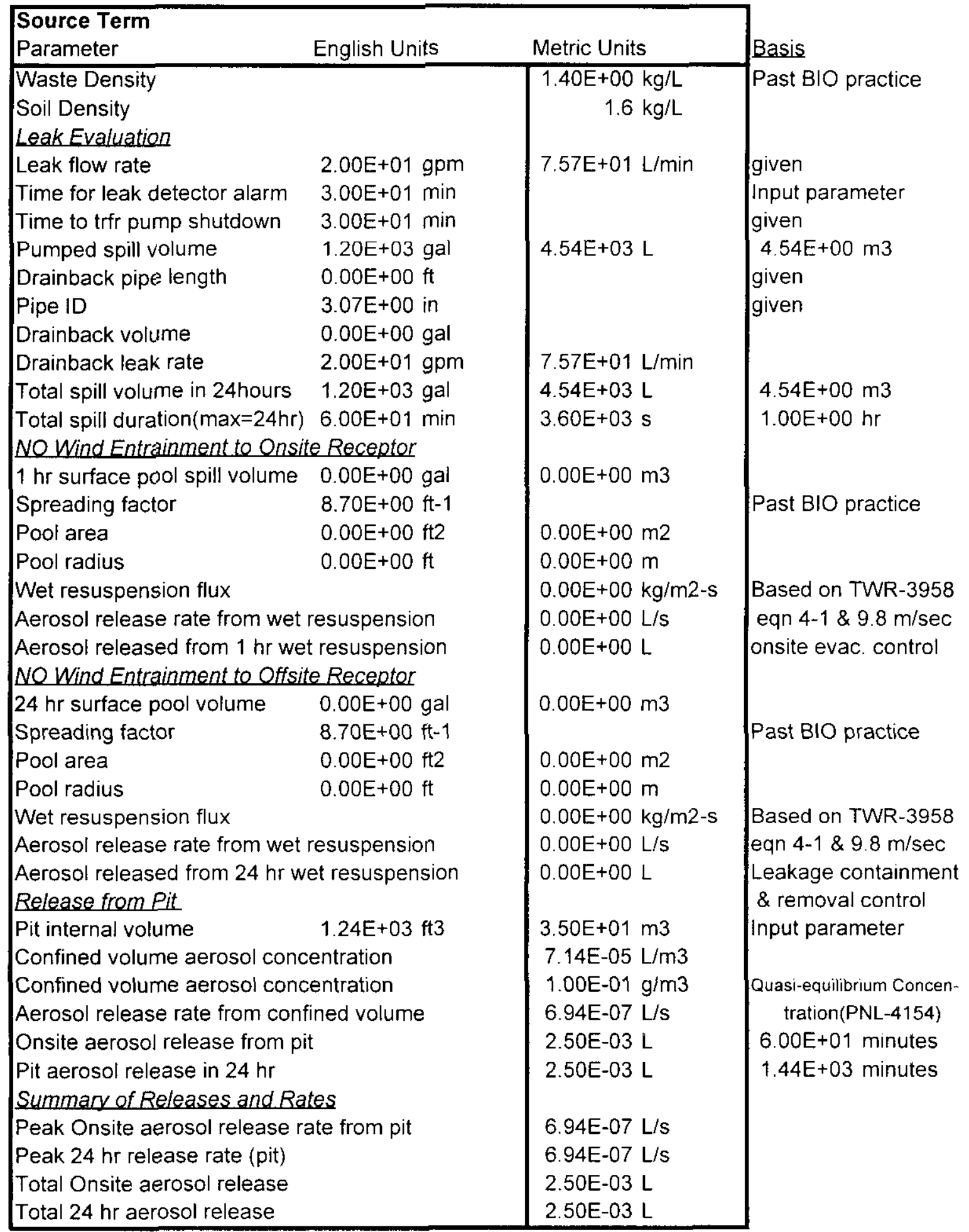


TWR-3738, Rev. 1

\section{7/33 DST Waste/20 gpm Leak for Limiting Pit Size}

Pumped leak quantity =

24 hour leak quantity =

Transfer Line Length =

Valve pit volume $=$

Radiological Consequences

\begin{tabular}{|l|c|l|c|l|}
\hline Pathway & \multicolumn{2}{|l|}{ Onsite MEI EDE (Sv) } & \multicolumn{2}{|c|}{ Offsite MEI EDE (Sv) } \\
\hline Inhalation & $5.04 \mathrm{E}-03$ & & $4.18 \mathrm{E}-06$ & \\
Ingestion & NA & & $1.44 \mathrm{E}-08$ & \\
Gamma-ray & $0.00 \mathrm{E}+00$ & & NA & \\
Total & $5.04 \mathrm{E}-03$ & & $4.19 \mathrm{E}-06$ & \\
Anticipated Guidel & $5.00 \mathrm{E}-03$ & & $1.00 \mathrm{E}-03$ & \\
\hline
\end{tabular}

Toxicological Consequences

\begin{tabular}{|l|c|l|l|l|l|}
\hline Pathway & \multicolumn{2}{|c|}{ Onsite MEI (SOF) } & \multicolumn{2}{|c|}{ Offsite MEI (SOF) } \\
\hline Inhalation & $8.78 \mathrm{E}-03$ & & $4.75 \mathrm{E}-05$ & \\
\hline Guideline & $1.00 \mathrm{E}+00$ & & $1.00 \mathrm{E}+00$ & \\
\hline
\end{tabular}

File:TWR3738Rev1/PIT3738R1B
$1,200 \mathrm{gal}$

$1,200 \mathrm{gal}$

$0 \mathrm{ft}$

$35 \mathrm{~m}^{3}$
Total time $1.00 \mathrm{E}+00$ hours $6.00 \mathrm{E}+01$ minutes

0.0 miles

$1 \mathrm{hr}$ for $\mathrm{X} / \mathrm{Q}$

. 
TWR-3738, Rev. 1

67/33 DST Waste/20 gpm Leak for Limiting Pit Size

$\begin{array}{lcc}\text { Summary of Results } \quad \text { Pit Volume }(\mathrm{ft} 3) & 1.24 \mathrm{E}+03 \\ \mathrm{~m}^{3} & 35\end{array}$

\begin{tabular}{|c|c|c|c|c|}
\hline Consequences & Receptor & Conseq. & Guideline & Rev 0-B \\
\hline Radiological & Onsite & $5.0 \mathrm{E}-03$ & $5.0 \mathrm{E}-03$ & $5.1 \mathrm{E}-03$ \\
\hline & Offsite & $4.2 \mathrm{E}-06$ & $1.0 \mathrm{E}-03$ & $6.6 \mathrm{E}-06$ \\
\hline Toxicological & Onsite & $8.8 \mathrm{E}-03$ & $1.0 \mathrm{E}+00$ & $1.4 \mathrm{E}-01$ \\
\hline & Offsite & $4.7 \mathrm{E}-05$ & $1.0 \mathrm{E}+00$ & $7.5 \mathrm{E}-04$ \\
\hline
\end{tabular}

File:TWR3738Rev1/PIT3738R1B

\begin{tabular}{|r|r|r|r|r|r|r|r|}
\hline \multicolumn{2}{|l|}{ Radiological Consequences } & & & & \\
\hline & Source Terms by Mechanism(L) & & & \\
\hline & Pit & WetResus & Gamma & X/Q(s/m3) & BR(m3/s) & ULD(Sv/L) & Dose(Sv) \\
\hline Onsite Inhalation & & $0.00 \mathrm{E}+00$ & & $7.57 \mathrm{E}-04$ & $3.30 \mathrm{E}-04$ & $1.79 \mathrm{E}+05$ & $0.00 \mathrm{E}+00$ \\
\hline & $2.50 \mathrm{E}-03$ & & & $3.41 \mathrm{E}-02$ & $3.30 \mathrm{E}-04$ & $1.79 \mathrm{E}+05$ & $5.04 \mathrm{E}-03$ \\
\hline Gamma* & & $0.00 \mathrm{E}+00$ & & & & $0.00 \mathrm{E}+00$ \\
\hline Onsite Total & & & & & & & $5.04 \mathrm{E}-03$ \\
\hline Offsite Inhalation & & $0.00 \mathrm{E}+00$ & NA & $4.92 \mathrm{E}-07$ & $3.30 \mathrm{E}-04$ & $1.79 \mathrm{E}+05$ & $0.00 \mathrm{E}+00$ \\
\hline & $2.50 \mathrm{E}-03$ & & NA & $2.83 \mathrm{E}-05$ & $3.30 \mathrm{E}-04$ & $1.79 \mathrm{E}+05$ & $4.18 \mathrm{E}-06$ \\
\hline Ingestion & & $0.00 \mathrm{E}+00$ & & $4.92 \mathrm{E}-07$ & & $2.04 \mathrm{E}-01$ & $0.00 \mathrm{E}+00$ \\
\hline & $2.50 \mathrm{E}-03$ & & & $2.83 \mathrm{E}-05$ & & $2.04 \mathrm{E}-01$ & $1.44 \mathrm{E}-08$ \\
\hline Offsite Total & & & & & & & $4.19 \mathrm{E}-06$ \\
\hline
\end{tabular}

${ }^{\star}$ Gamma $=($ Shine+Skyshine for Reference Leak) $x$ (Ratio of Leak Volumes) $\times$ (Ratio of Cs137 Activities)

\begin{tabular}{|c|c|c|c|c|c|c|c|}
\hline Toxicological Consequences & \multicolumn{2}{|l|}{} & & & & \\
\hline & Initial Rates (L/s) & \multicolumn{2}{|c|}{ 24 hour Rates (L/s) } & & & \\
\hline Location & Pit & WetResus & Pit & WetResus & Rate (L/s) & SOF Mult & SOF \\
\hline Onsite & $6.94 \mathrm{E}-07$ & $0.00 \mathrm{E}+00$ & & & $6.94 \mathrm{E}-07$ & $1.26 \mathrm{E}+04$ & $8.78 \mathrm{E}-03$ \\
\hline & & & & & & & \\
\hline Offsite & $6.94 \mathrm{E}-07$ & $0.00 \mathrm{E}+00$ & $6.94 \mathrm{E}-07$ & $0.00 \mathrm{E}+00$ & $6.94 \mathrm{E}-07$ & $6.83 \mathrm{E}+01$ & $4.75 \mathrm{E}-05$ \\
\hline
\end{tabular}

File:TWR3738Rev1/PIT3738R1B 
TWR-3738, Rev. 1

\section{5/5 DST Waste/20 gpm Leak for Limiting Pit Size}

File:TWR3738Rev1/PIT3738R1B

DST Radiological Unit Liter Doses

\begin{tabular}{|l|c|c|}
\hline & $\begin{array}{c}\text { Inhalation } \\
\text { Waste Type }\end{array}$ & $\begin{array}{c}\text { Ingestion } \\
\left(\text { Sv-m }-\mathrm{m}^{\wedge} 3 / \mathrm{s}\right) \\
\mathrm{L})\end{array}$ \\
\hline DST Liquids & $6.1 \mathrm{E}+03$ & $6.8 \mathrm{E}-02$ \\
DST Solids & $5.3 \mathrm{E}+05$ & $4.8 \mathrm{E}-01$ \\
95/5 Composite & $3.2 \mathrm{E}+04$ & $8.9 \mathrm{E}-02$ \\
\hline
\end{tabular}

DST Continuous Release SOF Multipliers ( $\mathrm{s} / \mathrm{L}$ )

\begin{tabular}{|c|c|c|c|c|c|c|}
\hline & \multicolumn{2}{|c|}{$\begin{array}{l}\text { Anticipated } \\
\text { Frequency }\end{array}$} & \multicolumn{2}{|c|}{ Unlikely Frequency } & \multicolumn{2}{|c|}{$\begin{array}{c}\text { Extremely Unlikely } \\
\text { Frequency }\end{array}$} \\
\hline Waste Type & Onsite & Offsite & Onsite & Offsite & Onsite & Offsite \\
\hline DST Liquids & $1.0 \mathrm{E}+04$ & $8.4 \mathrm{E}+00$ & $7.5 E+02$ & $8.4 E+00$ & $2.1 \mathrm{E}+02$ & $6.2 \mathrm{E}-01$ \\
\hline DST Solids & $1.8 E+04$ & $1.9 E+02$ & $3.3 E+03$ & $1.5 \mathrm{E}+01$ & $6.3 \mathrm{E}+02$ & $2.8 \mathrm{E}+00$ \\
\hline 95/5 Composite & $1.0 E+04$ & $1.7 E+01$ & $8.8 E+02$ & $8.7 E+00$ & $2.3 E+02$ & 7.3E-01 \\
\hline
\end{tabular}

Atmospheric Dispersion Coefficients (X/Q)

\begin{tabular}{|c|c|c|}
\hline & Onsite & Offsite \\
\hline $95 \%, 9.8 \mathrm{~m} / \mathrm{s}$, TWR & $7.57 \mathrm{E}-04$ & $4.92 \mathrm{E}-07$ \\
\hline $99.5 \%, 1 \mathrm{~m} / \mathrm{s}, \mathrm{TWR}$ & $3.41 \mathrm{E}-02$ & $2.83 \mathrm{E}-05$ \\
\hline \multicolumn{3}{|c}{ For 1 hour For 1 hour }
\end{tabular}

Breathing Rates (m3/s)

\begin{tabular}{|l|r|}
\hline light activity & $3.3 \mathrm{E}-04$ \\
\hline $24-h r$ average & $3.3 \mathrm{E}-04$ \\
\hline
\end{tabular}

Waste Cs-137 Activity (Bq/L) Cs-137 Activity for this waste Cs-137 Activity, Ref. DST 95/5 Gamma Multiplier for this waste $5.90 \mathrm{E}+10$ $5.90 \mathrm{E}+10$ $1.00 \mathrm{E}+00$ 
TWR-3738, Rev. 1

95/5 DST Waste/20 gpm Leak for Limiting Pit Size

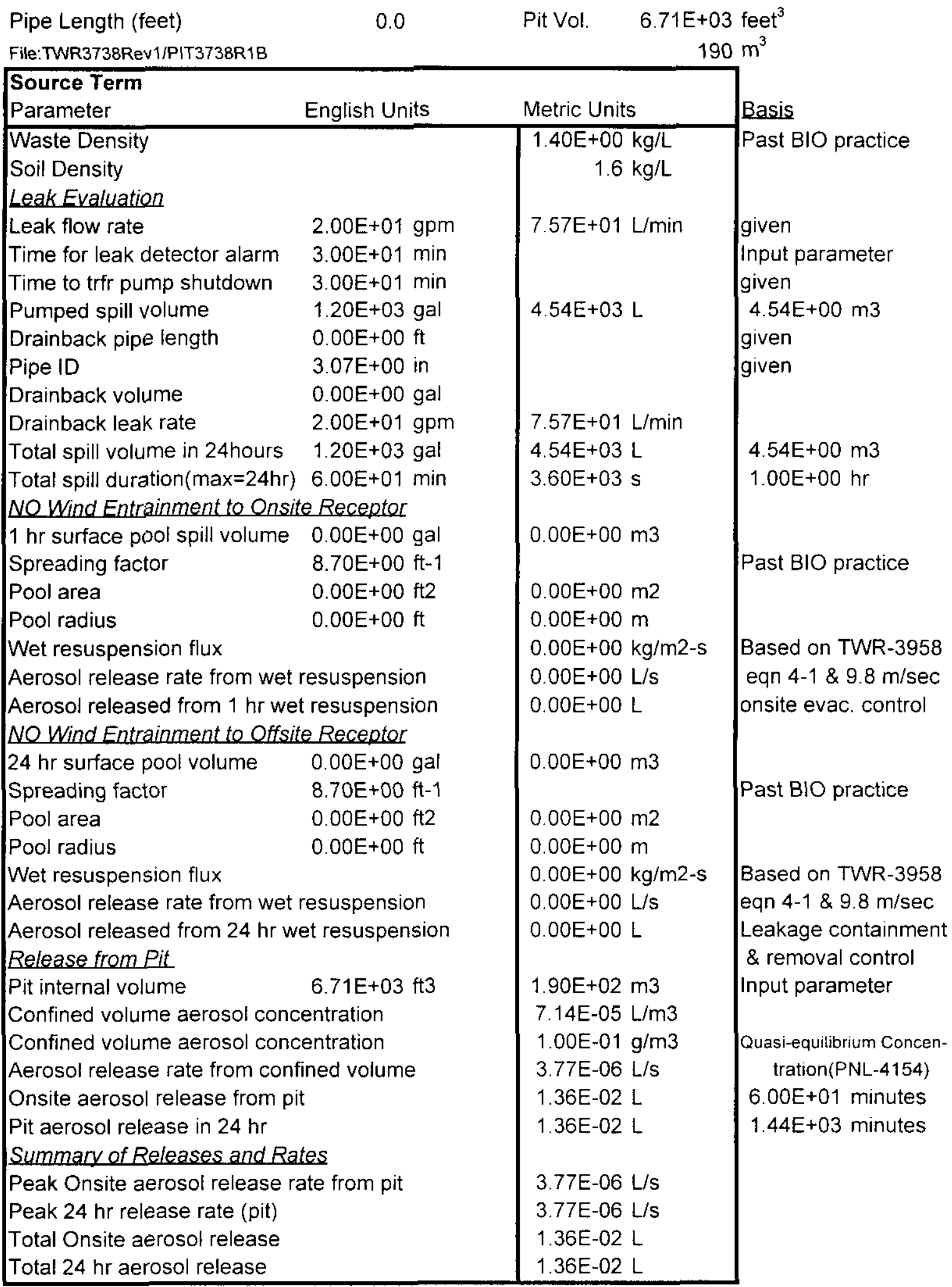


TWR-3738, Rev. 1

\section{5/5 DST Waste/20 gpm Leak for Limiting Pit Size}

Pumped leak quantity =

24 hour leak quantity =

Transfer Line Length =

Valve pit volume $=$

Radiological Consequences

\begin{tabular}{|l|c|l|l|l|}
\hline Pathway & Onsite MEI EDE (Sv) & \multicolumn{2}{|c|}{ Offsite MEI EDE (Sv) } \\
\hline Inhalation & $4.93 \mathrm{E}-03$ & & $4.09 \mathrm{E}-06$ & \\
Ingestion & NA & & $3.40 \mathrm{E}-08$ & \\
Gamma-ray & $0.00 \mathrm{E}+00$ & & NA & \\
Total & $4.93 \mathrm{E}-03$ & & $4.13 \mathrm{E}-06$ & \\
Anticipated Guidel & $5.00 \mathrm{E}-03$ & & $1.00 \mathrm{E}-03$ & \\
\hline
\end{tabular}

Toxicological Consequences

\begin{tabular}{|l|c|l|l|l|}
\hline Pathway & \multicolumn{2}{|c|}{ Onsite MEI (SOF) } & \multicolumn{2}{|c|}{ Offsite MEI (SOF) } \\
\hline Inhalation & $3.92 \mathrm{E}-02$ & & $6.59 \mathrm{E}-05$ & \\
\hline Guideline & $1.00 \mathrm{E}+00$ & & $1.00 \mathrm{E}+00$ & \\
\hline
\end{tabular}

File:TWR3738Rev1/PIT3738R1B

\author{
$1,200 \mathrm{gal}$ \\ $1,200 \mathrm{gal}$ \\ $0 \mathrm{ft}$ \\ $190 \mathrm{~m}^{3}$
Total time $1.00 \mathrm{E}+00$ hours $6.00 \mathrm{E}+01$ minutes
0.0 miles
$1 \mathrm{hr}$ for $\mathrm{X} / \mathrm{Q}$


TWR-3738, Rev. 1

95/5 DST Waste/20 gpm Leak for Limiting Pit Size

$\begin{array}{ccc}\text { Summary of Results } & \text { Pit Volume ( } \mathrm{ft} 3 \text { ) } & 6.71 \mathrm{E}+03 \\ \mathrm{~m}^{3} & 190\end{array}$

\begin{tabular}{|c|c|c|c|c|}
\hline Consequences & Receptor & Conseq. & Guideline & Rev 0-B \\
\hline Radiological & Onsite & $4.9 \mathrm{E}-03$ & $5.0 \mathrm{E}-03$ & $5.1 \mathrm{E}-03$ \\
\hline & Offsite & $4.1 \mathrm{E}-06$ & $1.0 \mathrm{E}-03$ & $6.6 \mathrm{E}-06$ \\
\hline Toxicological & Onsite & $3.9 \mathrm{E}-02$ & $1.0 \mathrm{E}+00$ & $1.4 \mathrm{E}-01$ \\
\hline & Offsite & $6.6 \mathrm{E}-05$ & $1.0 \mathrm{E}+00$ & $7.5 \mathrm{E}-04$ \\
\hline
\end{tabular}

File:TWR3738Rev1/PIT3738R1B

\begin{tabular}{|c|c|c|c|c|c|c|c|}
\hline \multicolumn{3}{|c|}{ Radiological Consequences } & & & \multirow[b]{3}{*}{$\mathrm{BR}(\mathrm{m} 3 / \mathrm{s})$} & \multirow[b]{3}{*}{ ULD(Sv/L) } & \multirow[b]{3}{*}{ Dose(Sv) } \\
\hline & \multicolumn{4}{|c|}{ Source Terms by Mechanism(L) } & & & \\
\hline & Pit & WetResus & Gamma & $\mathrm{X} / \mathrm{Q}(\mathrm{s} / \mathrm{m} 3)$ & & & \\
\hline Onsite Inhalation & & $0.00 E+00$ & & $7.57 \mathrm{E}-04$ & $3.30 \mathrm{E}-04$ & $3.23 E+04$ & $0.00 \mathrm{E}+00$ \\
\hline & $1.36 \mathrm{E}-02$ & & & $3.41 \mathrm{E}-02$ & $3.30 \mathrm{E}-04$ & $3.23 E+04$ & $4.93 \mathrm{E}-03$ \\
\hline $\mathrm{Ga}$ & $\mathrm{mma}^{*}$ & & $0.00 \mathrm{E}+00$ & & & & $0.00 \mathrm{E}+00$ \\
\hline Onsite Total & & & & & & & 4.93E-03 \\
\hline Offsite Inhalation & & $0.00 \mathrm{E}+00$ & $\mathrm{NA}$ & 4.92E-07 & $3.30 \mathrm{E}-04$ & $3.23 E+04$ & $0.00 \mathrm{E}+00$ \\
\hline & $1.36 \mathrm{E}-02$ & & $\overline{\mathrm{NA}}$ & $2.83 \mathrm{E}-05$ & $3.30 \mathrm{E}-04$ & $3.23 E+04$ & $4.09 \mathrm{E}-06$ \\
\hline Ingestion & & $0.00 \mathrm{E}+00$ & & $4.92 \mathrm{E}-07$ & & $8.86 \mathrm{E}-02$ & $0.00 \mathrm{E}+00$ \\
\hline & $1.36 \mathrm{E}-02$ & & & 2.83E-05 & & $8.86 \mathrm{E}-02$ & $3.40 \mathrm{E}-08$ \\
\hline Offsite Total & & & & & & & 4.13E-06 \\
\hline
\end{tabular}

*Gamma = (Shine+Skyshine for Reference Leak) $\times$ (Ratio of Leak Volumes) $\times$ (Ratio of Cs137 Activities)

\begin{tabular}{|c|c|c|c|c|c|c|c|}
\hline Toxicological Consequences & \multicolumn{2}{|c|}{} & & & \\
\hline & Initial Rates (L/s) & $\mathbf{2 4}$ hour Rates (L/s) & & & \\
\hline Location & Pit & WetResus & Pit & WetResus & Rate (L/s) & SOF Mult & SOF \\
\hline Onsite & $3.77 \mathrm{E}-06$ & $0.00 \mathrm{E}+00$ & & & $3.77 \mathrm{E}-06$ & $1.04 \mathrm{E}+04$ & $3.92 \mathrm{E}-02$ \\
\hline & & & & & & & \\
\hline Offsite & $3.77 \mathrm{E}-06$ & $0.00 \mathrm{E}+00$ & $3.77 \mathrm{E}-06$ & $0.00 \mathrm{E}+00$ & $3.77 \mathrm{E}-06$ & $1.75 \mathrm{E}+01$ & $6.59 \mathrm{E}-05$ \\
\hline
\end{tabular}

File:TWR3738Rev1/PIT3738R1B 
TWR-3738, Rev. 1

\section{7/33 SST Waste/20 gpm Leak for Limiting Pit Size}

File:TWR3738Rev1/PIT3738R1C

SST Radiological Unit Liter Doses

\begin{tabular}{|l|c|c|}
\hline Waste Type & $\begin{array}{c}\text { Inhalation } \\
(\mathrm{Sv} / \mathrm{L})\end{array}$ & $\begin{array}{c}\text { Ingestion } \\
\left(\mathrm{Sv}-\mathrm{m}^{\wedge} 3 / \mathrm{s}-\right. \\
\mathrm{L})\end{array}$ \\
\hline SST Liquids & $1.1 \mathrm{E}+04$ & $5.2 \mathrm{E}-02$ \\
SST Solids & $2.2 \mathrm{E}+05$ & $4.1 \mathrm{E}+00$ \\
\hline 67/33 Composite & $8.0 \mathrm{E}+04$ & $1.4 \mathrm{E}+00$ \\
\hline
\end{tabular}

SST Continuous Release SOF Multipliers (S/L)

\begin{tabular}{|l|c|c|c|c|c|c|}
\hline \multirow{2}{*}{ Waste Type } & \multicolumn{2}{|c|}{ Anticipated Frequency } & \multicolumn{2}{c|}{ Unlikely Frequency } & \multicolumn{2}{c|}{$\begin{array}{c}\text { Fxtremely Unlikely } \\
\text { Frequency }\end{array}$} \\
\cline { 2 - 7 } & Onsite & Offsite & Onsite & Offsite & Onsite & Offsite \\
\cline { 5 - 8 } & $9.6 \mathrm{E}+03$ & $8.0 \mathrm{E}+00$ & $7.5 \mathrm{E}+02$ & $8.0 \mathrm{E}+00$ & $2.0 \mathrm{E}+02$ & $6.2 \mathrm{E}-01$ \\
SST Liquids & $4.0 \mathrm{E}+04$ & $9.4 \mathrm{E}+01$ & $2.1 \mathrm{E}+04$ & $3.3 \mathrm{E}+01$ & $1.0 \mathrm{E}+03$ & $1.7 \mathrm{E}+01$ \\
SST Solids & $2.0 \mathrm{E}+04$ & $3.6 \mathrm{E}+01$ & $7.4 \mathrm{E}+03$ & $1.6 \mathrm{E}+01$ & $4.6 \mathrm{E}+02$ & $6.2 \mathrm{E}+00$ \\
\hline
\end{tabular}

Atmospheric Dispersion Coefficients (X/Q)

\begin{tabular}{|c|c|c|}
\hline & Onsite & Offsite \\
\hline $95 \%, 9.8 \mathrm{~m} / \mathrm{s}$, TWR-3958 & $7.57 \mathrm{E}-04$ & $4.92 \mathrm{E}-07$ \\
\hline $99.5 \%, 1 \mathrm{~m} / \mathrm{s}$, TWR-3738 & $3.41 \mathrm{E}-02$ & $2.83 \mathrm{E}-05$ \\
\hline \multicolumn{3}{|c}{ For 1 hour } \\
\hline
\end{tabular}

Breathing Rates $(\mathrm{m} 3 / \mathrm{s})$

light activity

24-hr average
Waste Cs-137 Activity (Bq/L)

Cs-137 Activity for this waste Cs-137 Activity, Ref. DST 95/5

Gamma Multiplier for this waste
$4.77 \mathrm{E}+10$

$5.90 \mathrm{E}+10$

$8.08 \mathrm{E}-01$ 
TWR-3738, Rev. 1

\section{7/33 SST Waste/20 gpm Leak for Limiting Pit Size}

Pipe Length (feet)

File:TWR3738Rev1/PIT3738R1C
0.0

Pit Vol.

2.75E+03 feet ${ }^{3}$

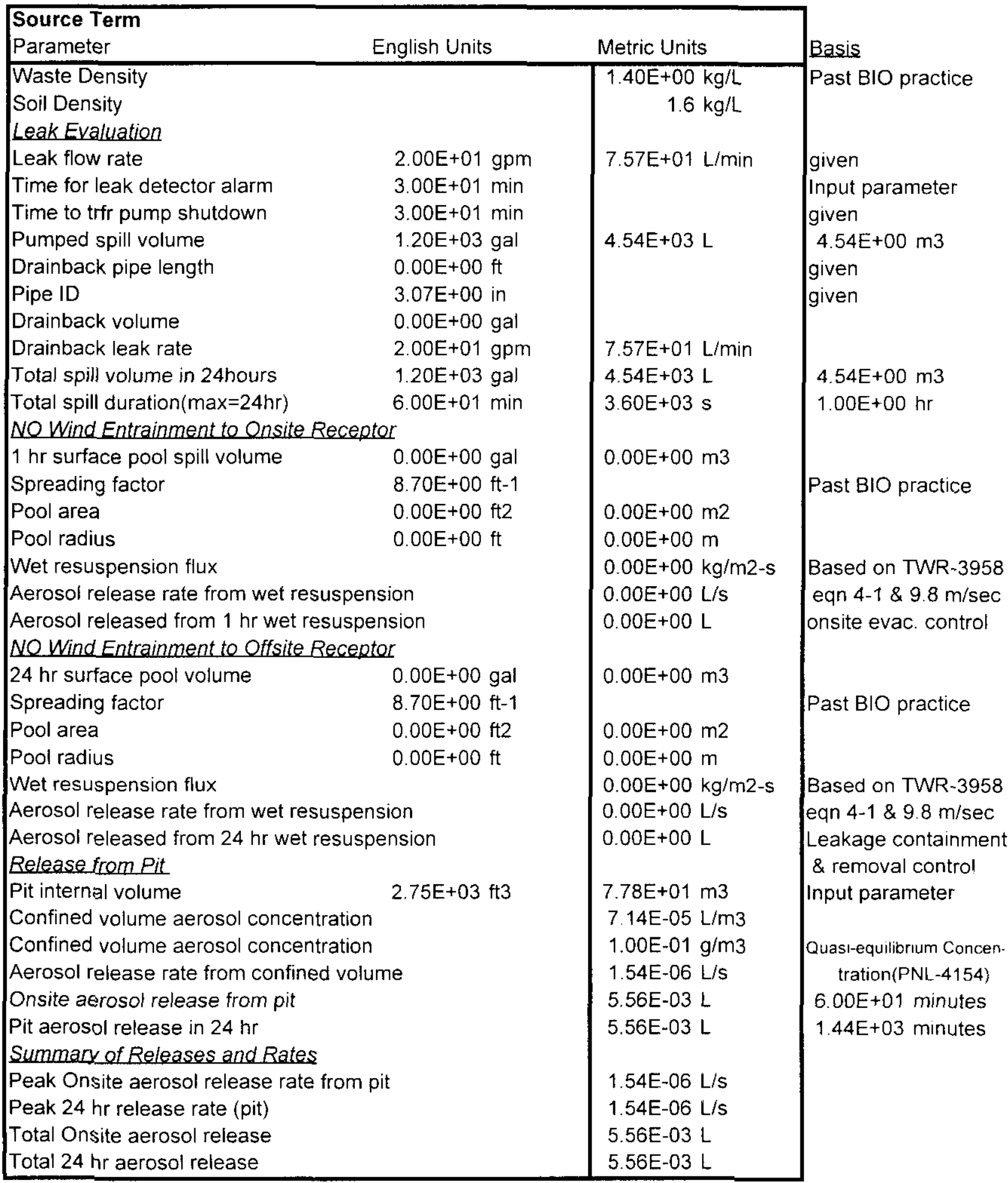


TWR-3738, Rev. 1

\section{7/33 SST Waste/20 gpm Leak for Limiting Pit Size}

Pumped leak quantity =

24 hour leak quantity $=$

Transfer Line Length =

Valve pit volume $=$

Radiological Consequences

\begin{tabular}{|c|c|c|}
\hline Pathway & Onsite MEI EDE (SV) & Offsite MEI EDE (Sv) \\
\hline Inhalation & 5.00E-03 & $4.15 E-06$ \\
\hline Ingestion & NA & 2.18E-07 \\
\hline Gamma-ray & $0.00 \mathrm{E}+00$ & NA \\
\hline Total & 5.00E-03 & 4.37E-06 \\
\hline Anticipated Guideline & $5.00 E-03$ & 1.00E-03 \\
\hline
\end{tabular}

Toxicological Consequences

\begin{tabular}{|l|c|l|c|l|}
\hline Pathway & \multicolumn{2}{|c|}{ Onsite MEl (SOF) } & \multicolumn{2}{|c|}{ Offsite MEI (SOF) } \\
\hline Inhalation & $3.03 \mathrm{E}-02$ & & $5.62 \mathrm{E}-05$ & \\
\hline Guideline & $1.00 \mathrm{E}+00$ & & $1.00 \mathrm{E}+00$ & \\
\hline
\end{tabular}

File:TWR3738Rev1/PIT3738R1C

$\begin{array}{ccc}1,200 \mathrm{gal} & \text { Total time } & 1.00 \mathrm{E}+00 \text { hours } \\ 1,200 \mathrm{gal} & 6.00 \mathrm{E}+01 \text { minutes } & \\ 0 \mathrm{ft} & 0.0 \text { miles } & 1 \mathrm{hr} \text { for } \mathrm{X} / \mathrm{Q} \\ 77.8 \mathrm{~m}^{3} & & \end{array}$

$77.8 \mathrm{~m}^{3}$ 
TWR-3738, Rev. 1

67/33 SST Waste/20 gpm Leak for Limiting Pit Size

Summary of Results $\quad$ Pit Volume (ft3)

$2.75 \mathrm{E}+03$

$\mathrm{m}^{3} \quad 77.8$

\begin{tabular}{|c|c|c|c|c|c|}
\hline Consequences & Receptor & Conseq. & Guideline & Rev 0-B* & HNF-5147 \\
\hline Radiological & Onsite & $5.0 \mathrm{E}-03$ & $5.0 \mathrm{E}-03$ & $5.1 \mathrm{E}-03$ & $4.1 \mathrm{E}-02$ \\
\hline & Offsite & $4.4 \mathrm{E}-06$ & $1.0 \mathrm{E}-03$ & $6.6 \mathrm{E}-06$ & $3.7 \mathrm{E}-05$ \\
\hline Toxicological & Onsite & $3.0 \mathrm{E}-02$ & $1.0 \mathrm{E}+00$ & $1.4 \mathrm{E}-01$ & \multicolumn{1}{|c}{} \\
\hline & Offsite & $5.6 \mathrm{E}-05$ & $1.0 \mathrm{E}+00$ & $7.5 \mathrm{E}-04$ \\
\cline { 1 - 4 } & & &
\end{tabular}

File:TWR3738Rev1/PIT3738R1C

\begin{tabular}{|r|r|r|r|r|r|r|r|}
\hline \multicolumn{2}{|l|}{ Radiological Consequences } & \multicolumn{2}{|l|}{} & & & & \\
\hline & Source Terms by Mechanism(L) & & & & \\
\hline & Pit & WetResus & Gamma & X/Q(s/m3) & BR(m3/s) & ULD(Sv/L) & Dose(Sv) \\
\hline Onsite Inhalation & & $0.00 \mathrm{E}+00$ & & $7.57 \mathrm{E}-04$ & $3.30 \mathrm{E}-04$ & $8.00 \mathrm{E}+04$ & $0.00 \mathrm{E}+00$ \\
\hline & $5.56 \mathrm{E}-03$ & & & $3.41 \mathrm{E}-02$ & $3.30 \mathrm{E}-04$ & $8.00 \mathrm{E}+04$ & $5.00 \mathrm{E}-03$ \\
\hline Gamma* & & & $0.00 \mathrm{E}+00$ & & & & $0.00 \mathrm{E}+00$ \\
\hline Onsite Total & & & & & & & $5.00 \mathrm{E}-03$ \\
\hline Offsite Inhalation & & $0.00 \mathrm{E}+00$ & NA & $4.92 \mathrm{E}-07$ & $3.30 \mathrm{E}-04$ & $8.00 \mathrm{E}+04$ & $0.00 \mathrm{E}+00$ \\
\hline & $5.56 \mathrm{E}-03$ & & NA & $2.83 \mathrm{E}-05$ & $3.30 \mathrm{E}-04$ & $8.00 \mathrm{E}+04$ & $4.15 \mathrm{E}-06$ \\
\hline Ingestion & & $0.00 \mathrm{E}+00$ & & $4.92 \mathrm{E}-07$ & & $1.39 \mathrm{E}+00$ & $0.00 \mathrm{E}+00$ \\
\hline & $5.56 \mathrm{E}-03$ & & & $2.83 \mathrm{E}-05$ & & $1.39 \mathrm{E}+00$ & $2.18 \mathrm{E}-07$ \\
\hline Offsite Total & & & & & & & $4.37 \mathrm{E}-06$ \\
\hline
\end{tabular}

*Gamma = (Shine+Skyshine for Reference Leak)x(Ratio of Leak Volumes) $\times$ (Ratio of Cs137 Activities)

\begin{tabular}{|c|c|c|c|c|c|c|c|}
\hline Toxicological Consequences & & & & & & \\
\hline & Initial Rates (L/s) & 24 hour Rates (L/s) & & & \\
\hline Location & Pit & WetResus & Pit & WetResus & Rate (L/s) & SOF Mult & SOF \\
\hline Onsite & $1.54 \mathrm{E}-06$ & $0.00 \mathrm{E}+00$ & & & $1.54 \mathrm{E}-06$ & $1.96 \mathrm{E}+04$ & $3.03 \mathrm{E}-02$ \\
\hline & & & & & & & \\
\hline Offsite & $1.54 \mathrm{E}-06$ & $0.00 \mathrm{E}+00$ & $1.54 \mathrm{E}-06$ & $0.00 \mathrm{E}+00$ & $1.54 \mathrm{E}-06$ & $3.64 \mathrm{E}+01$ & $5.62 \mathrm{E}-05$ \\
\hline
\end{tabular}

File:TWR3738Rev1/PIT3738R1C 
TWR-3738, Rev. 1

\section{5/5 SST Waste/20 gpm Leak for Limiting Pit Size}

File:TWR3738Rev1/PIT3738R1B

SST Radiological Unit Liter Doses

\begin{tabular}{|l|cc|}
\hline & $\begin{array}{c}\text { Inhalation } \\
\text { Waste Type }\end{array}$ & (Sv/L) \\
\hline SST Liquids & $\mathrm{L})$ \\
\hline SST Solids & $1.1 \mathrm{E}+04$ & $5.2 \mathrm{E}-02$ \\
$95 / 5$ Composite & $2.2 \mathrm{E}+05$ & $4.1 \mathrm{E}+00$ \\
\hline
\end{tabular}

SST Continuous Release SOF Multipliers (s/L)

\begin{tabular}{|c|c|c|c|c|c|c|}
\hline \multirow[b]{2}{*}{ Waste Type } & \multicolumn{2}{|c|}{$\begin{array}{l}\text { Anticipated } \\
\text { Frequency }\end{array}$} & \multicolumn{2}{|c|}{ Unlikely Frequency } & \multicolumn{2}{|c|}{$\begin{array}{c}\text { Extremely Unlikely } \\
\text { Frequency }\end{array}$} \\
\hline & Onsite & Offsite & Onsite & Offsite & Onsite & Offsite \\
\hline SST Liquids & $9.6 \mathrm{E}+03$ & $8.0 \mathrm{E}+00$ & $7.5 E+02$ & $8.0 \mathrm{E}+00$ & $2.0 \mathrm{E}+02$ & 6.2E-01 \\
\hline SST Solids & $4.0 E+04$ & $9.4 \mathrm{E}+01$ & 2. $1 E+04$ & $3.3 E+01$ & $1.0 E+03$ & $1.7 E+01$ \\
\hline 95/5 Composite & 1.1E+04 & $1.2 E+01$ & $1.8 E+03$ & $9.3 E+00$ & $2.4 \mathrm{E}+02$ & 1. $4 \mathrm{E}+00$ \\
\hline
\end{tabular}

Atmospheric Dispersion Coefficients (X/Q)

\begin{tabular}{|c|c|c|}
\hline & Onsite & Offsite \\
\hline $95 \%, 9.8 \mathrm{~m} / \mathrm{s}$, TWR & $7.57 \mathrm{E}-04$ & $4.92 \mathrm{E}-07$ \\
\hline $99.5 \%, 1 \mathrm{~m} / \mathrm{s}$, TWR & $3.41 \mathrm{E}-02$ & $2.83 \mathrm{E}-05$ \\
\hline
\end{tabular}

For 1 hour For 1 hour

Breathing Rates $(\mathrm{m} 3 / \mathrm{s})$

\begin{tabular}{|l|r|}
\hline light activity & $3.3 \mathrm{E}-04$ \\
\hline $24-\mathrm{hr}$ average & $3.3 \mathrm{E}-04$ \\
\hline
\end{tabular}

Waste Cs-137 Activity (Bq/L)

Cs-137 Activity for this waste

Cs-137 Activity, Ref. DST 95/5

$2.59 \mathrm{E}+10$

$5.90 \mathrm{E}+10$

\begin{tabular}{|l|l|}
\hline Gamma Multiplier for this waste & $4.39 \mathrm{E}-01$ \\
\hline
\end{tabular}

-

camma Multiplier for this waste 
TWR-3738, Rev. 1

\section{5/5 SST Waste/20 gpm Leak for Limiting Pit Size}

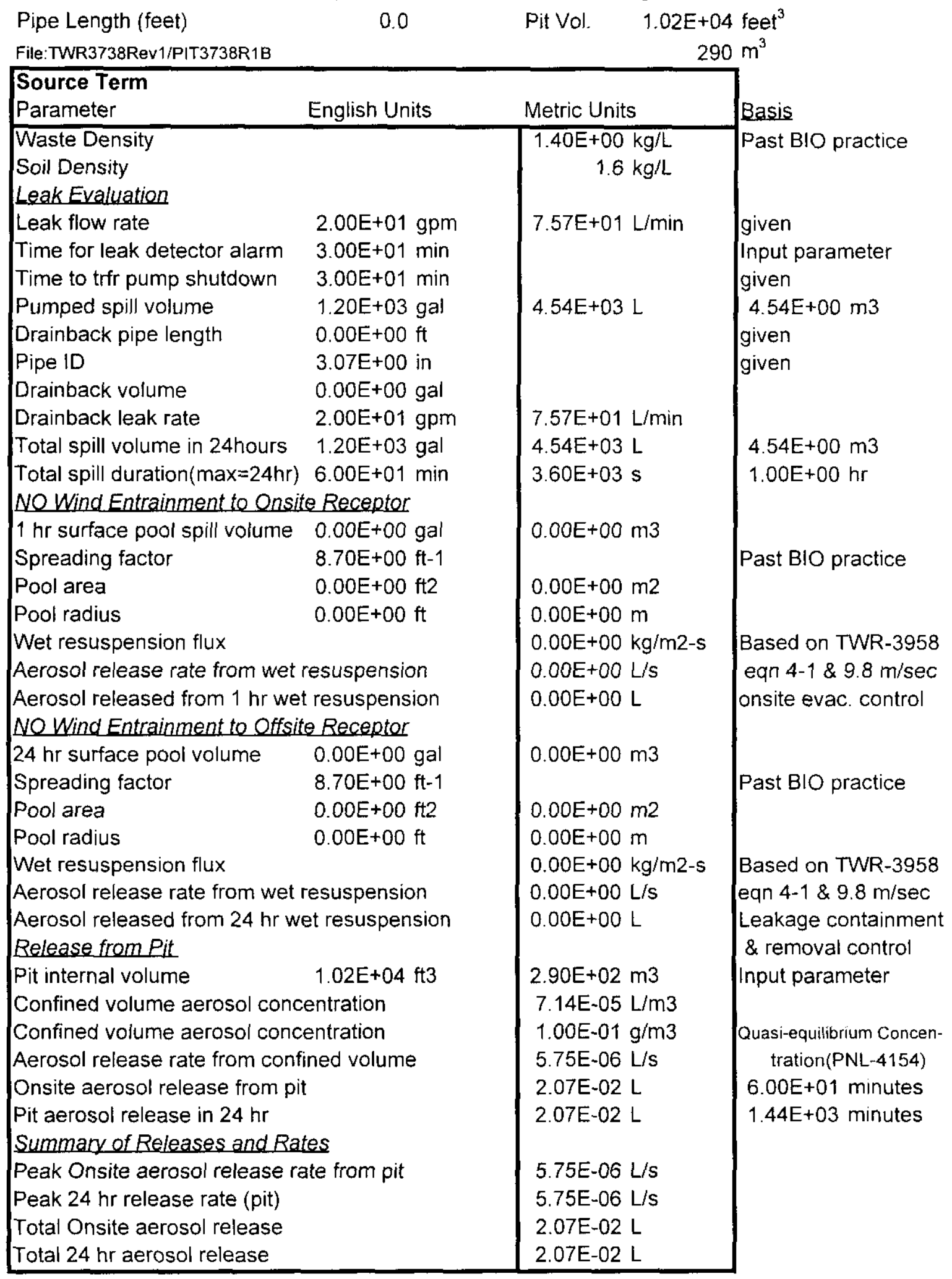


TWR-3738, Rev. 1

\section{5/5 SST Waste/20 gpm Leak for Limiting Pit Size \\ Pumped leak quantity $=$ \\ $1,200 \mathrm{gal}$ \\ Total time 1.00E+00 hours \\ $1,200 \mathrm{gal}$ \\ $0 \mathrm{ft}$ \\ $6.00 E+01$ minutes \\ Transfer Line Length $=$ \\ 290 Line vol. \\ 0.0 miles \\ $1 \mathrm{hr}$ for $\mathrm{X} / \mathrm{Q}$ \\ Valve pit volume $\left(\mathrm{m}^{3}\right)=$}

Radiological Consequences

\begin{tabular}{|l|c|l|l|l|l|}
\hline Pathway & \multicolumn{2}{|c|}{ Onsite MEI EDE (Sv) } & \multicolumn{2}{|c|}{ Offsite MEI EDE (Sv) } \\
\hline Inhalation & $5.00 \mathrm{E}-03$ & & $4.15 \mathrm{E}-06$ & \\
Ingestion & NA & & $1.49 \mathrm{E}-07$ & \\
Gamma-ray & $0.00 \mathrm{E}+00$ & & NA & \\
Total & $5.00 \mathrm{E}-03$ & & $4.30 \mathrm{E}-06$ & \\
Anticipated Guidel & $5.00 \mathrm{E}-03$ & & $1.00 \mathrm{E}-03$ & \\
\hline
\end{tabular}

Toxicological Consequences

\begin{tabular}{|l|c|l|l|l|}
\hline Pathway & \multicolumn{2}{|c|}{ Onsite MEI (SOF) } & \multicolumn{2}{|c|}{ Offsite MEI (SOF) } \\
\hline Inhalation & $6.40 \mathrm{E}-02$ & & $7.08 \mathrm{E}-05$ & \\
\hline Guideline & $1.00 \mathrm{E}+00$ & & $1.00 \mathrm{E}+00$ & \\
\hline
\end{tabular}

File:TWR3738Rev1/PIT3738R1B 
TWR-3738, Rev. 1

95/5 SST Waste/20 gpm Leak for Limiting Pit Size

Summary of Results Pit Volume ( $\mathrm{ft} 3)_{\mathrm{m}^{3}} \quad \begin{array}{cc}1.02 \mathrm{E}+04 \\ \mathrm{~m}^{3}\end{array}$

\begin{tabular}{|c|c|c|c|c|}
\hline Consequences & Receptor & Conseq. & Guideline & Rev 0-B \\
\hline Radiological & Onsite & $5.0 \mathrm{E}-03$ & $5.0 \mathrm{E}-03$ & $5.1 \mathrm{E}-03$ \\
\cline { 1 - 4 } & Offsite & $4.3 \mathrm{E}-06$ & $1.0 \mathrm{E}-03$ & $6.6 \mathrm{E}-06$ \\
\hline Toxicological & Onsite & $6.4 \mathrm{E}-02$ & $1.0 \mathrm{E}+00$ & $1.4 \mathrm{E}-01$ \\
\hline & Offsite & $7.1 \mathrm{E}-05$ & $1.0 \mathrm{E}+00$ & $7.5 \mathrm{E}-04$ \\
\hline
\end{tabular}

File:TWR3738Rev1/PIT3738R1B

\begin{tabular}{|c|c|c|c|c|c|c|c|}
\hline \multicolumn{3}{|c|}{ Radiological Consequences } & & & & \multirow[b]{3}{*}{ ULD(Sv/L) } & \multirow[b]{3}{*}{ Dose(Sv) } \\
\hline & \multicolumn{4}{|c|}{ Source Terms by Mechanism(L) } & & & \\
\hline & Pit & WetResus & Gamma & $\mathrm{X} / \mathrm{Q}(\mathrm{s} / \mathrm{m} 3)$ & $\mathrm{BR}(\mathrm{m} 3 / \mathrm{s})$ & & \\
\hline \multirow[t]{2}{*}{ Onsite Inhalation } & & $0.00 E+00$ & & 7.57E-04 & $3.30 \mathrm{E}-04$ & $2.15 E+04$ & $0.00 \mathrm{E}+00$ \\
\hline & $2.07 \mathrm{E}-02$ & & & $3.41 E-02$ & $3.30 \mathrm{E}-04$ & $2.15 \mathrm{E}+04$ & $5.00 \mathrm{E}-03$ \\
\hline \multicolumn{2}{|c|}{ Gamma* } & & $0.00 \mathrm{E}+00$ & & & & $0.00 \mathrm{E}+00$ \\
\hline Onsite Total & & & & & & & $5.00 \mathrm{E}-03$ \\
\hline \multirow[t]{2}{*}{ Offsite Inhalation } & & $0.00 \mathrm{E}+00$ & $\mathrm{NA}$ & $4.92 \mathrm{E}-07$ & $3.30 \mathrm{E}-04$ & $2.15 \mathrm{E}+04$ & $0.00 \mathrm{E}+00$ \\
\hline & 2.07E-02 & & NA & $2.83 \mathrm{E}-05$ & $3.30 \mathrm{E}-04$ & $2.15 E+04$ & $4.15 \mathrm{E}-06$ \\
\hline \multirow[t]{2}{*}{ Ingestion } & & $0.00 E+00$ & & $4.92 \mathrm{E}-07$ & & $2.54 \mathrm{E}-01$ & $0.00 \mathrm{E}+00$ \\
\hline & 2.07E-02 & & & $2.83 \mathrm{E}-05$ & & $2.54 \mathrm{E}-01$ & $1.49 \mathrm{E}-07$ \\
\hline Offsite Total & & & & & & & $4.30 \mathrm{E}-06$ \\
\hline
\end{tabular}

${ }^{\star}$ Gamma = (Shine+Skyshine for Reference Leak) $\times$ (Ratio of Leak Volumes) $\times$ (Ratio of Cs137 Activities)

\begin{tabular}{|c|c|c|c|c|c|c|c|}
\hline \multicolumn{3}{|c|}{ Toxicological Consequences } & & & & & \\
\hline & Initial Rat & es (L/s) & \multicolumn{2}{|c|}{24 hour Rates (L/s) } & & & \\
\hline Location & Pit & WetResus & Pit & WetResus & Rate (L/s) & SOF Mult & SOF \\
\hline Onsite & $5.75 \mathrm{E}-06$ & $0.00 \mathrm{E}+00$ & & & $5.75 \mathrm{E}-06$ & $1.11 E+04$ & $6.40 \mathrm{E}-02$ \\
\hline Offsite & $5.75 \mathrm{E}-06$ & $0.00 \mathrm{E}+00$ & $5.75 \mathrm{E}-06$ & $0.00 \mathrm{E}+00$ & $5.75 \mathrm{E}-06$ & $1.23 \mathrm{E}+01$ & $7.08 \mathrm{E}-05$ \\
\hline
\end{tabular}

File:TWR3738Rev1/PIT3738R1B 
TWR-3738, Rev. 1

APPENDIX C - Base Case Microshield ${ }^{T M}$ and Microskyshine ${ }^{T M}$ Calculations for DST 95/5 Waste Spill 
TWR-3738, Rev. 1

This page intentionally left blank.

C-2 
TWR-3738, Rev. 1

Materlal at Risk

$4.54 E+03 L$

DST Gamma Producing isotopes (Bq/L)

\begin{tabular}{|l|ccccc|}
\hline Waste Type & Co-60 & Sr-90 & Cs-137 & Eu-154 & EU-755 \\
\hline DST Liq. & $7.00 E+06$ & $4.60 E+09$ & $5.90 E+10$ & $4.20 E+07$ & 0 \\
DST Sol. & $1.50 E+07$ & $5.20 E+10$ & $5.90 E+10$ & $3.00 E+08$ & 0 \\
9515 Composite & $7.40 E+06$ & $6.97 E+09$ & $5.90 E+10$ & $5.49 E+07$ & $0.00 E+00$ \\
\hline
\end{tabular}

Pool Isotopic Inventory (C)

\begin{tabular}{|cccccc|}
\hline Isotope & Co-60 & Sr-90 & Cs-137 & $E$ U15 154 & EU-155 \\
\hline $9.08 E-01$ & $8.55 E+02$ & $7.24 E+03$ & $6.74 E+00$ & $0.00 E+00$ \\
\hline
\end{tabular}

Energy Spectra for 1-Cl of Given Isotopes

\begin{tabular}{|c|c|c|c|c|c|}
\hline \multicolumn{6}{|c|}{ Photons per Second } \\
\hline MeV & Co-60 & Sr-90 & Cs-137 & Eu-154 & Eu-155 \\
\hline 0.015 & & $7.80 E+08$ & 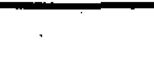 & & \\
\hline 0.025 & & $4.00 E+08$ & & & \\
\hline 0.035 & $\therefore$ & $2.60 E+08$ & & & \\
\hline 0.045 & & $1.80 E+08$ & & & \\
\hline 0.055 & & $1.40 E+08$ & & & \\
\hline 0.065 & & $1.10 \mathrm{E}+08$ & & & \\
\hline 0.075 & & $8.90 E+D 7$ & & & \\
\hline 0.085 & & $7.40 \mathrm{E}+07$ & & & \\
\hline 0.095 & & $6.30 E+07$ & & & $7.65 E+09$ \\
\hline 0.15 & & $3.30 E+08$ & & $1.50 E+10$ & \\
\hline 0.25 & & $1.30 E+08$ & & $2.53 E+09$ & \\
\hline 0.35 & & $6.90 E+07$ & & & \\
\hline 0.475 & & $5.50 E+07$ & & $2.65 E+09$ & - \\
\hline 0.65 & $6.04 E+06$ & $3.50 E+07$ & $3.15 E+10$ & & \\
\hline 0.825 & & $1.40 E+07$ & & $1.54 E+10$ & \\
\hline 1 & & $9.80 E+06$ & & 1.05E+10 & \\
\hline 1.225 & $7.40 E+10$ & $5.50 E+06$ & & $1.37 E+10$ & \\
\hline 1.475 & & $2.10 E+06$ & & & \\
\hline 1.7 & & $5.30 E+05$ & & $1.30 E+09$ & \\
\hline 1.9 & & $1.40 E+05$ & & 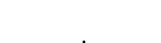 & \\
\hline 2.1 & & $1.50 E+0.4$ & & & \\
\hline 2.3 & & $8.30 E+01$ & & & \\
\hline
\end{tabular}


TWR-3738, Rev. 1

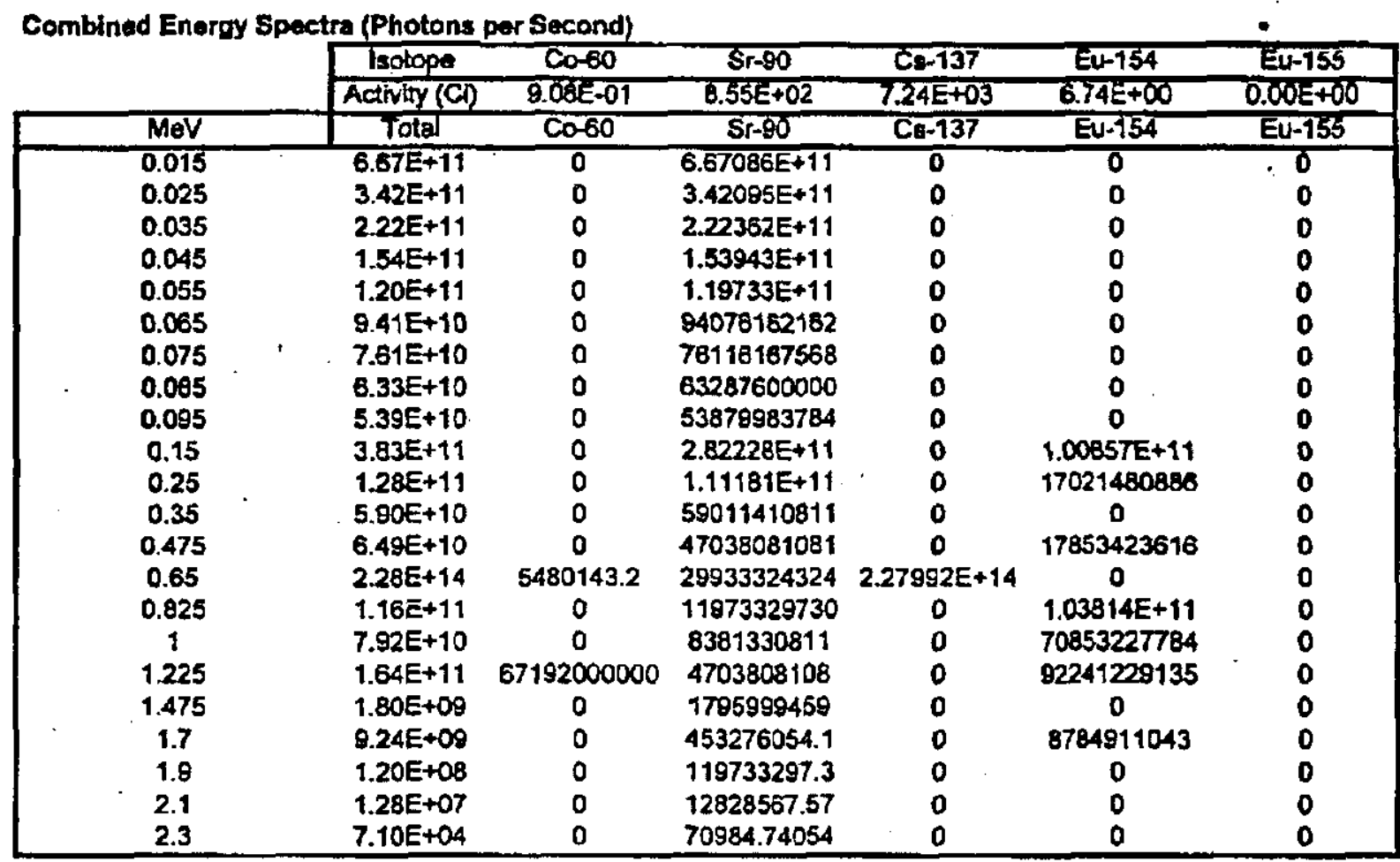


TWR-3738, Rev. 1

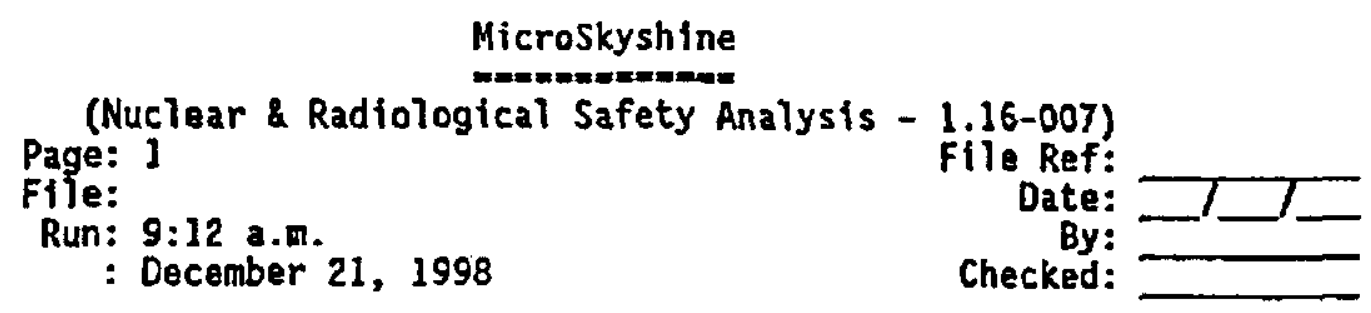

CASE: 1,200 gat Splll of 95/5 DST Waste

GEOMETRY: Vertical cylinder area source behind a wall

DIMENSIONS (meters):

Distance between wall and detector.......... $\quad 80$.

Depth of source behind wall.............. Y 1 .

offset of detector.................... $z$.

Depth of dose point..................... 1 .

Distance between center of source and wall... Rl 20 .

Thickness of cover slab................... TI 0 .

Thickness of second shield................ T2 0 .

Radius of source.....................W 6.43

Height of source..................... L 0.035052

INTEGRATION PARAMETERS:

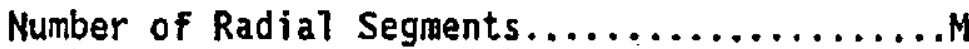

Number of Circumferential Segments............

Number of Vertical Segments...............

Quadrature Order.

MATERIAL DENSITIES ( $/ / c C)$ :

Ambient air: 0012

\begin{tabular}{llcc} 
Material Cover Slab & Lower Shield & Volume Source \\
\hline Air & & & \\
Water & & 1.4 \\
Concrete & & \\
Iron & & \\
Lead & & \\
Zirconium & & \\
Urania & & &
\end{tabular}

Buildup factor based on: CONCRETE. 
TWR-3738, Rev. 1

Page 2

\section{CASE: 1,200 gal Spill of 95/5 DST Waste \\ SOURCE NUCLIDES:}

Source was entered by energy groups.

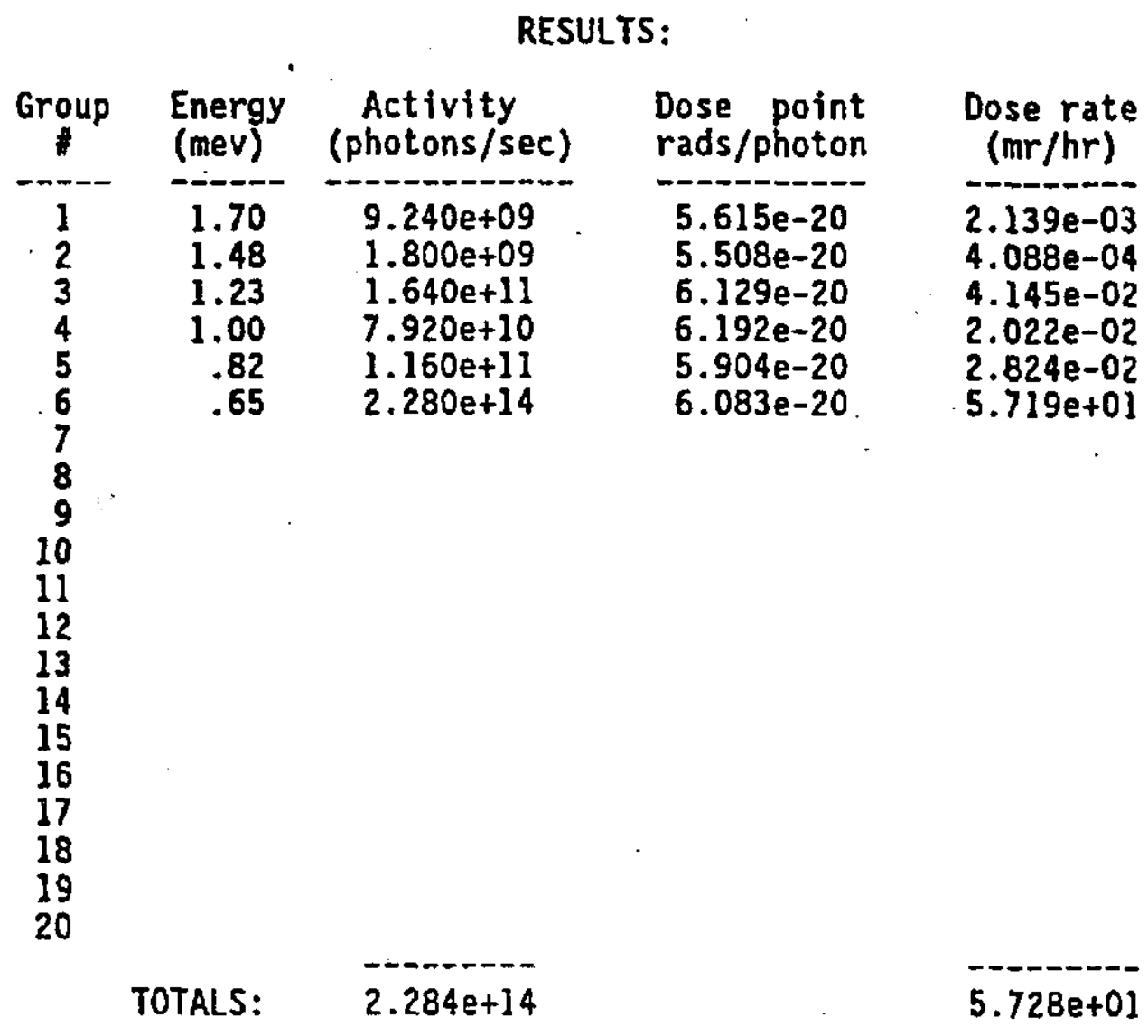


Page : 1

DOS Fi7e: DST-POOL.MS4

Run Date: December 21, 1998

Run Time: 9:16 a.m. Monday

Duration: 0:00:01
MicroShield 4.00 - Serial \$4.00-00128

Westinghouse Hanford Company

File Ref:

Checked:

Date:

By:

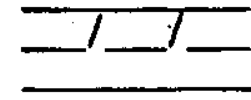

Case Title: 1,200 gal Spill of 95/5 DST Waste

GEOMETRY 8 - Cylinder Volume - End Shields

cent imeters

Dose point coordinate $X: 10000.0$

Dose point coordinate $Y: \quad 100.0$

Dose point coordinate $Z$ : $\quad 0.0$

Cyl inder height:

Cylinder radius:

Air Gap:

Side Clad: $\quad 8000.0$

3.5052

643.0

96.4948

feet and inches

328.0

3.0

1.0

3.4

0.0

.0

0.0

21.0

3.0

262.0

1.4

1.1

2.0

5.6

Source Volume: $4.55286 \mathrm{e}+6 \mathrm{~cm}^{\wedge} 3160.783 \mathrm{cu} f t .277833$. cu in.

Material

Air

Concrete

\section{Source \\ Shield}

MATERIAL DENSITIES $(\mathrm{g} / \mathrm{cm} \wedge 3)$

Air Gap Side Clad Immersion

0.00122

Shield Shield

1.4

1.4

0.00122

\section{BUILDUP}

Method: Buildup Factor Tables

The material reference is Source

Radial

Circumferential

Axial (along $Z$ )

\section{INTEGRATION PARAMETERS}

Quadrature Order

10

10

10 
TWR-3738, Rev. 1

Page : 2

DOS File: DST-POOL. MS4

Run Date: December 21, 1998

Run Time: 9:16 a.m. Monday

Title : 1,200 gal Spill of 95/5 DST Waste

\begin{tabular}{|c|c|c|c|c|c|}
\hline \multirow{2}{*}{$\begin{array}{l}\text { Energy } \\
\text { (MeV) } \\
\\
0.65 \\
0.825 \\
1.0 \\
1.225 \\
1.475 \\
1.7\end{array}$} & \multirow{2}{*}{$\begin{array}{c}\text { Activity } \\
\text { (photons/sec) } \\
\\
2.280 \mathrm{e}+014 \\
1.160 \mathrm{e}+01 \mathrm{j} \\
7.920 \mathrm{e}+010 \\
1.640 \mathrm{e}+011 \\
1.800 \mathrm{e}+009 \\
9.240 \mathrm{e}+009\end{array}$} & \multirow{2}{*}{\multicolumn{2}{|c|}{ 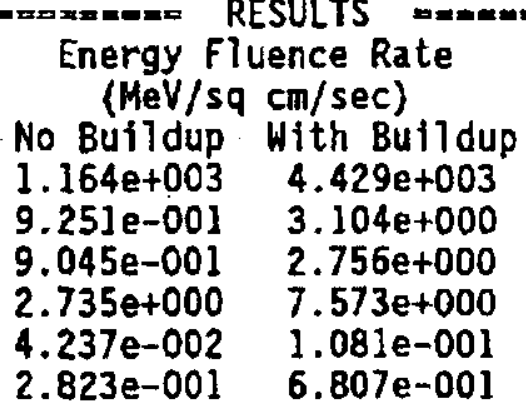 }} & \multicolumn{2}{|c|}{$\begin{array}{c}\text { Exposure Rate In Air } \\
(\mathrm{mR} / \mathrm{hr})\end{array}$} \\
\hline & & & & $\begin{array}{l}\text { No Buildup } \\
2.261 \mathrm{e}+000 \\
1.753 \mathrm{e}-003 \\
1.667 \mathrm{e}-003 \\
4.842 \mathrm{e}-003 \\
7.161 \mathrm{e}-005 \\
4.585 \mathrm{e}-004\end{array}$ & $\begin{array}{l}\text { With Buildup } \\
8.599 \mathrm{e}+000 \\
5.882 \mathrm{e}-003 \\
5.081 \mathrm{e}-003 \\
1.340 \mathrm{e}-002 \\
1.827 \mathrm{e}-004 \\
1.106 \mathrm{e}-003\end{array}$ \\
\hline TOTAL: & $2.284 e+014$ & $1.169 \mathrm{e}+003$ & $4.443 \mathrm{e}+003$ & $2.269 e+000$ & 8.62 \\
\hline
\end{tabular}


TWR-3738, Rev. 1

APPENDIX D - Record of Review, Peer Review and HEDOP Review

D-1 
TWR-3738, Rev. 1

This page intentionally left blank.

D-2 
Preparation and Review of
Calculation Notes
Manual

Desk Instruction

Page

Effective Date
HNF-2353

4.3, Rev. 0

8 of 8

June 10, 1999

\section{ATTACHMENT C}

\section{CHECKUIST FOR TECHNICAL PEER REVIEW}

Document Reviewed: TWR-3738, Rev bo Mi insated Trans fan Ling Leaks Scope of Review: Entire Document

Yes No NA

M [] [] Previous reviews are complete and cover the analysis, up to the scope of this review, with no gaps.

Q [ ] [ ] Problem is completely defined.

1] [] [] Accident scenarios are developed in a clear and logical manner.

A [] [] Necessary assumptions are explicitly stated and supported.

X] [] [] Computer codes and data files are documented.

W [ ] [ ] Data used in calculations are explicitly stated.

(1) [] [] Data were checked for consistency with original source information as applicable.

[] [] $\$ Mathematical derivations were checked including dimensional consistency of results.

W [] [] Models are appropriate and were used within their established range of validity or adequate justification was provided for use outside their established range of validity.

W [ ] [ ] Spreadsheet results and all hand calculations were verified.

W] [] [] Software input is correct and consistent with the document reviewed.

[X] [] [] Software output is consistent with the input and with the results reported in the document reviewed.

A [ [ [ ] Limits/criteria/guidelines applied to the analysis results are appropriate and referenced. Limits/criteria/guidelines were checked against references.

W [ ] : [ ] Safety margins are consistent with good engineering practices.

D] [] [ ] Conclusions are consistent with analytical results and applicable limits.

\& [ ] [ Results and conclusions address all points in the purpose.

[]

The document was prepared in accordance with HNF-2353, Section 4.3, Attachment B, "Calculation Note Format and Preparation Instructions".

[X] I] Concurrence

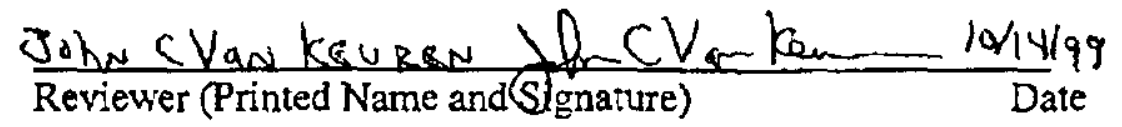


TWR-3738, Rev. 1

Preparation and Review of Calculation Notes
Manual

Desk Instruction

Page

Effective Date
HNF-2353

4.3, Rev. 0

8 of 8

June 10, 1999

\section{ATTACHMENT C}

\section{CHECKLIST FOR TECHNICAL PEER REVIEW}

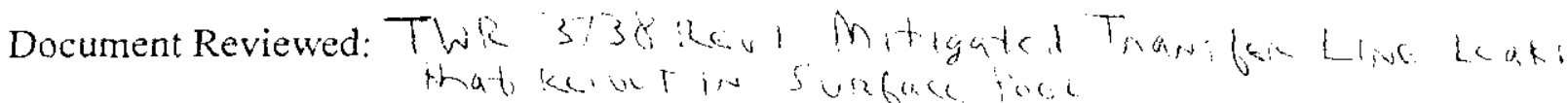

Scope of Review: C strize Dar. w w ot

Yes No NA

K] [ ] [ ] Previous reviews are complete and cover the analysis, up to the scope of this review, with no gaps.

[X] [ ] [ ] Problem is completely defined.

X] [] [ ] Accident scenarios are developed in a clear and logical manner.

[ [] [ ] Necessary assumptions are explicitly stated and supported.

(X] [ ] [ ] Computer codes and data files are documented.

Q] [] [] Data used in calculations are explicitly stated.

A [] [] Data were checked for consistency with original source information as applicable.

[] [] [ [ Mathematical derivations were checked including dimensional consistency of results.

(x] [ ] [ ] Models are appropriate and were used within their established range of validity or adequate justification was provided for use outside their established range of validity.

M [] [] Spreadsheet results and all hand calculations were verified.

$X[][]$ Software input is correct and consistent with the document reviewed.

A [ ] [ ] Software output is consistent with the input and with the results reported in the document reviewed.

A [] [] Limits/criteria/guidelines applied to the analysis results are appropriate and referenced. Limits/criteria/guidelines were checked against references.

Q [ ] [ ] Safety margins are consistent with good engineering practices.

$\triangle[][]$ Conclusions are consistent with analytical results and applicable limits.

级 [] [] Results and conclusions address all points in the purpose.

X

The document was prepared in accordance with HNF-2353, Section 4.3, Attachment B, "Calculation Note Format and Preparation Instructions".

X] II II Concurrence

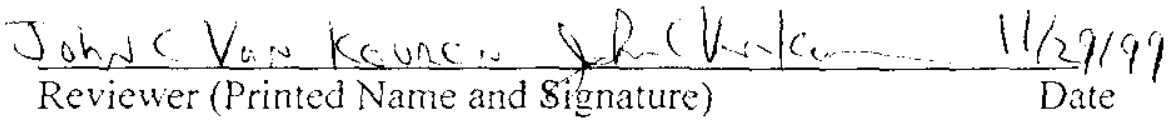

